INTERNATIONAL BULLETIN OF BACTERIOLOGICAL NOMENCLATURE AND T AXONOMY

Volume 10 No. 2 (Supplement) April 15, 1960 pp.87-192

\author{
THE NOMENCLATURAL STATUS OF THE \\ GENERIC NAMES OF THE ACTINOMYCETALES ${ }^{1,2}$
}

Erwin F. Lessel, Jr.

Iowa State University

of Science and Technology

Ames, Iowa

\title{
INTRODUCTION
}

In the past there has been a tendency in systematic bacteriology to stress descriptions, diagnostic techniques and taxonomy with relatively little, if any, emphasis on nomenclature. The extent to which this is true is indicated by St. John, who, as recently as 1958 (pp. 6-7), stated that there were no useful publications available to the student of bacteriological nomenclature. Actually, the necessity for such aid was recognized as far back as 1930 by the first International Microbiological Congress (Paris), which appointed a Committee on Bacteriological Nomenclature to investigate the special needs of bacteriology. From this committee a Judicial Commission was elected and authorized toprepare a code of nomenclature for the bacteria (New York, 1939). The proposed code was approved by the International Committee and the International Congress (Copenhagen, 1947) and was published in the Journal of Bacteriology (55:287306 (1948)), the Journal of General Microbiology (3: 444$462(1949))$ and in various journals in translations into French, German, Spanish and Japanese. At the International Congress of Microbiology held in Rio de Janeiro (1950) the International Committee directed a revision of the code by the Judicial Commission. The revision was finally approved for publication by the International Committee and the Plenary Session (Rome, 1953). The International Code of Nomenclature of Bacteria and Viruses was subsequently

1 Journal Paper No. J-3821 of the Iowa Agricultural and Home Economics Experiment Station, Ames, Iowa, Project No. 151 .

2 Supported in part by grants from the Bacteriology and Mycology Study Section, Division of Research Grants, National Institutes of Health; from the Committee on Taxonomy, Society of American Bacteriologists; and from the Bergey's Manual Trust. 
published in book form in 1958. Complete and detailedhistorical accounts of the development of the Bacteriological Code are given in the Foreword to the Code (1958, v-xvi) and by Buchanan (1959, 27-31).

An enormous amount of descriptive information has accumulated on the organisms (actinomycetes) in the bacterial order Actinomycetales. Much of this information, however, is confused and difficult to assess as to its value. In an effort to clarify this situation, significant studies are in progress by two groups of bacteriologists, one a Subcommittee on the Actinomycetes sponsored by the Committee on Bacterial Taxonomy of the Society of American Bacteriologists, the other a Subcommittee on Taxonomy of the Actinomycetes sponsored by the International Committee on Bacteriological Nomenclature of the International Association of Microbiological Societies. Liaison is facilitated by the fact that Dr. David Gottlieb is chairman of each of these subcommittees. Among the aims of these subcommittees are: the designation and maintenance of type cultures, the selection and evaluation of the criteria most useful in describing and segregating the taxa, the standardization of the techniques used to determine these criteria, and the establishment of greater uniformity and stability in nomenclature. The present contribution is designed to facilitate the selection of the correct names of the taxa of the Actinomycetales of generic rank.

In order to make this study as comprehensive as possible, two categories of generic names have been included:

1) Names of those genera which have been placed by one or more authors with the actinomycetes, irrespective of current taxonomic concepts, and

2) Names of those genera which have never been included with the actinomycetes but in which have been placed one or more species which have variously been regarded as actinomycetes (e.g. Bacillus Cohn).

Morphological similarities of the actinomycetes with the filamentous fungi are readily apparent, and the question of the relationship of the actinomycetes to the bacteria on the one hand and the fungi on the other hand has provoked considerable thought and discussion. Increasingly, however, the tendency has been to regard the actinomycetes as more closely related to the bacteria than to the true fungi; this viewpoint is substantiated by the fact that the following 
characteristics are common to the actinomycetes and the bacteria but not to the fungi: 1) a minute diameter (0.5 1. $0 \mu$ ) of hyphae or cells, 2) the absence of true nuclei, 3) composition of the cell wall (Cummins and Harris 1958, 184) and 4) phage sensitivity; furthermore, there is a rather complete series of intergrading forms (the nocardiae, the mycobacteria and the corynebacteria) between the actinomycetes and the Eubacteriales but no such series connecting the actinomycetes with the fungi. There is also a practical aspect to the question of whether the actinomycetes are to be included with the true fungi or with the bacteria. The nomenclature of the true fungi is governed by the rules of the Botanical Code, not those of the Bacteriological Code. The Botanical Code (Art. 34) states:

In order to be validly published, a name of a new taxon of recent plants, the bacteria and algae excepted, published on or after 1 Jan. 1935 must be accompanied by a Latin diagnosis or by reference to a previously and effectively published Latin diagnosis.

Inasmuch as all true fungi are included in the requirement for Latin diagnosis, it follows that if the actinomycetes are included with the fungi, only those names that conform to the statement just cited are validly published and have standing in nomenclature. Assignment of the actinomycetes to the fungi would invalidate a large number of names due to lack of a Latin diagnosis and would create much confusion. As indicated above, the evidence of the bacterial rather than the fungal relationship of the actinomycetes is quite convincing. In the evaluation of generic names in the present contribution, such bacterial relationship is assumed, and the International Code of Nomenclature of Bacteria and Viruses (First Reprinting, 1959) has been followed.

For each generic name included in this study the original literature was consulted, insofar as it could be made available, and the validity of publication and legitimacy of the names evaluated. In addition, the following information has been included: synonymy and homonymy, the name of the type species and its basionym (the epithet-bringing synonym), comments of special interest and a statement indicating the relationship of the genus to the actinomycetes. 
The synonymy includes only objective synonyms (names based on the same type species), subjective synonyms (names based on different type species but arbitrarily regarded as synonyms) being excluded. In many instances the relationship of the genus to the actinomycetes is indicated merely by the listing of selected synonyms of a species in the genus.

Only those names which have been validly published have standing in nomenclature. In order to be validly published the name of a taxon must be both effectively published and accompanied by a description of the taxon or by a reference to a previously and effectively published description of it. In order for a publication to be effective, it must consist of printed matter made available to the general public or to bacteriological institutions either by sale or distribution. Additional requirements for the valid publication of names are many, some of the more important being that the name must be accepted by the author who published it (see Carteria Musgrave et al.), that the name must not be merely mentioned incidentally (see Thermoactinomyces Tsiklinsky 1898), that it must not merely be cited as a synonym (see Cohnistreptothrix Pinoy 1911) nor merely mention the subordinate taxa included in it (see Eubacterium Janke). A further qualification for the valid publication of a generic name is that there must be a description of one or more species or a citation to a previously and effectively published description of one or more species included in the genus (see Jensenia Bisset and Moore 1949, Phleobacterium Pribram and Streptococcus Cohn); if described species are included in the genus, the species must be named or identified with a previously named species (see Coccothrix Lutz).

Of those names which have been validly published, and therefore have standing in nomenclature, only legitimate names are acceptable. According to the Bacteriological Code (Principle 5):

a) the word "name," unless otherwise indicated, means a name which has been validly published, whether legitimate or illegitimate,

b) a "legitimate name" ... is one that is in accordance with the rules,

c) an "illegitimate name" ... is one that is contrary to the rules, and

d) the "correct name" of a taxon with a particular circumscription, position, and ' is the name which must be adopted for it under $t_{1}$. rules. 
Examples of generic names which are illegitimate are later synonyms (see Brevistreptothrix Lignières, Discomyces Rivolta and Pionnothrix Wollenweber), later homonyms (see Discomyces Pinoy and Morax, Mycococcus Krassilnikov and Streptothrix Cohn), names proposed as substitute names (see Actinocladothrix Affanassieff and Schulz, Cory-

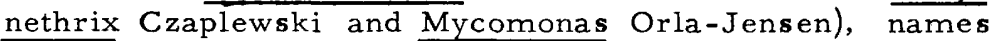
based on impure cultures (see Malleomyces Hallier and Mycococcus Bokor) and subgeneric names which included the type species of the genus but which did not bear the name of the genus (see Pseudospira Trevisan, Thermobacterium (Orla-Jensen) Pederson and Zymosarcina (Smit) $\overline{\text { Breed) }}$.

On the basis of careful studies of the pertinent literature, the apparent nomenclatural status of each generic name in the following list has been evaluated. In the use of this list, certain rules of the Bacteriological Code must be borne in mind. For example, when two or more generic names compete for recognition as the correct name of a genus, the earliest legitima te name has priority and must be adopted. A case in point (as yet not resolved) involves the names Microbispora Nonomura and Ohara (type species $\underline{M}$. rosea) and Waksmania Lechevalier and Lechevalier (type species W. rosea). A comparison of the generic and specific descriptions suggests the probability that these genericnames were proposed for the same genus and are therefore synonyms. Which name is the correct name under the rules must be determined by priority of publication. The date of publication is customarily designated as the date on which the article wherein the name was proposed was placed in the mail or was otherwise made available to bacteriologists. Both Microbispora and Waksmania were published in August of 1957; however, the exact dates of publication of these names have not been definitely established, and which name has priority has not, at this writing, been determined.

Whenever two or more genera are united into a single genus or whenever a genus is divided into two or more genera, the selection of the correct name, or the need for proposing a new generic name, is determined by the rules of priority and homonymy. 


\section{LIST OF GENERIC NAMES}

Achorion Remak 1845, 205. (A genus of fungi.)

Achorium Clements and Shear 1931, 409 (a later orthographic variant (Appendix B, (c)l, Bact. Code) of Achorion Remak).

Validly published.

Legitimate.

Type species (monotypy): Achorion schoenleini Remak 1845, 205.

Relationship to actinomycetes:

Achorion repens (Eklund) Guéguen 1904, 147.

Nocardia repens (Eklund) Vuillemin 1931, 124.

Actinomyces repens (Eklund) Nannizzi 1934, 42.

Achorium Clements and Shear 1931, 409 (a later orthographic variant (Appendix B, (c)l, Bact. Code) of Achorion Remak, g. ‥).

Actinobacillus Brumpt 1910, 849.

not Actinobacillus Beijerinck 1913, 197.

L' actinobacille, Lignières and Spitz 1902a, 27;1902c, 487; 1903, 454; $1904,454$.

Actinobacilo, Lignières and Spitz 1902b, 181.

Aktinobacill, Lignières and Spitz 1902d, 946.

$L^{\prime}$ actinobacille, Nocard and Leclainche 1903, 375.

Aktinobacillus, Lignières and Spitz (according to Porcher 1903, 781).

Validly published.

Legitimate.

Type species (monotypy): Actinobacillus lignieresi Brumpt 1910, 849.

Comments: Lignières and Spitz (1902a, 27 ; 1902 c, 487; 1903, 454; $1904,454)$ described under the vernacular name (French) "l'actinobacille" an organism which caused lesions in cattle and sheep; this vernacular name was also used by Nocard and Leclainche $(1903,375)$. Lignières and Spitz (1902b, 181; 1902d, 946) also applied the vernacular names (Spanish and Russian, respectively) "actinobacilo" and "aktinobacill" to this organism. Porcher (1903, 781), in abstracting one of Lignières and Spitz' earlier papers (1902c), used the term "Aktinobacillus" in making the transition from the French to the German vernacular.

Lehmann and Neumann $(1907,578)$ incorrectly cited "Actinobacillus Lignières and Spitz (C.B.R. XXXII. 781)." This reference is to Porcher's abstract $(1903,781)$ and not to Lignières and Spitz, whose papers reveal no such use of "Actinobacillus." Furthermore, this generic name as cited by Lehmann and Neumann was not validly published for they did not introduce it as a new name (Rule $12 \mathrm{c}(3)$ ).

Bergey et al. (1934, 559), and later Hagan (1939, 553; 1948, 556), also incorrectly cited, in synonymy, "Actinobacillus, Lignières and Spitz, Cent. f. Bakt., I Abt., Orig., 35, 1903 [sic], 294." As stated above, examination of Lignières and Spitz' papers fails to reveal the use of any such seientific name. 
The first valid publication of the generic name Actinobacillus was by Brumpt $(1910,849)$ in the statement:

". . la troisième, qui ne semble pas encore avoir été signalée chez l'Homme, se présente en culture sous la forme coccobacillaire et strepto-bacillaire; elle constitue 1'Actinobacille de

Lignières (Actinobacillus Lignieresi E. Brumpt, 1910)."

The combined description of genus and species given by Brumpt-se présente en culture sous la forme cocco-bacillaire et strepto-bacillaire-and his reference to a previous description-l'Actinobacille de Lignières-are both quite brief. Nontheless Brumpt's reference to a previous description is entirely adequate, and the generic and specific names are validly published (Rule 12a(2)). The adequacy of Brumpt ${ }^{8} \mathrm{~s}$ reference is substantiated by the fact that the numerous authors (e. g. Enlows 1920, 12; Winslow et al. 1920, 197; Buchanan 1925, 158; Ford 1927, 185; Topley and Wilson 1929, 253; Hagan 1943, 315; Hauduroy et a1. 1953, 4; Haupt 1957, 414) who have recognized Actinobacillus Brumpt 1910 have, in most cases, given complete and accurate references to the pertinent papers by Lignières and Spitz.

Relationship to actinomycetes: This genus was placed in the actinomycetes by Bergey et al. in the first four editions of Bergey's Manual of Determinative Bacteriology and in the subfamily Leptotrichioideae Baldacci, family Mycobacteriaceae, order Actinomycetales by Baldacci $(1939,94)$.

Actinobacillus lignieresi Brumpt 1910, 849.

Nocardia lignieresi (B rumpt) Chalmers and Christopherson 1916, 242 .

Discomyces lignieresi (Brumpt) Brumpt 1922, 993.

Proactinomyces lignieresi (Brumpt) Krassilnikov 1941, 76.

Actinobacillus Beijerinck 1913, 197.

not Actinobacillus Brumpt $1910,849$.

Carboxydomonas Orla-Jensen 1909, 311.

Validly published.

Illegitimate.

Type species (monotypy): Actinobacillus oligocarbophilus (Beijerinck and van Delden) Beijerinck 1913, 198. (Basionym: Bacillus oligocarbophilus Beijerinck and van Delden 1903,33.)

Comments: A later synonym of Carboxydomonas Orla-Jensen and a later homonym of Actinobacillus Brumpt, hence illegitimate (Rule 24a and $\mathrm{d}$ ).

The ascription of Actinobacillus oligocarbophilus to Beijerinck conforms to Opinion 20(4), Internat1. Bull. Bact. Nomen. and Taxon. 8 : 162 (1958).

Relationship to actinomycetes: Beijerinck (1913, 197 and 198; 1914. 109) placed this genus in the actinomycetes.

Actinobacillus oligocarbophilus (Beijerinck and van Delden)

Beijerinck 19 13,198 .

Actinomyces oligocarbophilus (Beijerinck and van Delden)

Lantzsch $1922,309$. 
Proactinomyces oligocarbophilus (Beijerinck and van Delden)

Krassilnikov 1941, 72 .

Actinobacillus paulotrophus Beijerinck 1914, 97.

Actinomyces (Streptothrix) paulotrophus Beijerinck 1914, 97.

Proactinomyces paulotrophus (Beijerinck) Krassilnikov 1941, 74.

Actinobacterium Haass 1906, 185.

not Actinobacterium (according to Reitz 1906, 731).

Brevistreptothrix Lignieres 1924, 19.

Validity of publication (see "Comments" below).

Legitimate.

Type species (monotypy): Actinobacterium israelli (Kruse) Sampietro

1908, 408. (Basionym: Streptothrix israeli Kruse 1896a, 56.)

Comments: The nomenclatural status of this generic name is not entirely clear. Haass described two anaerobic strains of actinomycetes, isolated from cases of human actinomycosis, which he designated as "Actinomyces Klinik I und II." Haass (1906, 185) suggested that these two strains be placed in a group of the actinomycetes together with: "... die wahrscheinlich identisch von Wolff und Is rael, Silberschmidt, Wright u. A. beschriebenen Erreger menschlicher Aktinomykose..." Haass proposed the generic name Actinobacterium for this group but gave no specific epithet (no binary combination). Sampietro(1908, 408) recognized the genus Actinobacterium, ascribed it to. Haass, and named and described Actinobacterium israëli var. spitzi. This constituted a varietal designation in the species Streptothrix is raeli Kruse.

The relationship between Haass' strains and the organism described by Sampietro is explained as follows:

1. Haass' descriptions of his strains of Actinomyces (Klinik I und II) resemble those of anaerobic, pathogenic actinomycetes previously described; he noted, without giving a species name, the probable identity of his strains with the Wolff-Israel organism (Streptothrix israeli Kruse).

2. The generic name Actinobacterium was recognized by Sampietro and ascribed to Haass.

3. Sampietro named and described a variety of Streptothrix israeli under the name Actinobacterium israeli var. spitzi; he did not use the binary combination Actinobacterium is raëli.

4. The proposal by Sampietro of the variety Actinobacterium israeli var. spitzi apparently assumed the simultaneous recognition of a second subspecies of an Actinobacterium is raèlias Actinobacterium israelli var. israëli. Rule 7 of the Bacteriological Code reads, in part:

"If the species is divided into subspecies, the subspecific epithet of the subspecies containing the type of the species must be the same as that of the species."

This may be interpreted to mean that Sampietro indirectly recognized an Actinobacterium is raéli var. is raëli and, concomitantly, the species A. israelli. Article 25 of the Botanical Code has 
pertinence; it reads, in part:

"Valid publication of a subordinate taxon which does not include the nomenclatural type of the higher taxon automatically circumscribes a second taxon of the same rank which has as its nomenclatural type the type of the higher taxon and bears the same epithet."

Application of this botanical rule would seem to justify the recognition of Actinobacterium israelli (Kruse) Sampietroas the type species of Actinobacterium Haass.

5. The generic name Actinobacterium Haas s was accepted by Pun-

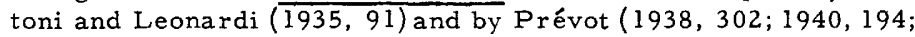
1948, 250); the latter author placed this genus in the order Actinobacteriales Prévot, class Actinomycetales. It was also accepted by Hauduroy et al. $(195 \overline{3,6)}$ and by Gastinel et al. (1957, 653).

Sampietro named the organism originally described, but not named, by Haass. A proposal for the validation of the publication of the generic name Actinobacterium Haass made to the Judicial Commission may be advisable since this name has been accepted by those authors who separate the Wolff-Israel organism (Actinomyces is raelii (Kruse) Lachner-Sandoval) from the genus Actinomyces Harz.

Relationship to actinomycetes: See "Comments" above.

Actinobacterium (according to Reitz 1906, 731).

not Actinobacterium Haas s 1906, 185.

Not validly published.

Comments: Notproposed as a generic name (Rule $12 c(3))$. Reitz mentioned incidentally the combination "Actinobacterium lactis viscosum (Duclaux)," apparently the result of confusion with Actinobacter Duclaux (1882, 110).

Relationship to actinomycetes: A homonym of Actinobacterium Haass, $\underline{\mathrm{q}}$.

Actinocladothrix Affanassieff and Schulz 1889, 684 .

Actinomyces Harz $1877,485$.

not Actinomyce Meyen 1827, 442. (A genus of fungi.)

Discomyces Rivolta 1878, 208. not Discomyces Pinoy and Morax 1911, 98.

Aërothrix Wollenwebex 1921, 27. (Subgenus)

Validly published.

Illegitimate.

Type species (Rule 9c (3)(d)): The same as that of Actinomyces Harz, i. e. Actinomyces bovis Harz 1877, 485; also see $\operatorname{Harz} 1879,133$.

Comments: Illegitimate because proposed as a substitute name to replace Actinomyces Harz (Rule 23). The statement made by Affanassieff and Schulz $(1889,684)$ is: "Auf Grund der biologischen Eigenschaften schlagen Verfasser vor, die Actinomyces als Actinocladothrix zu bezeichnen." 
Numerous authors have ascribed the name Actinocladothrix to Affanassieff. Gasperini $(1892,183)$ cited "Actinocladothrix bovis (?) o Bacterium actinoclad., Affanassiew" as a synonym of Actinomyces bovis Harz; Levy $(1899,2)$ stated: "Affanassieff nannte ihn [Actinomyces Harz] direkt Actinocladothrix;" Schlegel (1913, 303) cited "Actinocladothrix Affanassieff [1888, 84]" in synonymy; Bergey et a1. (1939, 840) and Waksman and Henrici (1948, 925) cited "Actinocladothrix Afanassiev, St. Petersb. med. Wochnschr., 4, 1887, $323^{\prime \prime}$ in synonymy. However, an examination of Affanassieff's papers reveals the proposal of the species name Bacterium actinocladothrix (1888, 84) but not of the generic name Actinocladothrix; the first proposal of the latter name was made by Affanassieff and Schulz (1889, 684).

Relationship to actinomycetes: A synonym of Actinomyces Harz, q.

Actinococcus Kützing 1843, 177. (A genus of algae.)

not Actinococcus Beijerinck 1913, 197.

Validly published.

Legitimate.

Type species (monotypy): Actinococcus roseus (Suhr) Kützing 1843, 177. (Basionym: Rivularia rosea Suhr; quoted from Kützing 1843, 177.)

Relationship to actinomycetes: An earlier homonym of Actinococcus Beijerinck, q. $\underline{v}$.

Actinococcus Beijerinck 1913, 197.

not Actinococcus Kützing 1843, 177.

Validly published.

Illegitimate.

Type species (monotypy): Actinococcus cyaneus (Schroeter) Beijerinck 1913, 198. (Basionym: Bacteridium cyaneum Schroeter 1872, 126.)

Comments: A later homonym of the algal generic name Actinococcus Kützing, hence illegitimate (Rule 24d).

Relationship to actinomycetes: Placed by Beijerinck (1913, 197 and 198) in the actinomycetes.

Actinococcus cyaneus (Schroeter) Beijerinck 1913, 198. Proactinomyces cyaneus (Schroeter) Krassilnikov 1938a, 164.

Actinoides Pribram 1933, 38 (apparently a typographical error for Actinomycoides Pribram, q. $-\underline{-}$.).

Actinoidomyces Pribram 1929, 375.

Actinomycoides Pribram 1933, 12.

Actinoides Pribram 1933, 38 (apparently a typographical error for Actinomycoides Pribram).

Validly published.

Legitimate.

Type species (original designation): Actinoidomyces actinoides (Smith) 
Pribram 1929, 376. (Basionym: Bacillus actinoides Smith 1918,342.) Relationship to actinomycetes: Placed by Pribram (1929, 375) in the tribe Actinoidomycetaceae Pribram, family Actinomycetaceae. Actinoidomyces actinoides (Smith) Pribram 1929, 376. Actinomyces actinoides (Smith) Bergey et al. 1923, 346. Actinobacillus actinoides (Smith) Topley and Wilson 1929, 256. Proactinomyces actinoides (Smith) Krassilnikov 1941, 65.

Actinomyce Meyen 1827, 442. (A genus of fungi.)

not Actinomyces Harz 1877, 485.

Validly published.

Legitimate.

Type species (monotypy): Actinomyce horkelii Meyen 1827, 442.

Comments: Some authors have incorrectly rejected Actinomyces Harz as an orthographic variant, hence to be treated as a later homonym, of Actinomyce Meyen (but see "Comments" under Actinomyces Harz).

Actinomyces Harz 1877, 485.

not Actinomyce Meyen 1827, 442. (A genus of fungi.)

Discomyces Rivolta $1878,208$.

Actinocladothrix Affanassieff and Schulz 1889, 684.

Aërothrix Wollenweber 1921, 27. (Subgenus)

Validly published.

Legitimate.

Type species (monotypy): Actinomyces bovis Harz 1877, 485; also see Harz 1879, 133.

Comments: This generic name has been incorrectly rejected by some authors as either a later homonym or a later orthographic variant of the fungus generic name Actinomyce Meyen (1827). Those who have rejected Actinomyces Harz as a later homonym of Actinomyce Meyen have incorrectly cited the latter as (or have indicated it to be) Actinomyces Meyen.

Perroncito (1879b, 35) quoted Garovaglio who in turn quoted Pirotta as follows: "Doch hebt Dr. Pirotta gelegentlich hervor, dass der von Dr. Harz diesem Coniomyceten beigelegte generische Name [Actinomyces Harz] geändert werden sollte, weil bereits früher der gleiche Name von Mayen (Linnaea, II. S. 433. 1827) auf einvon dem Harzschen durchaus verschiedenes pflanzliches Gebilde (Nostoc?) angewendet worden war."

DeToni and Trevisan (1889, 927) cited: "Actinomyces Harz ...nec Meyen."

Blanchard (1896, 857) cited: "Actinomyces bovis Harz (non Actinomyces J. Meyen, 1827)."

Musgrave et al. $(1908,458)$ stated: "Meyen ... described a fungus under the name Actinomyces [!] horkelii. Bollinger ... published an account of a disease in cattle caused by a vegetable organism which was carefully described and named Actinomyces by Harz..., 
who at this time probably did not know of the previous occupation of the name by Meyen."

Chalmers and Christopherson (1916, 228) similarly stated: "This fungus was examined by Harz $(1877-78)$, who gave it the name Actinomyces bovis, but, most unfortunately, this generic name cannot stand, because, unbeknown to Harz, it had already been used by Meyen (1827) for a fungus which he called Actinomyces [!] horkelii..."

Castellani and Chalmers (1919, 1041) cited: "Genus Nocardia Toni and Trevisan, 1889. Synonyms. - Actinomyces Harz, 1877, nec Meyen, 1829."

On the other hand, Merrill and Wade $(1919,65)$ have rejected Actinomyces Harz as a later orthographic variant, hence to be treated as a later homonym, of Actinomyce Meyen; they state:

"It is to be noted that Meyen used the name Actinomyce. While by some the use of this form might conceivably be argued not to invalidate Actinomyces, the derivation of the two is identical, and the argument cannot hold."

However, Actinomyce and Actinomyces are etymologically distinct, are not likely to cause confusion and are not to be regarded as orthographic variants, hence are not to be treated as homonyms:

a. The second component of the generic name Actinomyce Meyen is myce. There are two Greek words with this spelling. The first, my $c \bar{e}$, is a feminine noun meaning the lowing or bellowing of oxen or the bleating of sheep; the second, my̆cé, also a feminine noun, means fungus.

b. The second component of the generic name Actinomyces Harz is my̆cēs, my̆cētis, a masculine noun meaning fungus.

c. The stem of myce is myc-; the stem of myces is mycet -

d. Inasmuch as Actinomyce and Actinomyces have different spellings and are based upon different Greek stems, they are to be regarded neither as orthographic variants nor as homonyms.

e. Actinomyce and Actinomyces do not give rise to confusion when used as stems in the formation of names of higher taxa. For example, the name of a family based on Actinomyce would be Actinomycaceae; the name of a family based on Actinornyces is Actinomycetaceae.

f. Danger of confusion is further minimized by the fact that the genus Actinomyce Meyen was placed by its author in the fungus tribe Hydrotremellinae Meyen; the genus Actinomyces Harz is commonly placed in the bacterial family Actinomycetaceae Buchanan.

Puntoni and-Leonardi $(1935,91)$ and Negroni $(1953,19)$ have proposed the designation of Actinomyces albus (Rossi Doria) Krainsky 1914,662 and 683 as the type species; this is not consonant with Rule $9 c(1)$.

Krassilnikov (1949, 112) ascribed this rneric name to Waksman and Henrici 1943. An examination of the 1 r or (1943, 337-341) re- 
veals that they used the name Actinomyces Harz and did not propose Actinomyces as a new generic name.

Relationship to actinomycetes: Actinomyces Harz is the type genus of the family Actinomycetaceae Buchanan which, in turn, is the type family of the order Actinomycetales Buchanan. The term "actinomycetes" is itself derived from actinomycet-, the stem of Actinomyces, and is a vernacular name of organisms in the order Actinomycetales.

Actinomyceton Vuillemin 1931. 159.

Not valldly published.

Type species: None designated.

Comments: This name was introduced by Vuillemin $(1931,159)$ as follows:

"Il est indiqué d'ajouter aux genres médicaux Madurella et Gliomyceton un genre Actinomyceton pour les grains formés de Nocardia, de Pasteurella, de Sclerothrix et, en général, de Champignons appartenant à la famille des Microsiphonées. Le Nocardia Bovis [sic], agent de $l^{\prime}$ actinomycose classique, tient le premier rang, avec le $\mathrm{N}$. Thibiergei."

No binary combinations using the generic name Actinomyceton were given in the text by Vuillemin; however he did list thirteen such combinations in an index of organisms (p. 285). The specific epithets of twelve of these thirteen combinations were also used by Vuillemin $(1931,284)$ in combination with either one or the other of the names Nocardia, Pasteurella and Sclerothrix; these three genera were recognized by Vuillemin.

It is difficult to determine what Vuillemin meant by a "medical genus." Inasmuch as the species concerned appeared in two different classifications under two different names (e.g. Nocardia bovis and Actinomyceton bovis), it appears that Vuillemin intended to separate the granular from the non-granular form of a species and place these in separate genera.

Relationship to actinomycetes: See "Comments" above.

Actinomycoides Pribram 1933, 12.

Actinoidomyces Pribram 1929, 375.

Actinoides Pribram 1933, 38 (apparently a typographical error for Actinomycoides Pribram).

Validly published.

Illegitimate.

Type species (original designation): Actinomycoides actinoides (Smith) Pribram 1933, 12. (Basionym: Bacillus actinoides Smith 1918, 342.)

Comments: A later synonym of Actinoidomyces Pribram (Rule 24a).

Relationship to actinomycetes: Placed by Pribram $(1933,12)$ in the family Actinomycetaceae. 
Actinophyta Serbinov 1922 (according to Serbinov 1925, 542). (Class)

Validity of publication not yet determined.

Comments: This name was used by Serbinov to designate a class of bacteria. Krassilnikov (1949, 44) and Waksman (1959b, 49) have indicated this to be a generic name.

Relationship to actinomycetes: Regarded by Krassilnikov $(1949,44)$ as a synonym of Actinomyces Harz, and mentioned by Waksman $(1959 b, 49)$ as a generic designation in the actinomycetes.

Actinoplanes Couch 1950, 89.

Validly published.

Legitimate.

Type species (monotypy): Actinoplanes philippinensis Couch 1950, 89.

Type strain: ATCC No. 12427; strain P-15, Univ. No. Carolina.

Comments: Couch $(1950,88)$ stated that the question of the relationship of this genus to Myceliochytrium Johansen 1945 was raisedby Karling. Couch concluded that Myceliochytrium was based either on a mixed culture consisting of a chytrid and an actinomycete (hence an illegitimate name: Rule $24 \mathrm{~g}$ ) or on a pure culture of a fungus quite distinct from the organisms which Couch placed in Actinoplanes (in which case the genus Myceliochytrium would be placed among the fungt instead of the bacteria).

Relationship to actinomycetes: Placed by Couch $(1950,87)$ in the Actinomycetales.

Aërothrix Wollenweber 1921, 27. (Subgenus)

Actinomyces Harz 1877, 485.

not Actinomyce Meyen 1827, 442. (A genus of fungi.)

Discomyces Rivolta 1878, 208.

not Discomyces Pinoy and Morax 1911, 98.

Actinocladothrix Affanassieff and Schulz 1889, 684.

Validly published.

Illegitimate.

Type species (Rule 24a): Actinomyces (Aërothrix) bovis Harz 1877, 485; also see Harz 1879, 133.

Comments: Wollenweber recognized the genus Actinomyces Harz with two subgenera: Pionnothrix and Aërothrix. Many species were included by Wollenweber in Aërothrix, one of them being Actinomyces bovis Harz, the nomenclatural type of the genus. When a genus is divided into subgenera, that subgenus which includes the type of the genusmust bear the same name as the genus (Rule 5c). The subgeneric name Aërothrix is a later synonym of the generic name Actinomyces Harz both being based on the same type species.

Relationship to actinomycetes: See "Comments" above. 
Agrobacterium Conn 1942, 359.

Validly published.

Legitimate.

Type species (original designation): Agrobacterium tumefaciens

(Smith and Townsend) Conn 1942, 359. (Basionym: Bacterium tumefaciens Smith and Townsend 1907, 672.)

Relationship to actinomycetes:

Agrobacterium agropyri (O'Gara) Săvulescu 1947a, 10.

Corynebacterium agropyri (O'Gara) Burkholder 1948, 395.

Agrobacterium hypertrophicans (Stahel) Săvulescu 1947a, 10.

Corynebacterium hypertrophicans (Stahel) Burkholder 1948, 398.

Agrobacterium tritici (Hutchinson) Săvulescu 1947a, 10.

Corynebacterium tritici (Hutchinson) Burkholder 1948, 400.

Alcaligenes Castellani and Chalmers 1919, 936.

Validly published.

Legitimate.

Type species (original designation): Alcaligenes faecalis Castellani and Chalmers 1919, 936.

Comments: The first name proposed for the species which has been designated as the nomenclatural type of this genus is Bacillus faecalis alcaligenes Petruschky 1896, 187; however this name is a ternary combination and therefore was not validly published (Rule $14 \mathrm{a}(1)$ ).

Relationship to actinomycetes:

Alcaligenes lipolyticus (Evans) Pacheco 1933, 9.

Mycobacterium lipolyticum (Evans) Krassilnikov 1949, 165.

Anaeromyces Castellani, Douglas and Thomson 1921, 151.

Validly published.

Legitimate.

Type species (monotypy): Anaeromyces bronchitica Castellani et al. 1921,151 .

Comments: The statement made by Castellani et al. (1921, 151) is:

"We have given, temporarily, the generic name Anaeromyces..." The publication of a name is not invalidated by an expression of taxonomic doubt (Rule 12 c(1) Note).

Relationship to actinomycetes: Castellani et al. (1921, 151) regarded this genus as being closely related to genera ordinarily included in the Actinomycetales.

Aplanobacter Smith 1905, 171.

Pollendera Trevisan $1884 \mathrm{~b}$ (according to Trevisan 1885b, 95).

(?) Bacteridium Davaine 1868, 26.

not Bacteridium Schroeter 1872 (according to Castellani and Chalmers 1919, 933).

Bacteridium (Davaine) Buchanan 1918a, 37. (Subgenus)

Validly published.

Illegitimate. 
Type species (original designation): Aplanobacter anthracis (Cohn) Smith 1905, 171. (Basionym: Bacillus anthracis Cohn 1872, 177.)

Comments: The type species of Bacteridium Davaine 1868 is indeterminate between $B$. fermenti and $B$. anthracis (Cohn) Hauduroy et al. (see "Comments" under Bacteridium Davaine). Designation of the former as type would render Aplanobacter illegitimate as a later synonym of Pollendera Trevisan, and designation of the latter would render Aplanobacter illegitimate as a later synonym of Bacteridium Davaine (Rule 24a).

Relationship to actinomycetes:

Aplanobacter insidiosum McCulloch 1925, 497.

Corynebacterium insidiosum (McCulloch) Jensen 1934, 41.

Mycobacterium insidiosum (McCulloch) Krassilnikov 1941, 102

Aplanobacter michiganense (Smith) Smith 1914, 165.

Corynebacterium michiganense (Smith) Jensen 1934, 47.

Mycobacterium michiganense (Smith) Krassilnikov 1941, 115.

Arthrobacter Fischer 1895, 141. (Nomen rejiciendum)

not Arthrobacter Conn and Dimmick 1947, 301. (Nomen conservandum)

Not validly published.

Type species: None designated.

Comments: Proposed as the name of a hypothetical genus, Arthrobacter Fischer was not validly published (Rule $12 \mathrm{c}(2)$ ). Rejected by the Judicial Commission of the International Committee on Bacteriological Nomenclature (Opinion 24, 1958 e, 171-172).

Relationship to actinomycetes: An earlier homonym of Arthrobacter

Conn and Dimmick, $\underline{g} \cdot \underline{v}$.

Arthrobacter Conn and Dimmick 1947, 301. (Nomen conservandum) not Arthrobacter Fischer 1895, 141. (Nomen rejiciendum)

Validly published.

Legitimate.

Type species (original designation): Arthrobacter globiformis (Conn) Conn and Dimmick 1947, 301. (Basionym: Bacterium globiforme Conn 1928, 6.)

Comments: Conserved by the Judicial Commission (Opinion 24, 1958e, $171-172)$.

Relationship to actinomycetes: Regarded by Krassilnikov (1949, 151) as a synonym of Mycobacterium Lehmann and Neumann. Placed by Breed $(1957,578)$ in the family Corynebacteriaceae Lehmann and Neumann.

Asterococcus Scherffel 1908, 762. (A genus of algae.)

not Asterococcus Borre1, Dujardin-Beaumetz, Jeantet and Jouan 1910, 179.

Validly published.

Legitimate.

Relationship to actinomycetes: An earlier homonym of Asterococcus Borrel et al., g. $\underline{\text {. }}$. 
Asterococcus Borrel, Dujardin-Beaumetz, Jeantet and Jouan 1910, 179. not Asterococcus Scherffel 1908, 762. (A genus of algae.)

Mycoplasma Nowak 1929, 1349. (Nomen conservandum)

Asteromyces Wroblewski $1931,105$.

Borrelomyces Turner 1935, 26.

Bovimyces Sabin 1941, 57.

Pleuropneumonia Tulasne and Brisou 1955, 237.

Validly published.

Illegitimate.

Type species (monotypy): Asterococcus mycoides Borrel et al. 1910, 179.

Comments: A later homonym of the algal generic name Asterococcus Scherffel (Rule 24d). The later synonym Mycoplasma Nowak has been placed in the list of conserved bacterial generic names by the Judicial Commission (Opinion 22, 1958c, 167).

Relationship to actinomycetes: Ledingham (1933, 408 and 409) proposed that the pleuropneumonia organism (the type species of Asterococcus Borrel et al.) be placed in the family Actinomycetaceae, order Actinomycetales, in a new, but unnamed, genus.

Asterococcus muris (de Mello and Pais) Heilman 1941, 32.

Streptothrix muris-ratti Schottmüller 1914, 87.

Nocardia muris de Mello and Pais 1918, 183.

Actinomyces muris-ratti (Schottmüller) Lieske 1921, 31.

Actinomyces muris (de Mello and Pais) Topley and Wilson 1936, 274 .

Proactinomyces muris (de Mello and Pais) Krassilnikov 1941, 76.

Asteroides Puntoni and Leonardi 1935, 92.

Validly published.

Legitimate.

Type species (original designation): Asteroides asteroides (Eppinger) Puntoni and Leonardi 1935, 92. (Basionym: Cladothrix asteröides Eppinger 1891, 309.)

Comments: The name of the type species of this genus is illegitimate as a tautonym (Rule 25c; also set the Annoatation to this Rule).

Relationship to actinomycetes: Puntoni and Leonardi (1935, 94) segregated the species Actinomyces asteroides (Eppinger) Gasperini from the genus Actinomyces Harz and designated it as the type species of their new genus, Asteroides. These two genera, along with Actinobacterium Haass, were then placed by these authors in the order Microsyphonales (sic) Vuillemin. 
Asteromyces Wroblewski 1931, 105.

Asterococcus Borrel, Dujardin-Beaumetz, Jeantet and Jouan 1910, 179 .

not Asterococcus Scherffel 1908, 762. (A genus of algae.)

Mycoplasma Nowak 1929, 1349. (Nomen conservandum)

Borrelomyces Turner 1935, 26.

Bovimyces Sabin 1941, 57.

Pleuropneumonia Tulasne and Brisou 1955, 237.

Validly published.

Illegitimate.

Type species (monotypy): Asteromyces peripneumoniae-bovis Wroblewski 1931, 105.

Comments: A later synonym of Mycoplasma Nowak (Rule 24a).

The specific epithet "peripneumoniae-bovis" of the type species of this genus is illegitimate (Rule 24b); the earliest legitimate specific epithet for this species is "mycoides" (from Asterococcus mycoides Borrel et al. 1910, 179).

Bacillus Cohn 1872, 175. (Nomen conservandum)

Validly published.

Legitimate.

Type species (subsequent designation: Opinion A, Nomenclature Committee and Plenary Congress of the Second Internatl. Congress for Microbiol., Procoedings, London, 1936, 28): Bacillus subtilis (Ehrenberg) Cohn 1872, 175. (Basionym: Vibrio subtilis Ehrenberg 1835, 279.)

Type strain: Marburg; ATCC No. 6051.

Comments: The International Committee on Bacteriological Nomenclature ruled in Opinion A that:

a. Bacillus Cohn 1872 should be designated as a genus conservandum.

b. The type species of Bacillus should be designated as Bacillus subtilis Cohn emendavit Prazmowski 1880.

c. The type (or standard) strain should be the Marburg strain.

This Opinion was approvedby the Plenary Session of the Second International Congress of Microbiology.

Relationship to actinomycetes: Included in the Actinomycetales are numerous species which have been placed in the genus Bacillus at one time or another. A list of the names of these species would be too long for inclusion here; the following partial synonymies are given merely as examples:

Bacillus diphtheriae Flügge 1886, 225.

Corynebacterium diphtheriae (Flügge) Lehmann and Neumann $1896,350$.

Mycobacterium diphtheriae (Flügge) Krassilnikov 1941, 98 .

Bacillus farcinicus (Trevisan) Gasperini 1892, 183.

Nocardia farcinica Trevisan 1889a, 9.

Actinomyces farcinicus (Trevisan) Gasperini 1892, 222.

Proactinomyces farcinicus (Trevisan) Krassilnikov 1941, 88. 
Bacteridium Davaine 1868, 26.

not Bacteridium Schroeter 1872 (according to Castellani and Chalmers

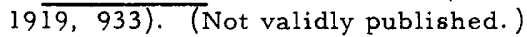

(?) Pollendera Trevisan 1884b (according to Trevisan 1885b, 95).

(?) Aplanobacter Smith 1905, 171.

Bacteridium (Davaine) Buchanan 1918a, 37. (Subgenus)

Validly published.

Legitimate.

Type species: Indeterminate.

Comments: Davaine placed six species in this genus, all of which were described and given vernacular names; only one, Bacteridium fermenti, was given a scientific name (binary combination). As the only species named, Bacteridium fermenti would appear to be the nomenclatural type (see Rule 9c(1)). However, internal evidence indicates that the genus was based on the organism causing anthrax, as noted by Cohn (1872, 148), Macé (1897, 485) and Smith (1905, 158). Smith (p. 159) stated that:

"Davaine used this word long ago in a perfectly plain and legitimate way to separate the non-motile from the motile forms, and the organism, which he studied most carefully as the type of his new genus, is that which was only some years afterwards designated Bacillus anthracis, namely in 1872, when Cohn formed his new genus Bacillus. If the genus Bacteridium is to stand at all as a bacterial genus, it must be used for Bacillus anthracis and its congeners, and it is an eminently proper name for these organisms, provided bacteriologists can bring themselves to think, with Fischer, that this name is not too close to the fungous genus Bacteridium Kunze... The writer does not share this opinion."

Smith (1905, 171) then proposed Aplanobacter as a new generic name and stated that:

"The type of the genus, in the family Bacteriaceae, is that organism causing anthrax and most commonly known in literature as Bacillus anthracis Cohn."

Other authors who have indicated the anthrax organism to be the type species of this genus are Enlows (1920, 20), Prévot (1948, 21 22) and Hauduroy et al. (1953, 85).

Buchanan (19i8a, 37 ) proposed Bacteridium Davaine be designated as a subgenus of Bacillus Cohn, with Bacillus (Bacteridium) anthracis Cohn as the type species.

The determination of the type species of this genus is a difficult problem, one which probably should be referred to the Judicial Commission.

Relationship to actinomycetes: A homonym of Bacteridium Schroeter, q. v. 
Bacteridium Schroeter 1872 (according to Castellani and Chalmers กิ919, 933).

not Bacteridium Davaine 1868, 26.

not Bacteridium (Davaine) Buchanan 1918a, 37. (Subgenus)

Micrococcus Cohn 1872, 151.

Not validly published.

Type species (original designation): Bacteridium prodigiosum (Ehrenberg) Schroeter 1872, 110. (Basionym: Monas prodigiosa Ehrenberg 1848,354 .)

Comments: Schroeter (1872, 110-126) placed a number of species of non-motile, pigment-producing bacteria, most of them cocci, in the genis Bacteridium. Cohn (1872, 148) later stated that Schroeter's organisms were completely different from the non-motile rods of anthrax which Davaine had placed in his genus Bacteridium. Cohn $(1872,153-157)$ then transferred five of Schroete $\mathrm{r}^{\prime} \mathrm{s}$ organisms, including Bacteridium prodigiosum, to his newly proposed (1872, 151) genus Micrococcus. Castellani and Chalmers (1919, 933) subsequently recognized the genus Bacteridium Schroeter (also see Enlows $1920,20)$ and designated the type species as Bacteridium prodigiosum (Ehrenberg) Schroeter. Such designation rendered Bacteridium Schroeter an earlier synonym of Micrococcus Cohn; however the former generic name was not validly published because there is no indication that Schroeter intended to introduce it as a new name (Rule $12 \mathrm{c}(3))$.

Relationship to actinomycetes: A synonym of Micrococcus Cohn, q. v. Bacteridium cyaneum Schroeter 1872, 126.

Actinococcus cyaneus (Schroeter) Beijerinck 1913, 198.

Bacteridium (Davaine) Buchanan 1918a, 37. (Subgenus)

not Bacteridium Schroeter 1872 (according to Castellani and Chalmers

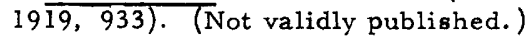

Pollendera Trevisan $1884 \mathrm{~b}$ (according to Trevisan 1885b, 95).

(?) Bacteridium Davaine 1868, 26.

Aplanobacter Smith 1905, 171.

Validly published.

Legitimacy indeterminate.

Type species (original designation): Bacillus (Bacteridium) anthracis Cohn 1872, 177.

Comments: The legitimacy of this subgeneric name is dependent upon whether the type species of Bacteridium Davaine is B. fermenti Davaine or $\mathbf{B}$. anthracis (Cohn) Hauduroy et al. (see "Comments" under Bacteridium Davaine). Designation of the former as type species would render Bacteridium (Davaine) Buchanan illegitimate as a later synonym of Pollendera Trevisan (Rule 24a); designation of the latter would render Bacteridium (Davaine) Buchanan legitimate.

Relationship to actinomycetes: A synonym of Aplanobacter Smith, q. also see the homonym Bacteridium Schroetor. 
Bacterium Ehrenberg 1828, 8. (Nomen rejiciendum)

Validly published.

Illegitimate.

Type species (monotypy): Bacterium triloculare Ehrenberg 1828, 8 .

Comments: Illegitimate as a nomen dubium (Rule 24f). The generic name Bacterium Ehrenberg was rejected in an Opinion by the Judicial Commission (Opinion 4 (Revised), 1954a, 142).

Relationship to actinomycetes: Included in the Actinomycetales are numerous species which have been placed in the genus Bacterium at one time or another. A list of the names of these species would be too long for inclusion here; the following partial synonymies are given merely as examples:

Bacterium nocardi Migula 1900, 345.

Nocardia farcinica Trevisan 1889a, 9.

Streptothrix farcinica (Trevisan) Rossi Doria 1891, 424.

Actinomyces farcinicus (Trevisan) Gasperini 1892, 222.

Bacterium diphtheriae (Flugge) Migula 1900, 499.

Corynebacterium diphtheriae (Flügge) Lehmann and Neumann

1896,350 .

Mycobacterium diphtheriae (Flügge) Krassilnikov 1941, 98.

Bacteroides Castellani and Chalmers 1919, 959.

Ristella Prevot $1938,290$.

Validly published.

Legitimate.

Type species (original designation): Bacteroides fragilis (Veillon and

Zuber) Castellani and Chalmers 1919, 959. (Basionym: Bacillus

fragilis Veillon and Zuber 1898, 536.)

Relationship to actinomycetes:

Bacteroides avidus Eggerth 1935, 289.

Corynebacterium avidum (Eggerth) Prévot 1938, 304.

Mycobacterium avidum (Eggerth) Krassilnikov 1949, 167.

Bacteroides catenaformis Eggerth 1935, 286.

Mycobacterium catenoformis (sic) (Eggerth) Krassilnikov 1949, 166. Bacteroides cornutus (Distaso) Castellani and Chalmers 1919, 960.

Mycobacterium cornutum (Distaso) Krassilnikov 1949, 166.

Bacteroides limosus Eggerth 1935, 290.

Mycobacterium limosum (Eggerth) Krassilnikov 1949, 166.

Betabacterium Orla-Jensen 1919, 175.

Betabacterium (Orla-Jensen) Pederson 1948, 350. (Subgenus)

Validly published.

Legitimate.

Type species (subsequent designation: Kluyver and van Niel 1936, 401):

Betabacterium breve Orla-Jensen 1919, 178.

Comments: One of the three species originally placed in this genus by Orla-Jensen was Betabacterium caucasicum. According to Orla- 
Jensen (1919, 175 and 176) this species was previously known"... under the name of Bacterium caucasicum..." and exhibited "...unstained parts, which have previously been regarded as spores ( spora)." It is clearly evident that Orla-Jensen regarded Betabacterium caucasicum as identical with Dispora caucasica Kern, the prototype of Lactobacillus caucasicus (Beijerinck) Beijerinck, the type species of the genus Lactobacillus Beijerinck. Therefore, because the genus Betabacterium Orla-Jensen 1919, when originally proposed, included the type species of the genus Lactobacillus Beijerinck 1901, Betabacterium would be a later synonym of Lactobacillus, hence illegitimate (Rule 24a). However, Pederson (1948, 351) stated that: "Beijerinck was apparently the first to have isolated a lactobacillus from kefir in pure culture and to have given a sufficiently complete description to make reidentification possible. It should be noted that from the characters given, this could not have been the same species as that isolated later from kefir by v. Freudenreich (loc. cit.) and Orla-Jensen (loc. cit.)." According to Pederson's conclusion, Betabacterium caucasicum Orla-Jensen is not identical with Lactobacillus caucasicus (Beijerinck) Beijerinck, and Betabacterium Orla-Jensen is therefore a legitimate name.

Relationship to actinomycetes: Placed by Kluyver and van Niel (1936, 391 ) in the tribe Corynebacterieae of the family Mycobacteriaceae. Krassilnikov (1949, 217) transferred Betabacterium breve OrlaJensen, the type species of this genus, to the genus Lactobacterium Krassilnikov, $\underline{q} . \underline{v}$.

Betabacterium (Orla-Jensen) Pederson 1948, 350. (Subgenus)

Betabacterium Orla-Jensen 1919, 175.

Validly published.

Legitimate.

Type species (Rule 5c): Lactobacillus brevis (Orla-Jensen) Bergey et al. 1934, 312. (Basionym: Betabacterium breve Orla-Jensen $\overline{19} \overline{19}, 178$.

Relationship to actinomycetes: A subgenus of Lactobacillus Beijerinck, q.. . ; also see Betabacterium Orla-Jensen.

Bifidibacterium Prévot 1938, 301 (a later orthographic variant (Rule 27, Notes 2 and $6 \mathrm{c}$ ) of Bifidobacterium Orla-Jensen, q. $\underline{\mathrm{v}}$.).

Bifidobacterium Orla-Jensen 1924, 472.

Tissieria Pribram 1929, 376.

Bifidibacterium Prévot 1938, 301 (a later orthographic variant (Rule 27 , Notes 2 and $6 \mathrm{c}$ ) of Bifidobacterium Orla-Jensen).

Validly published.

Legitimate.

Type species (monotypy): Bifidobacterium bifidum (Tissier) OrlaJensen 1924, 472. (Basionym: Bacillus bifidus Tissier 1900, 85.) 
Comments: The ascription of Bifidobacterium bifidum to OrlaJensen conforms to Opinion 20(4), Internatl. Bull. Bact. Nomen, and Taxon. 8:162 (1958).

Relationship to actinomycetes: Placed by Prévot (1938, 305; 1940a, 17; $1948,44 ; 1953,137)$ in the actinomycetes; also see Tissieria Pribram.

Borrelomyces Turner 1935, 26.

Asterococcus Borre1, Dujardin-Beaumetz, Jeantet and Jouan 1910, 179.

not Asterococcus Scherffel 1908, 762. (A genus of algae.)

Mycoplasma Nowak 1929, 1349. (Nomen conservandum)

Asteromyces Wroblewski 1931, 105.

Bovimyces Sabin $1941,57$.

Pleuropneumonia Tulasne and Brisou 1955, 237.

Validly published.

Illegitimate.

Type species (original designation): Borrelomyces peripneumoniae (Nowak) Turner 1935, 26. (Basionym: Mycoplasma peripneumoniae Nowak 1929, 1349.)

Comments: Illegitimate as a later synonym of Mycoplasma Nowak (Rule 24a). However a preliminary statement has been issued by the Editorial Board of the Judicial Commission (1955, 13-20) suggesting the conservation of either Mycoplasma Nowak or Borrelomyces Turner, the conserved name then to replace the illegitimate name Asterococcus Borrel et al. (a decision is pending).

The specific epithet "peripneumoniae" of the type species of this genus is illegitimate (Rule 24b); the earliest legitimate specific epithet is "myco"ides" (from Asterococcus mycoides Borrel et al. 1910, 179).

Relationship to actinomycetes: A synonym of Asterococcus Borrel et al., g. $\underline{\text { v. }}$

Bovimyces Sabin 1941, 57.

Asterococcus Borrel, Dujardin-Beaumetz, Jeantet and Jouan 1910, 179.

not Asterococcus Scherffel 1908, 762.(A genus of algae.)

Mycoplasma Nowak 1929, 1349. (Nomen conservandum)

Asteromyces Wroblewski $1931,105$.

Borrelomyces Turner 1935, 26.

Pleuropneumonia Tulasne and Brisou 1955, 237.

Validly published.

Illegitimate.

Type species (monotypy): Bovimyces pleuropneumoniae Sabin 1941, 57. Comments: Illegitimate as a later synonym of Mycoplasma Nowak (Rule 24a).

The specific epithet "pleuropneumoniae" of the type species of this genus is illegitimate (Rule 24b); the earliest legitimate specific epithet is "mycoides" (from Asterococcus mycoijdes Borrel et al. 1910, 179). 
Relationship to actinomycetes: A synonym of Asterococcus Borrel et al. , g. $\underline{\text { v. }}$

Brevibacterium Breed 1953, 13.

Validly published.

Legitimate.

Type species (original designation): Brevibacterium linens (Weigmann) Breed 1953, 13. (Basionym: Bacterium linens Weigmann 1910, 422.)

Relationship to actinomycetes:

Brevibacterium linens (Weigmann) Breed 1953, 13.

Mycobacterium linens (Weigmann) Krassilnikov 1949, 175.

Brevibacterium erythrogenes (Lehmann and Neumann) Breed 1953, 13.

Corynebacterium erythrogenes (Lehmann and Neumann) Kisskalt and Berend $1918,446$.

Mycobacterium erythrogenes (Lehmann and Neumann) Krassilnikov $1949,175$.

Brevibacterium helvolum (Zimmermann) Lochhead 1955, 118.

Corynebacterium helvolum (Zimmermann) Kisskalt and Berend 1918, 446.

not Corynebacterium helvolum Jensen 1934, 37.

Mycobacterium helvolum (Zimmermann) Krassilnikov 1941, 119.

Brevistreptothrix Lignières 1924, 19.

Actinobacterium Haass $1906,185$.

not Actinobacterium (according to Reitz 1906, 731).

Validly published.

Illegitimate.

Type species (original designation): Brevistreptothrix israelli (Kruse) Lignières 1924, 19. (Basionym: Streptothrix israëli Kruse 1896a, 56.)

Comments: Illegitimate as a later synonym of Actinobacterium Haass (Rule 24a).

Relationship to actinomycetes: A later synonym of Actinobacterium Haass, q.y.

Brucella Meyer and Shaw 1920, 173.

Validly published.

Legitimate.

Type species (subsequent designation: Evans 1923, 1946): Brucella melitensis (Hughes) Meyer and Shaw 1920, 173. (Basionym: Streptococcus melitensis Hughes 1892, 325.)

Comments: Although this name was validly published, several inconsistencies in Meyer and Shaw's text should be noted:

1) the name "'Micrococcus' melitensis" was used repeatedly,

2) the authors stated (p. 175) that: "... We therefore concur in the interpretation given by Miss Evans and demand that the generic 
name "Bacterium" be given to the causative organism of undulant or Malta fever."

3) they further stated (p. 176) that: "... On morphologic grounds the organisms of undulant fever and of infectious abortion of domesticated animals must therefore be considered as identical and must be placed together in the genus bacterium. "

4) finally they concluded (p. 184) that: "So-called "Micrococcus" melttensis appears in young cultures as a short rod and should therefore be designated as Bacterium melitensis."

The basionym of the type species of this genus was given by Hughes (1892, 325) as "streptococcus Miletensis (sic)." Later authors (e.g. Bruce 1893, 297) have corrected the specific epithet to "melitensis" (see Rule 27, Note 4).

Relationship to actinomycetes:

Brucella mallei (Zopf) Pacheco 1933, 13.

Corynebacterium mallei (Zopf) Lehmann and Neumann 1899, 366.

Mycobacterium mallei (Zopf) Migula (according to Chester 1901, 353).

Cladascus mallei (Zopf) Enderlein 1917a, 395.

Pfeifferella mallei (Zopf) Buchanan 1918a, 54.

Sclerothrix mallei (Zopf) Vuillemin 1931, 135.

Actinobacillus mallei (Zopf) Thompson 1933, 226.

Burkholderiella Săvulescu 1947b, 133.

Burkhordiella (sic) Săvulescu 1947b, 133 (for correction of spelling

(Rule 27(4)), see Săvulescu 1949, 431).

Validly published.

Legitimate.

Type species (monotypy): Burkholderiella insidiosa (McCulloch)

Savulescu 1947b, 133. (Basionym: Aplanobacter insidiosum McCulloch 1925, 497.)

Relationship to actinomycetes: Placed by Săvulescu $(1949,431)$ in the Actinomycetales.

Burkhordiella Săvulescu 1947b, 133 (corrected by Săvulescu $(1949,431$ ) to Burkholderiella, $\mathrm{g} \cdot \underline{\mathrm{v}}$. ).

Carboxydomonas Orla-Jensen 1909, 311.

Actinobacillus Beijerinck 1913, 97.

not Actinobacillus Brumpt 1910, 849 .

Validly published.

Legitimate.

Type species (monotypy): Carboxydomonas oligocarbophila (Beijerinck and van Delden) Orla-Jensen 1909, 311. (Basionym: Bacillus oligocarbophilus Beijerinck and van Delden 1903,33.)

Comments: The ascription of Carboxydomonas oligocarbophila to Orla-Jensen conforms to Opinion 20(4)(Judicial Commission, $1958 \mathrm{~b}$, 162). 
Relationship to actinomycetes:

Carboxydomonas oligocarbophila (Beijerinck and van Delden) OrlaJensen 1909, $31 \overline{1}$.

Actinobacillus oligocarbophilus (Beijerinck and van Delden)

Beijerinck 19 $13,198$.

Actinomyces oligocarbophilus (Beijerinck and van Delden) Lantzsch $1922,309$.

Proactinomyces oligocarbophilus (Beijerinck and van Delden)

Krassilnikov 1941,72 .

Streptomyces oligocarbophilus (Beijerinck and van Delden) Foster $1951,384$.

Carteria Musgrave, Clegg and Polk 1908, 470.

Garterii (sic) Musgrave et al. 1908, 470 (for correction of spelling, see Merrill and Wade 1919,61$)$.

Not validly published.

Type species: None designated.

Comments: Not accepted by its authors (Rule $12 \mathrm{c}(1)$ ) and did not meet the requirements of Rule 13.

Relationship to actinomycetes: Musgrave et al. (1908, 470), in a discussion of the status of the generic names Actinomyces, Nocardia and Streptothrix, state that: "...we have... tentatively accepted Streptothrix as the generic name of the organisms concerned... In making this decision we are fully aware of the rights of those who favor Actinomyces or Nocardia, and under the circumstances are tempted to introduce a new name (Carterii) for the genus..."

Carterii Musgrave, Clegg and Polk 1908, 470 (intended by Musgrave et al. to be Carteria, g.y.).

Catenabacterium Prévot 1938, 294.

Validly published.

Legitimate.

Type species (subsequent designation: Hauduroy et al. 1953, 124):

Catenabacterium helminthoides (Lewkowicz) Prévot 1938, 295.

(Basionym: Bacillus helminthoïles Lewkowicz 1901, 651.)

Relationship to actinomycetes:

Catenabacterium catenaforme (Eggerth) Prévot 1938, 296.

Mycobacterium catenoformis (sic) (Eggerth) Krassilnikov 1949, 166.

Cellfalcicula Winogradsky 1929, 626.

Validly published.

Legitimate.

Type species (subsequent designation: Bergey et al. 1930, 518):

Cellfalcicula viridis Winogradsky 1929, 616.

Relationship to actinomycetes: Included by Bergey et al. (1930, 495; $1934,534)$ in the family Mycobacteriaceae, order Actinomycetales. 
Cellulomonas Bergey et al. 1923, 154.

Validly published.

Legitimate.

Type species (original designation): Cellulomonas biazoteus (Kellerman et al.) Bergey et al. 1923, 156. (Basionym: Bacillus biazoteus Kellerman et al. 1913, 506.$)$

Relationship to actinomycetes:

Cellulomonas fimi (McBeth and Scales) Bergey et al. 1923, 166. Cellulomonas fima (sic) (McBeth and Scales) Bergey et a1. 1923, 166 .

Corynebacterium fimi (McBeth and Scales) Jensen 1934, 48.

Mycobacterium fimi (McBeth and Scales) Krassilnikov 1941, 120.

Cellvibrio Winogradsky 1929, 625.

Validly published.

Legitimate.

Type species (subsequent designation: Bergey et al. 1930, 517):

Cellvibrio ochraceus Winogradsky 1929, 601.

Relationship to actinomycetes: Placed by Bergey et al. (1930, 495; 1934, 534) in the family Mycobacteriaceae, order Actinomycetales.

Chainia Thirumalachar 1955, 935.

Validly published.

Legitimate.

Type species (original designation): Chainia antibiotica Thirumalachar $1955,935$.

Relationship to actinomycetes: Placed by Thirumalachar (1935, 934) in the order Actinomycetales.

Chlamydothrix Migula 1900, 1030.

Leptothrix Kutzing 1843, 198.

Detoniella Trevisan 1889b, 929.

Validly published.

Illegitimate.

Type species (subsequent designation: Enlows 1920, 27): Chlamydothrix ochracea (Leibl.) Migula 1900, 1031. (Basionym: Lyngbya ochracea Leibl., according to Kützing 1843, 198; Conferva ochracea Roth 1797 , according to de Toni and Trevisan 1889, 929.)

Comments: Illegitimate as a later synonym of Leptothrix Kutring (Rule 24a).

Relationship to actinomycetes: A synonym of Leptothrix Kutzing, $g \cdot y$.

Chromobacterium Bergonzini 1879, 39. (Nomen rejiciendum)

not Chromobacterium Bergonzini 1881, 153 . (Nomen conservandum) Cromobacterium (sic) Bergonzini $1879,39$.

Validly published.

Illegitimate.

Type species: None designated. 
Comments: Although legitimate at the time of its publication, this generic name was rejected by the Judicial Commission in favor of Chromobacterium Bergonzini 1881 (see Opinion 16, 1958a, 152).

Relationship to actinomycetes: An earlier homonym of Chromobacterium Bergonzini $188 \mathrm{l}, \mathrm{g} \cdot \underline{\mathrm{v}}$.

Chromobacterium Bergonzini 1881, 153. (Nomen conservandum) not Chromobacterium Bergonzini 1879, 39. (Nomen rejiciendum) Cromobacteriun (sic) Bergonzini $1881,153$.

Validly published.

Legitimate.

Type species (monotypy): Chromobacterium violaceum Bergonzini $1881,153$.

Type strain: ATCC No. 12472 and NCTC No. 9757 (see Opinion 16, Judicial Commission, 1958a, 152).

Comments: Although Chromobacterium Bergonzini 1881, was illegitimate at the time of its publication as a later homonym of Chromobacterium Bergonzini 1879, the former name has been conserved and the latter name rejected by the Judicial Commission(Opinion 16, 1958a, 152).

According to Sneath (1956, 66): "The exact date of Bergonzini's second paper is doubtful; the title page of the volume is dated 1881 , but there is no indication of whether it was issued in parts during 1880. The paper was read to the Society on 22nd June, 1880. Another review (Zimmermann, 1880) appeared in Section 49/50 of the Botanische Centralblatt, 1880 , but the day or month of is sue are not given on the Sections."

Relationship to actinomycetes:

Chromobacterium amethystinum (Chester) Holland 1920, 222.

Mycobacterium amethystinum (Chester) Krassilnikov 1949, 171.

Cladascus Enderlein 1917a, 395.

Validly published.

Legitimate.

Type species (original designation): Cladascus furcabilis Enderlein $1917 a, 395$.

Relationship to actinomycetes: Placed by Enderlein $(1917 \mathrm{~b}, 316)$ in the subfamily Corynobacteriinae Enderlein, family Corynobacteriidae Enderlein.

Cladochytrium Nowakowski 1876, 92. (A genus of chytrids.)

Validly published.

Type species (according to Clements and Shear 1931, 235): Cladochytrium tenue Nowakowski 1876, 92.

Relationship to actinomycetes: Fred, Baldwin and McCoy (1932, 139) and Bergey et al. $(1934,45)$ have indicated the relationship of Cladochytrium tuberculorum Vuillemin 1888. '93 to the genus:Rhizobium Frank. Rhizobium Frank is a synonym izomonas Orla-Jensen, which was placed with the actinomycetes by Ox $\overline{\text { a-Jensen }}(1909,334)$. 
Cladothrix Nuttall (according to Moquin 1849, 359). (A genus of phanerogams.)

not Cladothrix Cohn 1875, 185.

not Cladothrix Watson 1880,43 . (A genus of phanerogams.)

Not validly published.

Comments: Not validly published because it was cited as a synonym

(Bot. Code, Art. 37). Nuttall used Cladothrix lanuginosa as a manuscript or herbarium name, and Moquin subsequently cited the generic name Cladothrix Nuttall as a synonym of Section IV, Cladothrix, of the genus Alternanthera of the phanerogamic family Amarantaceae. Cladothrix Nuttall has been used as a generic name by various students of the flora of the southwestern United States.

Relationship to actinomycetes: An earlier homonym of Cladothrix Cohn, q.

Cladothrix Cohn 1875, 185.

not Cladothrix Nuttall (according to Moquin 1849, 359). (A genus of phanerogams.)

not Cladothrix Watson 1880, 43. (A genus of phanerogams.)

Validly published.

Legitimate.

Type species (monotypy): Cladothrix dichotoma Cohn 1875, 185.

Comments: The acceptance and use of Cladothrix Nuttall by various students of North American flora led Buchanan (1918c, 302) to refect Cladothrix Cohn as a later homonym; however, the name Cladothrix Nuttall was not validly published, hence Cladothrix Cohn is legitimate. Relationship to actinomycetes:

Cladothrix rubra (Kruse) Macé 1901, 1097.

Streptothrix rubra Kruse 1896a, 63.

Nocardia rubra (Kruse) Chalmers and Christopherson 1916, 265.

Discomyces ruber (Kruse) Brumpt 1922, 981 .

Cladothrix Watson 1880, 43. (A genus of phanerogams.)

not Cladothrix Nuttall (according to Moquin 1849, 359). (A genus of phanerogams.)

not Cladothrix Cohn 1875, 185.

Validly published.

Illegitimate.

Comments: Standley $(1916,69)$ noted that Cladothrix Nuttall was not validly published and that the first valid publication of Cladothrix as a generic name of flowering plants was by Watson; however, Cladothrix Watson is a later homonym of Cladothrix Cohn, hence illegitimate (Bot. Code, Art. 64(2)). Standley proposed the new generic name Tidestromia to replace Cladothrix Watson.

Relationship to actinomycetes: A later homonym of Cladothrix

Cohn, q. $\underline{\text {. }}$. 
Coccobacillus Gamaleia 1888, 167.

not Coccobâcillus Martzinovski 1911, 917. (Not validly published.)

Octopsis Trevisan 1885b, 102. (Nomen rejiciendum)

Pasteurella Trevisan 1887, 94. (Nomen conservandum)

Validly published.

Illegitimate.

Type species (monotypy): Coccobacillus avicidus Gamaleía 1888, 167.

Comments: De Toni and Trevisan (1889, 966) cited Coccobacillus zymogenes Leube (1885) in synonymy; however, an examination of Leube's paper fails to reveal any such binary combination. Bergey et al. $(1923,265)$ likewise cited a Coccobacillus avicidus Perroncito $(1879 a, 22)$ in synonymy; an examination of Perroncito's paper also fails to reveal any such binary combination. Inasmuch as both of these names were merely cited in synonymy, neither was validly published (Rule 12d). Coccobacillus was first validly published by Gamaleia $(1888,167)$.

Gamaleia (1888, 167) proposed the generic name Coccobacillus to include a single species, C. avicidus, which contained "die Hühnercholerabakterien." Trevisan (1889a, 21) regarded Gamaleia's or ganism as identical with his Pasteurella cholerae-gallinarum and apparently preferred the specific epithet avicida to cholerae-gallinarum for he renamed his organism Pasteurella avicida (Gamaleia) Trevisan. Trevisan (1889a, 21) cited Coccobacillus Gamaleia as a synonym of Pasteurella. Coccobacillus Gamaleía is illegitimate as a later synonym of the conserved generic name Pasteurella Trevisan (Rule 24a).

Relationship to actinomycetes:

Coccobacillus gibsoni Chorine 1929a, 42; also see 1929b, 1661.

Actinobacillus (?) gibsoni (Chorine) Hauduroy et al. 1953, 5.

Coccobacillus pseudo-actinomycosis polymorphus Berestneff 1898

(according to Chalmers and Christopherson 1916, 273).

Cohnistreptothrix neschezadimenki Chalmers and Christopherson $1916,273$.

Actinomyces neschczadimenki (Chalmers and Christopherson) Dodge 1935,712 .

Actinobacterium abscessus Prévot 1938, 303.

Coccobacillus ellingeri Metalnikov and Chorine 1928, 1643.

Regarded by Krassilnikov $(1949,228)$ as probably identical with

Pseudobacterium melolonthae (Paillot) Krassilnikov 1949, 228.

Coccobacillus diphtheroides Collis (according to Manteufel 1937, 308). Regarded by Breed (1948, 402 as probably belonging to the genus Corynebacterium Lehmann and Neumann.

Coccobacillus Martzinovski 1911, 917.

not Coccobacillus Gamaleïa 1888, 167.

Not validly published.

Comments: Martzinovski named an organism of the pleuropneumonia group "... coccobacillus mycöides peripr. ᄀiae." From an exam- 
ination of Martzinovski's paper it is evident that he was adopting the generic name Coccobacillus from earlier authors and was notproposing it as a newgeneric name(the firstinstance of valid publication of the generic name Coccobacillus was by Gamaleia 1888, 167). However, Dienes (1948, 1291), and later Freundt (1957, 914), incorrectly cited "Coccobacillus Martzinovski" in synonymy; names cited in this manner are not validly published (Rule 12d).

Relationship to actinomycetes: A later homonym of Coccobacillus

Gamaleia, g. v.

Coccothrix Lutz 1886, 98.

Sclerothrix Metschnikoff $1888,70$.

not Sclerothrix Kützing 1843, 229. (A genus of algae.)

not Sclerothrix Kützing 1849, 319. (A genus of algae.)

Mycobacterium Lehmann and Neumann 1896, 363.

Mycomonas Orla-Jensen 1909, 329.

Not validly published.

Type species (subsequent designation: Vuillemin 1913, 527): "Le Bacille tuberculeux de Koch," i.e. Mycobacterium tuberculosis (Zopf) Lehmann and Neumann $\overline{18} \overline{6}, \overline{363 . \text { (Basionym: Bacterium }}$ tuberculosis Zopf 1883, 67.)

Comments: Not validly published because Lutz did not use the generic name Coccothrix in a binary combination for either of the two species (leprosy bacillus and tubercle bacillus) which he included in this genus, nor did he cite a previously and effectively published description of either of these species under another name (Opinion 20(4), Judicial Commission, 1958b, 162). Unna (1887, 11) incorrectly cited "Coccothrix leprae (Lutz)" and de Toni and Trevisan (1889, 943 and 944) incorrectly cited "Coccothrix tuberculosis Lutz" and "Coccothrix leprae Lutz." Numerous later authors (e.g. Vuillemin 1913, 527; Buchanan 1925, 275; Bergey et al. 1934, 536 ; Hauduroy et al.

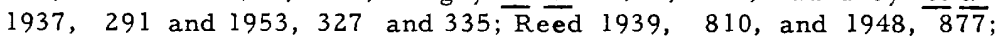
Krassilnikov 1941, 107 and 109 and 1949, 179 and 180; Hanks 1948, 882 ) have also incorrectly ascribed one or both of these names to Lutz.

Relationship to actinomycetes: A synonym of Mycobacterium Lehmann and Neumann, $\underline{q} \cdot \underline{v}$.

Cohnistreptothrix Pinoy 1911, 253.

not Cohnistreptothrix Pinoy 1913, 931.

Streptothrix Cohn 1875, 186. not Streptothrix Corda 1839, 27. (A genus of fungi.)

Discomyces Pinoy and Morax 1911, 98. not Discomyces Rivolta 1878, 208.

Not validly published.

Type species (Rule $9 c(3)(d)$ ): The same as that of Discomyces Pinoy and Morax, i.e. Discomyces foersteri (Cohn) Gedoelst 1902, 176. (Basionym: Streptothrix foersteri Cohn 1875, 186.) 
Comments: Not validly published because it was merely cited as a synonym (Rule 12d). Pinoy's statement is " $1^{\circ}$ Les discomyces (Cohnistreptothrix) correspondant réellement à la description donnée par Cohn du streptothrix Forsteri [sic], et ayant pour caractère de culture ceux de ce streptothrix. (La culture de ce parasite obtenue par M. Morax pouvait seule permettre d'être fixé à cet égard)."

Chalmers and Christopherson (1916, 240) stated that: "In 1911, for reasons presently to be set forth, Pinoy founded a new genus Cohnistreptothrix, with Israel's organism as the type species, and therefor its name becomes Cohnistreptothrix israeli (Kruse 1896)." However an examination of Pinoy's paper reveals no such designation of a type species.

Castellani and Chalmers (1919, 1063) incorrectly cited "Cohnistreptothrix is raeli (Kruse, 1896)" and Enlows (1920, 20) incorrectly cited "Streptothrix israeli Kruse" as the type species of this genus.

Relationship to actinomycetes: A synonym of Streptothrix Cohn, q. v.

Cohnistreptothrix Pinoy 1913, 931.

not Cohnistreptothrix Pinoy 1911, 253. (Not validly published.)

Streptothrix Cohn 1875, 186.

not Streptothrix Corda 1839, 27. (A genus of fungi.)

Discomyces Pinoy and Morax 1911, 98.

not Discomyces Rivolta 1878, 208.

Validly published.

Legitimate.

Type species (Rules $24 \mathrm{a}$ and $9 \mathrm{c}(3)(\mathrm{d}))$ : Cohnistreptothrix foersteri

(Cohn) Pinoy 1913, 937. (Basionym: Streptothrix foersteri Cohn 1875, 186.)

Comments: Of the earlier synonyms, Streptothrix Cohn and Discomyces Pinoy and Morax are illegitimate and Cohnistreptothrix Pinoy 1911 was not validly published; hence these names are unavailable. Cohnistreptothrix Pinoy 1913 (not Cohnistreptothrix Pinoy 1911) is the correct name of the genus which has Streptothrix foersteri Cohn as its type species.

Buchanan (1925, 404) stated that: "Pinoy (1913, p. 929) proposed that Nocardia should replace the old name Actinomyces and that a new name Cohnistreptothrix be created with Cohn's Streptothrix Foersteri as the type." However, an examination of Pinoy'spaper reveals no such designation of a type species.

Relationship to actinomycetes: Placed by Pinoy (1913, 929-938) with the actinomycetes.

Corynebacterium Lehmann and Neumann 1896, 350.

Corynethrix Czaplewski 1900, 723.

Corynemonas Orla-Jensen 1909, 329.

Corynobacterium Enderlein 1917a, 397 (a later orthographic variant (Rule 27, Notes 2 and 6c) of Corynebacterium Lehmann and Neumann). 


\section{BACTERIOLOGICAL NOMENCLATURE}

\section{AND TAXONOMY}

Validly published.

Legitimate.

Type species (subsequent designation: Winslow et a1. 1917, 555): Corynebacterium diphtheriae (Flügge) Lehmann and Neumann 1896, 350. (Basionym: Bacillus diphtheriae Flügge 1886, 225.)

Relationship to actinomycetes: Included by Lehmann and Neumann (all seven editions: 1896-1927) and by Bergey et al. (first five editions: $1923-1939$ ) in the Actinomycetales (Hyphomycetes).

Corynemonas Orla-Jensen 1909, 329.

Corynebacterium Lehmann and Neumann 1896, 350.

Corynethrix Czaplewski 1900, 723.

Corynobacterium Enderlein 1917a, 397 (a later orthographic variant (Rule 27, Notes 2 and 6c) of Corynebacterium, g.v.).

Validly published.

Illegitimate.

Type species (Rule 9c(3)(d)): The same as that of Corynebacterium Lehmann and Neumann, i.e. Corynebacterium diphtheriae (Flugge) Lehmann and Neumann $\overline{8} \overline{8} \overline{6}, \overline{350 .}$ (Basionym: Bacillus diphtheriae Flügge 1886, 225.)

Commer 4 : Illegitimate because it was proposed as a substitute name for Corynebacterium Lehmann and Neumann (Rule 23). The statement made by Orla-Jensen $(1909,329)$ is: "An die Familie Actinomycetes schliessen sichnach Lehmann und Neumann die Gattungen Corynebacterium und Mycobacterium, welche ich lieber Corynemonas und Mycomonas nenne."

Although Orla-Jensen did not designate a type species, according to Rule $9 c(3)(d)$ : "The publication of a new generic name as an avowed substitute for an earlier one does not change the type of the genus."

Relationship to actinomycetes: A synonym of Corynebacterium Lehmann and Neumann, g. v.

Corynethrix Czaplewski 1900, 723.

Corynebacterium Lehmann and Neumann 1896, 350.

Corynemonas Orla-Jensen 1909, 329.

Corynobacterium Enderlein 1917a, 397 (a later orthographic variant

(Rule 27, Notes 2 and 6c) of Corynebacterium Lehmann and Neumann, $g \cdot \underline{v}$.).

Validly published.

Illegitimate.

Type species (Rule 9c(3)(d)): The same as that of Corynebacterium Lehmann and Neumann, i.e. Corynebacterium diphtheriae (Flügge) Lehmann and Neumann 1896, 350. (Basionym: Bacillus diphtheriae Flüge 1886, 225.)

Comments: Illegitimate because it was proposed as a substitute name for Corynebacterium Lehmann and Neumann (Rule 23). The statement made by Czaplewski $(1900,723)$ is: "Ich möchte daher vorschlagen, den ersten Theil des Lehmann-Neumann'schen Namens 
, , Corynebacterien" (Coryne) beizubehalten, den zweiten (Bacterium) aber durch einen anderen Stamm (-thrix) zu ersetzen, sodass der neue Namen Corynethrix lauten würde..."

Although Czaplewski did not designate a type species, according to Rule 9c(3)(d): "The publication of a new generic name as an avowed substitute for an earlier one does not change the type of the genus." Enlows $(1920,33)$ incorrectly designated as the type species Corynethrix bovis Czaplewski 1900, 723, the only species named and described by Czaplewski.

Relationship to actinomycetes: A synonym of Corynebacterium Lehmann and Neumann, $q \cdot \underline{v}$.

Corynobacterium Enderlein 1917a, 397 (a later orthographic variant Rule 27, Notes 2 and 6c) of Corynebacterium Lehmann and Neumann, $q . \underline{v}$. ; Enderlein followed the rule of using -o- as the combining vowel in formation of a compound from two Greek words).

Cromobacterium Bergonzini 1879, 39 (the preferred spelling (Rule 27, Note 5) is Chromobacterium, $q . \underline{v}$.).

Cromobacterium Bergonzini 1881, 153 (the preferred spelling (Rule 27, Note 5) is Chromobacterium, g.v.).

Cromobacteriun (sic) Bergonziñi 1881, 153.

Cytophaga Winogradsky 1929, 624.

Validly published.

Legitimate.

Type species (subsequent designation: Bergey et al. 1930, 515):

Cytophaga hutchinsoni Winogradsky 1929, 578 .

Relationship to actinomycetes: Included by Bergey et al. (1930, 495; $1934,534)$ in the family Mycobacteriaceae of the order Actinomy cetales.

Detoniella Trevisan $1889 \mathrm{~b}, 929$.

Leptothrix Kutzing 1843, 198.

Chlamydothrix Migula 1900, 1030.

Validly published.

Illegitimate.

Type species (subsequent designation: Buchanan 1925, 289): Detoniella ochracea (Roth) Trevisan 1889b, 929. (Basionym: Conferva ochracea Roth 1797, according to de Toni and Trevisan 1889, 929; Lyngbya ochracea Leibl., according to Kützing 1843, 198.)

Comments: Illegitimate as a later synonym of Leptothrix Kutzing (Rule 24a).

Relationship to actinomycetes: A synonym of Leptothrix Kützing, q. $\underline{v}$. 


\section{BACTERIOLOGICAL NOMENCLATURE AND TAXONOMY}

Diplococcus Flügge 1886, 183.

not Diplococcus Weichselbaum 1886, 506.

Not validly published.

Type species: None designated.

Comments: Flügge (1886, 185), in his "Schlüssel für die Bestimmung der Mikrokokkenarten," listed a large number of species, five of which were named using Diplococcus as a generic name. Four of these names are ternary combinations, and one, D. subflavus, is a binary combination. In his descriptions ( $p p$. 145-148), Flügge used Micrococcus instead of Diplococcus for the generic name of these organisms, with one exception - $\underline{D}$. albicans tardissimus (p. 183). Furthermore, Flügge (p. 135) stated that:

Ferner tritt oft die Kugelgestalt nicht in deutlicher Weise hervor, wenn der Act der Theilung begonnen hat, aber die beiden Zellen noch aneinander haften, und die Abschnüring unvollendet ist (Diplococcus).

Flügge (1886) did not, in any place, indicate that he intended to introduce Diplococcus as a new generic name (Rule 12c(3)); the internal evidence suggests that Flügge merely used this name to designate a particular kind of cell aggregation.

Relationship to actinomycetes: A homonym of Diplococcus Weichselbaum, $\underline{g} \cdot \underline{v}$.

Diplococcus Weichselbaum 1886, 506.

not Diplococcus Flügge 1886, 183. (Not validly published.)

Mogallia Enderlein 1917b, 318.

Validly published.

Legitimate.

Type species (monotypy): Diplococcus pneumoniae Weichselbaum 1886, 506.

Comments: The terms "Diplococcos" and "Diplococcus" had been used by several authors prior to Weischselbaum (e. $g$. Billroth 1874,5 ; Bumm 1885, 17) to designate a particular kind of cell aggregation. These names were not used in a generic sense and therefore have no standing in nomenclature. Diplococcus Flügge 1886 was not validly published and likewise has no standing in nomenclature.

Relationship to actinomycetes: Placed by Krassilnikov (1949, 294 and 827 ) in the family Coccaceae Zopf, order Coccaceae (sic) Krassilnikov, class Actinomycetes Krassilnikov. 
Discomyces Rivolta 1878, 208.

not Discomyces Pinoy and Morax 1911, 98.

Actinomyces Harz 1877, 485.

Actinocladothrix Affanassieff and Schulz 1889, 684.

Aërothrix Wollenweber 1921, 27. (Subgenus)

Validly published.

Illegitimate.

Type species (monotypy): Discomyces bovis (Harz) Rivolta 1878, 208.

(Basionym: Actinomyces bovis Harz $\overline{1877}$, 485.)

Comments: Illegitimate because (1) it was proposed by Rivolta to replace Actinomyces Harz because he thought Actinomyces inappropriate (Rule 23) and (2) because it is a later synonym of Actinomyces (Rule 24a). Rivolta (1878, 208) states: "Il complesso dei dische che ci rappresenta, se si vuole, un micelio, non ha la forma raggiata, e per conseguenza non si può denominar raggiato o come venne detto actinomyces, e nemmeno si debbono indicare i danni o le lesioni che produce con la parola actinomicosi. Il solo nome conveniente, a mio avviso, sarebbe quello di discomyces bovis, e con la parola sarcomicosi si potrebbero indicare le lesioni che produce nel corpodel bue."

Relationship to actinomycetes: A synonym of Actinomyces Harz, q. v.

Discomyces Pinoy and Morax 1911, 98.

not Discomyces Rivolta 1878, 208.

Streptothrix Cohn 1875, 186.

not Streptothrix Corda 1839, 27. (A genus of fungi.)

Cohnistreptothrix Pinoy 1911, 253. (Not validly published.)

Cohnistreptothrix Pinoy 1913, 931.

Validly published.

Illegitimate.

Type species (Rule 24a): Discomyces foersteri (Cohn) Gedoelst 1902, 176. (Basionym: Streptothrix foersteri Cohn 1875, 186.)

Comments: Illegitimate as a later homonym of Discomyces Rivolta (Rule 24d).

Pinoy and Morax (1911, 98) rejected the generic name Streptothrix Cohn as a later homonym of Streptothrix Corda and placedorganisms ordinarily included in the former genus into two genera: 1) Discomyces, which included D. foersteri (Streptothrix foersteri Cohn), the type species of the genus Streptothrix Cohn, D. israeli Actinobacterium israelli (Kruse) Sampietro), the type species of the genus Actinobacterium Haass, and $\underline{D}$. thibiergei Ravaut and Pinoy, and 2) Nocardia, which was divided into two sections; one having as its type N. asteroides Springer 1890 ( $\underline{\mathrm{sic}}$ ), and the other having as its type $\bar{N}$. bovis (Actinomyces bovis Harz), the type species of the genera Actinomyces Harz and Discomyces Rivolta.

Inasmuch as the genus Discomyces as described by Pinoy and Morax $(1911,98)$ excluded Discomyces bovis (Harz) Rivolta, the type species of Discomyces Rivolta, the former authors were in error in using 
the name Discomyces for the group of organisms they listed (Rule 17c). The earliest name for this group is Streptothrix Cohn, which, however, is illegitimate, hence unavailable. Pinoy (1911, 253) later proposed Cohnistreptothrix as a synonym of Discomyces Pinoy and Morax; as such Cohnistreptothrix was not validly published, and likewise is unavailable. Pinoy (1913, 931) still later validly published the generic name Cohnistreptothrix, and this name is then the correct name of the genus which has Streptothrix foersteri Cohn as its type species.

Relationship to actinomycetes: A synonym of Streptothrix Cohn, $q \cdot \underline{v}$.

Distasoa Pribram 1929, 375.

Validly published.

Legitimate.

Type species (original designation): Distasoa bullosa (Distaso) Pribram 1929, 376. (Basionym: Bacillus bullosus Distaso 1912, 443.)

Relationship to actinomycetes: Included by Pribram in the family Mycobacteriaceae, order Mycobacteriales.

Eisenbergia Enderlein 1917b, 315.

Proteus Hauser $1885,12$.

not Proteus Müller 1786, 9. (A genus of protozoa.)

Validly published.

Legitimacy questionable.

Type species (original designation): Eisenbergia vulgaris (Hauser)

Enderlein 1917b, 315. (Basionym: Proteus vulgaris Hauser 1885, 12.)

Comments: A later synonym of Proteus Hauser(Rule 24a). However the legitimacy of Proteus Hauser is questionable, and the legitimacy of Eisenbergia Enderlein is dependent upon the status of Proteus Hauser.

Relationship to actinomycetes: Placed by Enderlein (1917b, 315) in the subfamily Eisenbergiinae Enderlein, family Carynobasteriidae Enderlein.

Epidermidophyton Lang 1879, 263. (A genus of fungi.)

Epidermophytum Clements and Shear 1931, 410. (A genus of fungi.) not Epidermophyton Mégnin 1881, 405. (A genus of fungi.)

Validly published (Bot. Code, Art. 36).

Relationship to actinomycetes:

Epidermophyton (sic) sp. Lang 1879 (quoted from Nannizzi 1934, 42). Nocardia repens (Eklund) Vuillemin 1931, 124.

Actinomyces repens (Eklund) Nannizzi 1934, 42.

Epidermophyton Mégnin 1881, 405. (A genus of fungi.)

not Epidermophytum Clements and Shear 1931, 410. (A genus of fungi.)

Validly published.

Legitimate.

Type species (monotypy): Epidermophyton gallinae Mégnin 1881, 405. Relationship to actinomycetes: A homonym (orthographic variant) of Epidermophytum Clements and Shear, q. 
Epidermophytum Clements and Shear 1931, 410. (A genus of fungi.) not Epidermophyton Mégnin 1881, 405. (A genus of fungi.)

Epidermidophyton Lang 1879, 263. (A genus of fungi.)

Validly published.

Type species (original designation): Epidermophytum cruris Castellani.

Comments: A later synonym of Epidermidophyton Lang and a later homonym (orthographic variant) of Epidermophyton Mégnin (Bot. Code, Art. 64(1) and (2)).

Relationship to actinomycetes: A synonym of Epidermidophyton Lang, $\underline{\mathrm{q}} \cdot \underline{\mathrm{v}}$.

Erysipelothrix Rosenbach 1909, 367.

Validly published.

Legitimate.

Type species (subsequent designation: Buchanan 1918a, .55): Erysipelothrix rhusiopathiae (Migula) Buchanan 1918a, 55. (Basionym: Bacterium rhusiopathiae Migula 1900, 431.)

Comments: The first scientific name given to the causal organism of swine erysipelas, one of the organisms originally placed in this genus by Rosenbach, was Bacillus thuillieri Trevisan (1889a, 13) followed shortly thereafter by Bacillus rhusiopathiae-suis Kitt (1893, 284) (Bacillus rhusiopathiae suis (sic) Kitt). Rosenbach named this organism Erysipelothrix porci, and Buchanan (1918a, 55) subsequently designated it as the type species of this genus under the name Erysipelothrix rhusiopathiae (Migula) Buchanan. Although the specific epithets thuillieri and rhusiopathiae-suis both clearly antedate rhusiopathiae, they have not come into common usage, and a good case could be made for their rejection or for the conservation of rhusiopathiae.

Relationship to actinomycetes: Placed by Winslow et al. (1920, 213), by Bergey et al. $(1923,338 ; 1925,346 ; 1930,45 \overline{7} \overline{1934}, 495 ; 1939$, $828)$ and by Hauduroy $(1947,87)$ in the family Actinomycetaceae, order Actinomycetales, by Baldacci $(1939,94)$ in the subfamily Leptotrichioideae, family Mycobacteriaceae, order Actinomycetales and by Prévot (1948, 26; 1953, 137) in the family Actinomycetaceae, order Actinobacteriales, class Actinomycetales (sic).

Euactinomyces Langeron $1922 b$ (according to Waksman 1940, 552).

Not validly published.

Type species: None designated.

Comments: Waksman $(1940,552)$ stated that: "A similar system was proposed by Langeron (1922), except that the aerobic forms were classified as Euactinomyces." Similarly, Baldacci $(1947,62)$ stated that: "Langeron (1923) [sic] schlägt Euactinomyces n. nomen für die faden- und sporenbildenden Species..." However, an examination of Langeron's paper fails to disclose any proposal of "Euactinomyces." The citations by Waksman and Baldacci $\vec{r}$ it constitute valid publication of the generic name Euactinomyce, , $12 \mathrm{c}(3))$. 
Relationship to actinomycetes: Mentioned by Waksman $(1940,552)$ and Baldacci $(1947,62)$ in a discussion on the classification of the actinomycetes.

Eubacterium Janke 1930, 490. (Subgenus)

not Eubacterium Prévot 1938, 294.

Not validly published.

Type species: None designated.

Comments: Proposed as a subgenus (of Bacterium Ehrenberg) which Janke divided into eleven sections named but not described; no species were listed, named or described as belonging to either the subgenus of any of its sections. According to Rule $12 \mathrm{e}$, a name of a taxon is not validly published by the mere mention of the subordinate taxa included in it. The eleven sections are: Nitrobacter, Aerobacter, Aerogenes, Escherichia, Pneumonia, Salmonella, Eberthella (with subsections Typhus and Shigella), Alcaligenes, Brucella, Pasiteurella and Hemophilus (sic).

Relationship to actinomycetes: An invalidly published earlier homonym of Eubacterium Prévot, g.v.

Eubacterium Prévot 1938, 294.

not Eubacterium Janke 1930, 490. (Subgenus)

Validly published.

Legitimate.

Type species (subsequent designation: Hauduroy et al. 1953, 248):

Eubacterium foedans (Klein) Prévot 1938, 294. TBasionym: Bacillus foedans Klein 1908, 1832.)

Comments: The earlier homonym, Eubacterium Janke, was not validly published.

Prévot (1948, 93) incorrectly cited this generic name as "Eubacterium Janke 1930 emend."

Relationship to actinomycetes:

Eubacterium limosum (Eggerth) PrEvot 1938, 295.

Mycobacterium limosum (Eggerth) Krassilnikov 1949, 166. Eubacterium tortuosum (Debono) Prévot 1938, 295.

Mycobacterium tortuosum (Debono) Krassilnikov 1949, 189.

Eumyces Battaglia 1938, 166.

Not validly published.

Comments: Battaglia (1938, 166) used "Eumyces tuberculosis" as the title of a paper wherein he contended that the characteristics of the tubercle bacillus are such that it should be included among the "Eumycètes" (the true fungi). "Eumyces," which does not appear in the body of Battaglia's paper, was not proposed as a generic name, hence it has not standing in nomenclature. Battaglia apparently used "Eumyces" as the obvious singularform of the plural "Eumycètes," and "Eumyces tuberculosis" probably was intended to mean "the tuberculosis eumycete." Reed (1948, 876 and 877 ) incorrectly cited 
"Eumyces Battaglia" as a synonym of Mycobacterium Lehmann and Neumann and "Eumyces tuberculosis Battaglia" as a synonym of Mycobacterium tuberculosis (Schroeter) Lehmann and Neumann." Hauduroy et al. (1953, 335) incorrectly cited "Eumyces tuberculosis Battaglia" as a synonym of "Mycobacterium tuberculosis var. hominis (Schroeter) Lehmann et Neumann."

Relationship to actinomycetes: Incorrectly cited by Reed (1948, 876) as a synonym of Mycobacterium Lehmann and Neumann, g. $\underline{v}$.

Flavobacter Stewart 1932, 41 (according to Breed 1948c, 427).

Flavobacterium Bergey et al. 1923, 97.

Not validly published.

Comments: There is no indication in Stewart's paper that Flavo-

bacter was proposed as a new generic name, hence it was not validly published (Rule 12c(3)); if intended as a substitute name for Flavobacterium Bergey et al., it would be illegitimate as a later synonym (Rule 24a).

Relationship to actinomycetes: See Flavobacterium Bergey et al.

Flavobacterium Bergey et al. 1923, 97.

Flavobacter Stewart 1932, 41 (according to Breed 1948c, 427). (Not validly published.)

Validly published.

Legitimate.

Type species (original designation): Flavobacterium aquatile (Frankland and Frankland) Bergey et al. 1923, 100. (Basionym: Bacillus aquatilis Frankland and Frankland 1889, 381.) Type strain: ATCC No. 11947; strain Taylor F36, Univ, of Idaho.

Relationship to actinomycetes: Baldacci (1947, 80) listed "Flavobacterium salmonicolor (den Dooren de Jong) Bergey, $193 \overline{0^{\prime \prime} \text { as a }}$ doubtful synonym of "Actinomyces melanosporeus Krainsky, 1914."

Flavobacterium helvolum (Zimmermann) Bergey et al. 1923, 114.

Corynebacterium helvolum (Zimmermann) Kisskalt and Berend $1918,446$.

not Corynebacterium helvolum Jensen 1934, 37.

Mycobacterium helvolum (Zimmermann) Krassilnikov 1941, 119.

Fusiformis Hoelling 1910, 240.

Validly published.

Legitimate.

Type species (subsequent designation: Winslow et al. 1917, 555):

Fusiformis termitidis Hoelling 1910, 240.

Comments: Kluyver and van Niel (1936, 401) incorrectly designated Fusiformis dentium Hoelling, and Prévot $(1948,25)$ incorrectly designated Fusiformis fusiformis Topley and Wilson, as the type species (Rule 9c(3)).

Relationship to actinomycetes: Placed by Winslow et al. $(1917,555)$ in the family Mycobacteriaceae, by Kluyver and van Niel $(1936,395)$ in 
the tribe Corynebactereae of the family Mycobacteriaceae, by Prévot $(1938,305)$ in the family Sphaerophoraceae, order Actinomycetales, later $(1948,44 ; 1953,137)$ in the order Actinobacteriales, class Actinomycetales (sic), and by Baldacci $(193 \overline{9,94) \text { in the subfamily Lepto- }}$ trichioideae Baldacci, family Mycobacteriaceae, order Actinomycetales.

Fusocillus Prévot 1938, 298.

Validly published.

Legitimate.

Type species (subsequent designation: Prévot 1948, 25): Fusocillus shmamini Prévot 1938, 300.

Relationship to actinomycetes: Placed by Prévot (1938, 305; 1940a, $17 ; 1948,44 ; 1953,137)$ in the actinomycetes.

Haemophilus Winslow et al. 1917, 561.

Hemophilus (sic) Winslow et al. $1917,561$.

Validly published.

Legitimate.

Type species (original designation): Haemophilus influenzae (Lehmann and Neumann) Winslow et al. 1917,561. (Basionym: Bacterium influenzae Lehmann and Neumann 1896, 187).

Relationship to actinomycetes:

Haemophilus pyogenes (Glage) Merchant 1950, 545.

Corynebacterium pyogenes (Glage) Eberson 1918, 5.

not Corynebacterium pyogenes Lewandowsky 1904, 351 and 473 . Hemophilus pyogenes (Glage) Merchant 1950, 545.

Hemophilus Winslow et al. 1917, 561 (the preferred spelling (Rule 27, Note 5) is Haemophilus, q. v.).

Heterocystia Enderlein 1917a, 397.

Validly published.

Legitimate.

Type species (original designation): Heterocystia multiformis Enderlein 1917a, 397.

Relationship to actinomycetes: Placed by Enderlein $(1917 \mathrm{~b}, 316)$ in the subfamily Corynebacteriinae Enderlein, family Corynebacteriidae Enderlein.

Indiella Brumpt 1906, 547. (A genus of fungi.)

Validly published.

Legitimate.

Type species (subsequent designation: Castellani and Chalmers 1919, 1107): Indiella mansoni Brumpt 1906, 548.

Relationship to actinomycetes:

Indiella somaliensis Brumpt 1906, 561.

Nocardia somaliensis (Brumpt) Chalmers and Christopherson 1916, 239. 
Actinomyces somaliensis (Brumpt) St. John-Brooks 1931, 75. Proactinomyces somaliensis (Brumpt) Krassilnikov 1941, 85. Streptomyces somaliensis (Brumpt) Waksman and Henrici 1948, 965.

Indiellopsis Brumpt 1913, 967. (Subgenus)

Validly published.

Legitimate.

Type species (original designation): Indiellopsis somaliensis (Brumpt) Brumpt 1913, 967. (Basionym: Indiella somaliensis Brumpt 1906, 561.)

Comments: The ascription of the combination Indiellopsis somaliensis to Brumpt $(1913,967)$ conforms to Opinion 20(4)(Judicial Commis sion, 1958b, 162).

Relationship to actinomycetes: A subgenus of Discomyces Rivolta, $q \cdot \underline{y}$. Indiellopsis somaliensis (Brumpt) Brumpt 1913, 967.

Nocardia somaliensis (Brumpt) Chalmers and Christopherson 1916, 239.

Actinomyces somaliensis (Brumpt) St. John-Brooks 1931, 75.

Proactinomyces somaliensis (Brumpt) Krassilnikov 1941, 85.

Streptomyces somaliensis (Brumpt) Waksman and Henrici 1948, 965.

Jensenia Bisset and Moore 1949, 389.

not Jensenia Bisset and Moore 1950, 280.

Not validly published.

Comments: Bisset and Moore (1950, 280) stated that: "It has been brought to our attention that in the absence of a type species the new genus Jensenia proposed in our recent paper (Bisset \& Moore, 1949) is invalid according to the international rules of bacteriological nomenclature..." However, such a requirement for the valid publication of a generic name does not exist in bacteriological nomenclature. This generic name was not validly published because no species were named or described as belonging to the genus (Rule 13).

Relationship to actinomycetes: Placed by Bisset and Moore (1949, 390) in the family Actinomycetaceae, order Actinomycetales.

Jensenia Bisset and Moore 1950, 280.

not Jensenia Bisset and Moore 1949, 389. (Not validly published.)

Validly published.

Legitimate.

Type species (original designation): Jensenia canicruria Bisset and Moore 1950, 280.

Comments: The earlier homonym, Jensenia Bisset and Moore 1949, was not validly published because no species were named or described as belonging to the genus (Rule 13); the later homonym, Jensenia Bisset and Moore 1950, is therefore a legitimate name.

Relationship to actinomycetes: Placed by Bisset and Moore (1950, 280) in the family Actinomycetaceae, order Actinomycetales. 
Lactobacterium van Steenberge 1920, 806.

Lactobacterium Krassilnikov 1949, 208.

Saccharobacillus van Laer 1892 (?), 4.

Validly published.

Illegitimate.

Type species (Rule 24a): Lactobacterium pastorianum (van Laer) van Steenberge 1920, 806. (Basionym: Saccharobacillus pastorianus van Laer 1892 (?), 4.)

Comments: Illegitimate as a later synonym of Saccharobacillus van Laer (Rule 24a).

Relationship to actinomycetes: An earlier homonym of Lactobacterium Krassilnikov, g.v.

Lactobacterium Krassilnikov 1949, 208.

Lactobacterium van Steenberge 1920, 806.

Saccharobacillus van Laer 1892 (?), 4.

Validly published.

Illegitimate.

Type species (Rule 24a): Lactobacterium pastorianum (van Laer) Krassilnikov 1949, 219. (Basionym: Saccharobacillus pastorianus van Laer 1892 (?), 4.)

Comments: The generic name Lactobacterium, type species L. pastorianum, was proposed by van Steenberge in 1920. Krassilnikov (1949, 208), apparently unaware of Lactobacterium van Steenberge, subsequently recognized the genus Lactobacterium, making no mention at all of van Steenberge. The following statement by Krassilnikov, freely translated from the Russian, could be construed as meaning that he independently proposed Lactobacterium as a generic name: "The name Lactobacillus, given by Beijerinck in 1901, does not, at the present time, conform to the generally accepted principles of systematics; therefore it is considered reasonable to substitute the name Lactobacterium for it. This name emphasizes the relationship of these organisms with the non-sporeforming bacteria."

Krassilnikov did not designate a type species for this genus, but in it he included the type species of the following genera: Saccharobacillus van Laer 1892 (?) (Lactobacterium van Steenberge 1920), Lactobacillus Beijerinck 190 1, Caseobacterium Orla-Jensen 1919, 160, Betabacterium Orla-Jensen 1919, 175 and Bifidobacterium OrlaJensen 1924. Consequently the type species of Lactobacterium Krassilnikov is Lactobacterium pastorianum (van Laer) Krassilnikov even though Krassilnikov regarded Lactobacterium as a substitute name for Lactobacillus Beijerinck (we Rule 9c(3)(d)).

There results, therefore, the unique situation whereby the same generic name, with the same type species, was independently proposed by two different authors. Lactobacterium Krassilnikov 1949 is identical in every respect with Lactobacterium van Steenberge 1920 and is illegitimate as a later synonym of Saccharobacillus van Laer (Rule 24a). 
Relationship to actinomycetes: Placed by Krassilnikov (1949, 208 and 827 ) in the family Mycobacteriaceae, order Mycobacteriales, class Actinomycetes.

Leptothrix Kützing 1843, 198.

Detoniella Trevisan $1889 \mathrm{~b}, 929$.

Chlamydothrix Migula 1900, 1030.

Validly published.

Legitimate.

Type species (subsequent designation by many authors, according to Enlows 1920, 52): Leptothrix ochracea (Leibl.) Kützing 1843, 198. (Basionym: Lyngbya ochracea Leibl., according to Kützing 1843, 198; Conferva ochracea Roth 1797, according to de Toni and Trevisan $1889,929$. )

Relationship to actinomycetes: Chalmers and Christopherson (1916, 273) cited "Leptothrix oculorum Sorokin 1881 " as a synonym of "Cohnistreptothrix foersteri(Cohn 1874);" Krassilnikov (1949, 93) cited "Leptothrix oculorum Sorokin, 1884" as a synonym of "Actinomyces forsteri (Cohn)."

\section{Leptotrichia Trevisan 1879, 138. (Nomen conservandum)}

Validly published.

Legitimate.

Type species (monotypy): Leptotrichia buccalis (Robin) Trevisan 1879 , 147. (Basionym: Leptothrix buccalis Robin 1853, 345.)

Comments: The legitimacy of this name was questioned by Breed and Pederson (1948, 364), who maintained that the monotypic nomenclatural type was a nomen dubium. Subsequently this name was placed in the list of conserved names by the Judicial Commission (Judicial Commission, Opinion 13, 1954c, 152).

Relationship to actinomycetes: Placed by Winslow et al. $(1917,555)$ in the family Mycobacteriaceae, by Bergey et al. (1923, 338; 1925, 346; $1930,457 ; 1934,495 ; 1939,828)$ and by Hauduroy $(1947,87)$ in the family Actinomycetaceae, by Prévot $(1948,44 ; 1953,137)$ in the family Sphaerophoraceae, order Actinobacteriales, class Actinomycetales (sic) and by Baldacci $(1939,94)$ in the subfamily Leptotrichioideae Baldacci, family Mycobacteriaceae, order Actinomycetales.

Listerella Jahn 1906, 540. (A genus of myxomycetes.) not Listerella Pirie 1927, 164. (Nomen rejiciendum) not Listerella Cushman 1933, 36. (A genus of protozoa.) Validly published.

Legitimate.

Relationship to actinomycetes: An earlier homonym of Listerella Pirie, q. $\underline{v}$. 
Listerella Pirie 1927, 164. (Nomen rejiciendum)

not Listerella Jahn 1906, 540. (A genus of myxomycetes.)

not Listerella Cushman 1933, 36. (A genus of protozoa.)

Listeria Pirie 1940, 383. (Nomen conservandum)

not Listeria de Necker 179 1, 206. (A genus of spermatophytes.)

Validly published.

Illegitimate.

Type species (monotypy): Listerella hepatolytica Pirie 1927, 164.

Comments: Illegitimate as a later homonym of Listerella Jahn (Rule 24d). Placed in the list of rejected generic names by the Judicial Commission (Opinion 14, 1954d, 156-157).

Relationship to actinomycetes: A synonym of Listeria Pirie, g.v.

Listerella Cushman 1933, 36. (A genus of protozoa.)

not Listerella Jahn 1906, 540. (A genus of myxomycetes.)

not Listerella Pirie 1927, 164. (Nomen rejiciendum)

Validly published.

Relationship to actinomycetes: A homonym of Listerella Pirie, $\underline{q} \cdot \underline{v}$.

Listeria de Necker 1791, 206. (A genus of spermatophytes.)

not Listeria Pirie 1940, 383. (Nomen conservandum)

Validly published.

Relationship to actinomycetes: A homonym of Listeria Pirie, $\underline{q} \cdot \underline{v}$.

Listeria Pirie 1940, 383. (Nomen conservandum)

not Listeria de Necker 1791, 206. (A genus of spermatophytes.)

Listerella Pirie 1927, 164. (Nomen rejiciendum)

not Listerella Jahn 1906, 540. (A genus of myxomycetes.)

not Listerella Cushman 1933, 36. (A genus of protozoa.)

Validly published.

Legitimate.

Type species (original designation): Listeria monocytogenes (Murray et al.) Pirie 1940, 383. (Basionym: Bacterium monocytogenes $\bar{M}$ urray et a1. 1926, 408.)

Comments: Illegitimate at the time of its publication as a later homonym of Listeria de Necker (Rule 24d). Subsequently placed in the list of conserved generic names by the Judicial Commission (Opinion 12, 1954b, 151).

Relationship to actinomycetes: Placed by Breed $(1957,578)$ in the family Corynebacteriaceae.

Loefflerella Gay et al. 1935, 783.

Pfeifferella Buchanan 1918a, 54. (Nomen rejiciendum) not Pfeifferella Labbé 1899,60 . (A genus of protozoa.)

Malleomyces Pribram 1933, 11.

not Malleomyces Hallier 1870, 119.

Validly published.

Illegitimate. 
Type species (original designation): Loefflerella mallei (Zopf) Gay et al. 1935, 783. (Basionym: Bacillus mallei Zopf 1885, 89.)

Comments: Illegitimate as a later synonym of Malleomyces Pribram 1933 (Rule 24a).

Relationship to actinomycetes:

Loefflerella mallei (Zopf) Gay et al. 1935, 783.

Corynebacterium mallei (Zopf) Lehmann and Neumann 1899, 366.

Mycobacterium mallei (Zopf) Migula (according to Chester 1901. 353).

Cladascus mallei (Zopf) Enderlein 1917a, 395.

Pfeifferella mallei (Zopf) Buchanan 1918a, 54.

Actinobacillus mallei (Zopf) Thompson 1933, 226.

Loehnisium Enderlein 1925, 258.

Löhnisium (sic) Enderlein 1925, 258.

Validly published.

Fllegitimate.

Type species (original designation): "L. aceti Hans. 1894."

Comments: The organism designated by Enderlein as the type species of Loehnisium is probably identical with the type species of Acetobacter Beijerinck, and the two generic names are probably synonymous. However the description and the citation to an earlier description of the type species of Loehnisium are both inadequate, and this generic name should probably be regarded as a nomen dubium, hence illegitimate (Rule 24f). The nomenclature of the acetic-acid bacteria, which have never been placed with the actinomycetes, is so involved that an analysis is not attempted here.

Relationship to actinomycetes: Placed by Enderlein $(1925,258)$ in the subfamily Eisenbergiinae Enderlein, family Corynobacteriidae Enderlein, the latter name presumably being equivalent to Corynebacteriaceae Lehmann and Neumann.

Löhnisium Enderlein 1925, 258 (spelling corrected (Rule 27, Note 9) to Loehnisium, q. v. .).

Malleomyces Hallier 1870, 119.

not Malleomyces Pribram 1933, 11.

Validly published.

Illegitimate.

Type species: The name given by Hallier $(1870,119)$ to his (mixed) culture was Malleomyces equestris; however, such a culture cannot be regarded as the type species of a genus.

Comments: Hallier (1870, 119) named a culture Malleomyces equestris and stated that it was the cause of the disease glanders (farcy) of the horse. A study of his description of this culture makes it clearly evident that the culture was a mixture of various fungi and bacteria; consequently the name Malleomyces Hallier is illegitimate (Rule $24 \mathrm{~g}$ ).

Relationship to actinomycetes: An ear. omonym of Malleomyces Pribram, g. v. 
Malleomyces Pribram 1933, 11.

not Malleomyces Hallier $1870,119$.

Pfeifferella Buchanan 1918a, 54. (Nomen rejiciendum)

not Pfeifferella Labbé 1899, 60. (A genus of protozoa.)

Loefflerella Gay et al. 1935, 783 .

Validly published.

Illegitimate.

Type species (original designation): Malleomyces mallei (Zopf)

Pribram 1933, 11. (Basionym: Bacillus mallei Zopf 1885, 89.)

Comments: Illegitimate as a late $\bar{r}$ homonym of Malleomyces Hallier (Rule 24d). Pribram (1933, 11 and 93) used Malleomyces as the name of a genus to include three species, of which "Malleomyces mallei (Löffler) Hallier" was designated as the type species. Pribram incorrectly ascribed both the generic name and the name of the type species to Hallier; these names are correctly ascribed to Pribram (Rule 12d and its Annotation and Rule 15b).

Relationship to actinomycetes: Placed by Pribram $(1933,11)$ in the family Mycobacteriaceae, order Mycobacteriales.

Malleomyces mallei (Zopf) Pribram 1933, 11 .

Corynebacterium mallei (Zopf) Lehmann and Neumann 1899, 366. Mycobacterium mallei (Zopf) Migula (according to Chester 1901, 353).

Cladascus mallei (Zopf) Enderlein 1917a, 395.

Pfeifferella mallei (Zopf) Buchanan 1918a, 54.

Actinobacillus mallei (Zopf) Thompson 1933, 226.

Merismopedia Meyen 1839a, 440. (A genus of blue-green algae.) not Merismopedia Zopf 1885, 51.

Validly published.

Comments: Numerous authors (e. g. Kützing 1849, 471 ; Robin 1853, 331; de Toni 1907, 104) have incorrectly cited Meyen's reference as $1839 \mathrm{~b}, 67$. However, an examination of this paper reveals that it was published subsequent to the one referred to above (Meyen 1839a, 440).

Relationship to actinomycetes: An earlier homonym of Merismopedia Zopf, g.

Merismopedia Zopf 1885, 51.

not Merismopedia Meyen 1839a, 440. (A genus of blue-green algae.)

Neisseria Trevisan 1885b, 105. (Nomen conservandum)

Validly published.

Illegitimate.

Type species (monotypy): Merismopedia gonorrhoeae Zopf 1885, 54 . Comments: Illegitimate as a later homonym of Merismopedia Meyen (Rule 24d).

Relationship to actinomycetes: An earlier synonym of Neisseria Trevisan, $\underline{g} \cdot \underline{v}$. 
Microbacterium Cohn (according to Klein 1884a, 338).

not Microbacterium (according to Smith 1905, 174).

not Microbacterium Orla-Jensen 1919, 179.

Not validly published.

Comments: Cohn (1872, 146 and 167) divided the bacteria into four tribes, the second of which, Microbacteria, included a single genus, Bacterium. Klein (1884a, 338) incorrectly cited Microbacterium Cohn, apparently as a synonym of Bacterium, as follows: "BACTERIUM (Microbacterium, Cohn)." As given by Klein, Microbacterium is in the form of a generic name but cannot be regarded as validly: published: it was not proposed as a generic name (Rule $12 \mathrm{c}(3)$ ), and it was cited as a synonym (Rule 12d).

Relationship to actinomycetes: An earlier homonym of Microbacterium Orla-Jensen, g..

Microbacterium (according to Smith 1905, 174).

not Microbacterium Cohn (according to Klein 1884a, 338).

not Microbacterium Orla-Jensen 1919, 179.

Not validly published.

Comments: Smith (1905, 174) placed "Microbacterium" in a list of names he proposed for rejection. As given by Smith, Microbacterium was not validly published because it was not proposed as a generic name (Rule $12 c(3)$ ).

Relationship to actinomycetes: An earlier homonym of Microbacterium Orla-Jensen, $\underline{q} \cdot \underline{\text { v. }}$

Microbacterium Orla-Jensen 1919, 179.

not Microbacterium Cohn (according to Klein 1884a, 338).

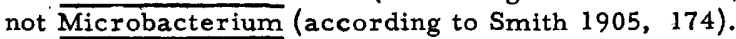

Validly published.

Legitimate.

Type species (subsequent designation: Buchanan 1925, 373): Microbacterium lacticum Orla-Jensen 1919, 179.

Comments: Klein (1884a, 338) and Smith (1905, 174) both cited the generic name Microbacterium prior to its use by Orla-Jensen (1919, 179); however, in the two former cases the name was not validly published, and the later homonym Microbacterium Orla-Jensen is therefore legitimate.

Relationship to actinomycetes: Placed by Breed $(1957,579)$ in the family Corynebacteriaceae.

Microbacterium lacticum Orla-Jensen 1919, 179.

Corynebacterium lacticum (Orla-Jensen) Jensen 1934, 50.

Microbacterium flavum Orla-Jensen $1919,181$.

Mycobacterium flavum (Orla-Jensen) Jensen 1934, 34.

Microbacterium liquefaciens Orla-Jensen 1919, 182.

Corynebacterium liquefaciens (Orla-Jensen) Jensen 1934, 49.

Mycobacterium liquefaciens (Orla-Jensen) Krassilnikov 1941, 117. 
Microbispora Nonomura and Ohara 1957 (Aug. 15), 307.

Talidy published.

Legitimate (but see Introduction, p.91).

Type species (monotypy): Microbispora rosea Nonomura and Ohara 1957, 307.

Relationship to actinomycetes: Placed by Nonomura and Ohara (1957, $307)$ in the family Streptomycetaceae.

Micrococcus Cohn 1872, 151.

Bacteridium Schroeter 1872 (according to Castellani and Chalmers $1919,933)$. (Not validly published.)

Validly published.

Legitimate.

Type species (subsequent designation: Winslow et al. 1917, 559): Micrococcus luteus (Schroeter) Cohn 1872, 153. (Basionym: Bacteridium luteum Schroeter 1872, 126.)

Relationship to actinomycetes: Placed by Krassilnikov $(1949,250)$ in the family Coccaceae, order Coccaceae (sic), class Actinomycetes.

Micromonospora Orskov 1923, 147.

Group III, Orskov 1923, 134.

Validly published.

Legitimate.

Type species (monotypy): Micromonospora chalcea (Foulerton) Orskov 1923, 147. (Basionym: Streptothrix chalcea Foulerton 1905, 1200.)

Comments: The ascription of Micromonospora chalcea to $\emptyset_{\mathrm{r} s k o v}(1923$, 147) conforms to Opinion 20(4)(Judicial Commission, 1958b, 162).

Relationship to actinomycetes: Placed by Orskov (1923, 147) with ". . the fungi which go under the generic name of Ray Fungi." Placed by Waksman and Henrici (1948, 929) and by Waksman $(1957,744$ ) in the family Streptomycetaceae, and by Krassilnikov $(1949,144)$ in the family Micromonosporaceae, order Actinomycetales, class Actinomycetes.

Micromyces Dangeard 1889, 55. (A'genus of fungi.)

not Micromyces Gruber 1893, 51 .

not Micromyces Frosch 1923, 275 (according to Freundt 1957b, 914).

Validly published.

Legitimate.

Type species (monotypy): Micromyces zygogonil Dangeard 1889, 52.

Relationship to actinomycetes: An earlier homonym of Micromyces

Gruber, $q \cdot \underline{v}$.

Micromyces Gruber 1893, 51.

not Micromyces Dangeard 1889, 55. (A genus of fungi.)

not Micromyces Frosch 1923, 275 (according to Freundt 1957b, 914).

Mikromyces (sic) Gruber 1893, 51 . 
Validly published.

Illegitimate.

Type species (monotypy): Micromyces hofmanni Gruber 1893, 35.

Comments: Illegitimate as a later homonym of Micromyces Dangeard (Rule 24d).

In the reports of the meetings of the Bacteriology Section of the VII International Congress for Hygiene and Demography, held in London in 1891, Gruber is mentioned as having demonstrated cultures of "Micromyces hoffmanni (sic)" (see Münch. med. Wochenschr. 38: 653(1891) and Cent. f. Bakt. 10:648 (1891)); Sauvageau and Radais (1892, 251) likewise mention "Micromyces" of Gruber. However such publication does not meet the requirement of effective publication by an author (in this case Gruber) as prescribed in Rule 11. Micromyces was validly published by Gruber in 1893 .

Relationship to actinomycetes: Placed by Gruber $(1893,50)$ with the hyphomycetes (actinomycetes). Regarded by Buchanan (1925, 377) and by Waksman and Henrici $(1948,925)$ as a synonym of Actinomyces Harz.

Micromyces hofmanni Gruber 1893, 35.

Actinomyces hoffmanni (sic) Gasperini 1894b, 684 .

Streptothrix hofmanni (Gruber) Kruse 1896a, 62.

Nocardia hofmanni (Gruber) Blanchard 1896, 855.

Micromyces Frosch 1923, 275 (according to Freundt 1957b, 914).

not Micromyces Dangeard 1889, 55. (A genus of fungi.)

not Micromyces Gruber 1893, 51.

Validity of publication questioned.

Comments: Freundt (1957, 914) cited Micromyces Frosch as a synonym of Mycoplasma Nowak 1929. The Editorial Board of the Judicial Commission (1955, 15) states: "It is not entirely clear whether Frosch intended to name a new genus or whether he was placing his organism in Gruber's genus Micromyces." Frosch's statement is: "Unter weiterer Berücksichtigung der früher erwähnten (1.c.) eigentümlichen Festigkeit der Kolonien, ihrer starken Kohärenz am Nährboden, die sie mit pathogenen Hefearten teilen, möchte ich den Erreger der Lungenseuche demnach zu den Sprosspilzen rechnen und ihn, nach dem Vorschlage meines Kollegen Prof. K. Neumann, Micromyces peripneumoniae bovis contag [sic] bennennen."

Microspira Schroeter 1886, 168.

Pacinia Trevisan $1885 \mathrm{a}, 83$.

Pseudospira Trevisan 1889a, 23. (Subgenus) (Nomen rejiciendum)

Validly published.

Illegitimate.

Type species (Rule 24a): Microspira comma Schroeter 1886, 168.

Comments: Illegitimate as a later synonym of Pacinia Trevisan (Rule 24a); however Pacinia has been placed by the Judicial Commission (Opinion 13, 1954c, 154) in a list of generic names whose status is indeterminate. 
Relationship to actinomycetes: A synonym of Pacinia Trevisan, $\underline{q} \cdot \underline{v}$.

Mikromyces Gruber 1893, 51 (spelling corrected to Micromyces, q.. . ; see Appendix A of the Bacteriological Code, 1958, 138).

Mogallia Enderlein 1917b, 318.

Diplococcus Weichselbaum 1886, 483. not Diplococcus Flügge 1886, 183. (Not validly published.)

Validly published.

Illegitimate.

Type species (original designation): Mogallia pneumoniae (Weichselbaum) Enderlein 1917b, 318 . (Basionym: Diplococcus pneumoniae Weichselbaum 1886, 485.)

Comments: Illegitimate as a later synonym of Diplococcus Weichselbaum (Rule 24a).

Relationship to actinomycetes: A synonym of Diplococcus Weichselbaum, $\underline{g} \cdot \underline{v}$.

Myceliochytrium Johansen 1945, 104.

Validity of publication questioned.

Type species (monotypy): Myceliochytrium fulgens Johansen 1945 , 104.

Comments: Couch $(1950,88)$ stated that the question of the relationship of this species to Actinoplanes Couch was raised by Karling. Couch concluded that the genus named Myceliochytrium was based either on a mixed culture consisting of a chytrid and an actinomycete (hence an illegitimate name: Rule $24 \mathrm{~g}$ ), or on a pure culture of a fungús quite distinct from the organisms which Couch placed in Actinoplanes (in which case the genus Myceliochytrium would be placed among the fungi instead of the bacteria).

Relationship to actinomycetes: See "Comments" above.

Mycobacterium Lehmann and Neumann 1896, 363.

Coccothrix Lutz 1886, 98. (Not validly published.)

Sclerothrix Metschnikoff 1888, 70.

not Sclerothrix Kützing 1843, 229. (A genus of algae.)

not Sclerothrix Kützing 1849, 319. (A genus of algae.)

Mycomonas Orla-Jensen 1909, 329.

Validlȳ published.

Legitimate.

Type species (subsequeñt designation: Winslow et al. 1917, 554): Mycobacterium tuberculosis (Zopf) Lehmann and Neumann 1896 , 363. (Basionym: Bacterium tuberculosis Zopf 1883, 67.)

Comments: The earlier synonym Coccothrix Lutz (q. v.) was not validly published, hence has no standing in nomenclature. Sclerothrix Metschnikoff, also an earlier synonym of Mycobacterium Lehmann and Neumann, is illegitimate as a later homonym of Sclerothrix Kützing 1849. 
Examination of Koch's classical papers on the etiology of tuberculosis (1882 and 1884) reveals the use of vernacular names (TuberkelVirus, Tuberkelbacterien and Tuberkelbacillen) but not of a Linnaean binary combination for the etiological agent of tuberculosis. Numerous authors (e.g. Lehmann and Neumann 1896, 363; Winslow et al. 1917, 554; Bergey et al. 1923, 383) have incorrectly cited "Bacillus tuberculosis Koch" as the basionym of the type species of this genus; still other authors (Reed 1939, 810 and 1948, 877; Hauduroy et al. 1937, 291 and 1953, 335) have incorrectly cited "Bacillus tuberculosis Schroeter" as the basionym.

Castellani and Chalmers $(1919,965)$ incorrectly designated Mycobacterium leprae (Hansen) Lehmann and Neumann as the type species of this genus (Rule 9c(3)).

Relationship to actinomycetes: Placed by Lehmann and Neumann. (18 6 , 363 ) in the Hyphomycetes and then, in all subsequent editions of their text, in the Actinomycetes.

Mycococcus Bokor 1930, 22.

not Mycococcus Krassilnikov 1938b, 335.

Validly published.

Illegitimate (Rule $24 \mathrm{~g}$ ).

Type species: The name given by Bokor (1930, 12) to his (mixed) culture was Mycococcus cytophagus (Hutchins on and Clayton) Bokor 1930, 12; however, such a culture cannot be regarded as the type species of a genus. (Basionym: Spirochaeta cytophaga Hutchinson and Clayton 1919, 150.)

Comments: Stanier (1940, 620-621) stated that: "Bokor (1930), claimed to have isolated a pure culture of Spirochaeta cytophaga on which he made morphological studies. As a result of these, he considered its cycle of development to be similar to that of the Actinomycetes, with which he placed it under the new name of Mycococcus cytophagus. The disparity between Bokor's findings and those of all other workers in the field, as well as the illustrations in his paper, make it apparent that he was dealing with a mixed culture of Spirochaeta cytophaga and an Actinomyces."

Relationship to actinomycetes: See "Comments" above; an earlier homonym of Mycococcus Krassilnikov, g.

Mycococcus Krassilnikov 1938b, 335.

not Mycococcus Bokor 1930, 22.

Validly published.

Illegitimate.

Type species (subsequent designation: Nellis 1957, 707): Mycococcus albus Krassilnikov 1938b, 350.

Comments: A later homonym of Mycococcus Bokor (Rule 24d). However, in conformity with Principle $1(2): "$...to avoid or to reject the use of names which may cause error or ambiguity or throw science into confusion," the conservation of the name Mycococcus Krassilnikov might well be proposed. 
Relationship to actinomycetes: Placed by Krassilnikov first (1941, 122) in the family Actinomycetaceae, order Actinomycetales and later (1949, 198 and 827) in the family Mycobacteriaceae, order Mycobacteriales, class Actinomycetes.

Mycomonas Orla-Jensen 1909, 329.

Coccothrix Lutz 1886, 98.

Sclerothrix Metschnikoff 1888, 70.

not Sclerothrix Kützing 1843, 229. (A genus of algae.)

not Sclerothrix Kützing 1849, 319. (A genus of algae.)

Mycobacterium Lehmann and Neumann 1896, 363.

Validly published.

Illegitimate.

Type species (Rule 9c(3)(d)): The same as that of Mycobacterium Lehmann and Neumann, i.e. Mycobacterium tuberculosis (Zopf)

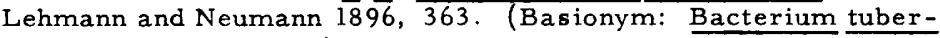
culosis Zopf 1883, 67.)

Comments: Illegitimate because it was proposed as a substitute name for Mycobacterium Lehmann and Neumann (Rule 23). The statement made by Orla-Jensen (1909, 329) is: "An die Familie Actinomycetes schliessen sich nach Lehmann und Neumann die Guttungen Corynebacterium und Mycobacterium welche ich lieber Corynemonas und Mycomonas nenne."

Although Orla-Jensen did not designate a type species, according to Rule $9 c(3)(d)$ : "The publication of a new generic name as an avowed substitute for an earlier one does not change the type of the genus."

Relationship to actinomycetes: A synonym of Mycobacteritum Lehmann and Neumann, $\underline{q} \cdot \underline{v}$.

Mycoplana Gray and Thornton 1928, 82.

Validly published.

Legitimate.

Type species (subsequent designation: Bergey et al. 1930, 516): Mycoplana dimorpha Gray and Thornton 1928, 82 .

Relationship to actinomycetes: Placed by Bergey et al. (1930, 495; $1934,534)$ in the family Mycobacteriaceae, order Actinomycetales.

Mycoplasma Nowak 1929, 1349. (Nomen conservandum)

Asterococcus Borrel, Dujardin-Beaumetz, Jeantet and Jouan 1910, 179 .

not Asterococcus Scherffel 1908, 762. (A genus of algae.)

Asteromyces Wroblewski 1931, 105.

Borrelomyces Turner 1935, 26.

Bovimyces Sabin 1941, 57.

Pleuropneumonia Tulasne and Brisou 1955, 237.

Validly published.

Legitimate. 
Type species (monotypy): Mycoplasma mycoides (Borrel et al.) Freundt 1955, 73. (Basionym: Asterococcus mycöides Borrel et al. 1910, 179.)

Comments: The earlier synonym, Asterococcus Borrel et al., is illegitimate as a later homonym of Asterococcus Scherffel (Rule 24d). Mycoplasma Nowak has been placed in the list of conservedbacterial generic names by the Judicial Commission (Opinion 22, 1958c, 167).

When originally proposed by Nowak $(1929,1349)$, the name of the type species of this genus was incorrectly given as Mycoplasmaperipneumoniae (Rule 24b). The name was corrected by Freundt (1955, 73) to Mycoplasma mycoides (Borrel et al.).

Relationship to actinomycetes: A synonym of Asterococcus Borrel et al. , q.. . ; Ledingham $(1933,408$ and 409) proposed that the pleuropneumonia organism (the type species of Mycoplasma Nowak) be placed in the family Actinomycetaceae, order Actinomycetales, in a new, but unnamed, genus.

Necrobacterium Lahelle and Thjötta 1945, 321.

Sphaerophorus Prévot 1938, 297.

not Sphaerophorus Persoon 1794, 23. (A genus of lichens.)

Validly published.

Legitimate.

Type species (monotypy): Necrobacterium necrophorum (Flügge) Lahelle and Thjötta 1945, 321 . (Basionym: Bacillus necrophorus Flügge 1886, 273.)

Comments: The earlier synonym, Sphaerophorus Prévot, is illegitimate (Rule 24d).

Relationship to actinomycetes: A synonym of Sphaerophorus Prévot, $\underline{g} \cdot \underline{v} \cdot$

Neisseria Trevisan $1885 \mathrm{~b}, 105$. (Nomen conservandum)

Merismopedia Zopf 1885, 51 .

not Merismopedia Meyen 1839a, 440. (A genus of blue-green algae.)

Validly published.

Legitimate.

Type species (monotypy): Neisseria gonorrhoeae (Zopf) Trevisan 1885b, 106. (Basionym: Merismopedia gonorrhoeae Zopf 1885, 54.)

Comments: The earlier synonym, Merismopedia Zopf, is illegitimate as a later homonym of Merismopedia Meyen (Rule 24d). Hence Neisseria Trevisan was legitimate when published; furthermore, it has been placed in the list of conserved generic names by the Judicial Commission (Opinion 13, 1954c, 153).

Relationship to actinomycetes: Placed by Krassilnikov (1949, 295 and 827 ) in the family Coccaceae, order Coccaceae (sic), class Actinomycetes. 
Nigrococcus Castellani and Chalmers 1919, 932.

Validly published.

Legitimate.

Type species (original designation): Nigrococcus nigrescens (Castellani) Castellani and Chalmers 19 19, 932. (Basionym: Micrococcus nigrescens Castellani 1911, 344.)

Relationship to actinomycetes:

Nigrococcus cyaneus (Schroeter) Castellani and Chalmers 1919, 932. Actinococcus cyaneus (Schroeter) Beijerinck 1913, 198. Proactinomyces cyaneus (Schroeter) Krassilnikov 1938a, 164.

Nitrosococcus Winogradsky 1892, 127. (Nomen conservandum) Validly published.

Legitimate.

Type species (monotypy): Nitrosococcus nitrosus (Migula) Buchanan 1925, 402. (Basionym: Micrococcus nitrosus Migula 1900, 194.)

Comments: The single species placed in this genus was described but not named by Winogradsky; hence Nitrosococcus was not validly published (Judicial Commission, Opinion 20(3), 1958 b, 161-162). According to this Opinion, the name Nitrosococcus Winogradsky 1892 became validly published when Buchanan (1918b, 180) recognized it and named Winogradsky's species Nitrosococcus americanus. Buchanan (1925, 410-402) later indicated the priority of the specific epithet in the combination Micrococcus nitrosus Migula and stated: "Apparently the correct type designation would be Nitrosococcus nitrosus (Migula)."

Placed in the list of conserved generic names, with Nitrosococcus nitrosus (Migula) Buchanan as the nomenclatural type, by the Judicial Commission (Opinion 23(4), 1958d, 170).

Relationship to actinomycetes: Placed by Krassilnikov (1949, 293 and 827 ) in the family Coccaceae, order Coccaceae (sic), class Actinomycetes.

Nocardia Trevisan 1889a, 9. (Nomen conservandum)

Pionnothrix Wollenweber 1921,27 . (Subgenus)

Validly published.

Legitimate.

Type species (subsequent designation: Judicial Commission, Opinion 13, 1954c, 153; through a clerical error the generic name Nocardia Trevisan and the name of its type species were omitted from this Opinion, but see Internatl. Bull. Bact. Nomen. and Taxon. 3:98 and 151 (1953) and Internatl. Code of Nomenclature of Bacteria and Viruses, 1958, 166): Nocardia farcinica Trevisan 1889a, 9.

Comments: When originally published by Trevisan, this genus contained the nomenclatural types of two earlier-proposed generic names. The one, "N. Förstex Trev. (Streptothrix Försteri F. Cohn, 1875), " is the type species of Streptothrix Cohn 1875 and the other, "N. Actinomyces Trev. (Actinomyces bovis Hartz [sic] ...)," is the type species of Actinomyces Harz 1877. 
Three of the five species originally included by Trevisan in the genus Nocardia were subsequently designated by various authors as the type species of this genus:

1) Nocardia foersteri (Cohn) Trevisan (1889a, 9) was designated by Vuillemin (1913, 526); such designation would make Nocardia Trevisan the legitimate name of the genus which has Streptothrix foersteri for its type species, Streptothrix Cohn 1875 being illegitimate as a later homonym of Streptothrix Corda 1839.

2) Nocardia bovis (Harz) Blanchard (1896, 857) was designated by Castellani and Chalmers (1919, 1041); such designation would make Nocardia Trevisan 1889 illegitimate as a later synonym of Actinomyces Harz 1877.

3) Nocardia farcinica Trevisan $(1889 a, 9)$ was designated by Vuille$\min (1931,119)$.

The confusion arising from the designation of several different type species for this genus was resolved by the Judicial Commiesion, which issued Opinion 13, as indicated above, conserving the generic name Nocardia Trevisan and fixing Nocardia farcinica Trevisan as the type species.

Relationship to actinomycetes: Placed by Trevisan $(1889 \mathrm{a}, 9)$ in the tribe Cladotricee (sic) Trevisan, suborder Tricogene (sic) Trevisan of the Batteriacee (sic). As indicated above, Trevisan included the type species of both Streptothrix Cohn and Actinomyces Harz in his genus Nocardia. Numerous subsequent authors have included this genus in discussions on the actinomycetes, and some (e.g. Blanchard 1896, 857; Chalmers and Christopherson 1916, 228; de $\bar{M}$ ello and Pais 1918, 143; Castellani and Chalmers 1919, 1041) have used the name Nocardia $T$ revisan in preference to Actinomyces Harz, the latter name being relegated to synonymy. Still other authors (e. g. Bergey et al. 1939,840 ) have regarded Nocardia Trevisan as a synonym of Actinomyces Harz.

Placed in the family Mycobacteriaceae by Winslow et al. (1917, 553554 ) and in the family Actinomycetaceae, order Actinomycetales by Waksman and Henrici $(\overline{1948,892})$.

Octopsis Trevisan 1885b, 102. (Nomen rejiciendum)

- Pasteurella Trevisan 1887,94. (Nomen conservandum)

Coccobacillus Gamaleía 1888, 167.

not Coccobacillus Martzinovski 1911, 917.

Validly published.

Illegitimate.

Type species (subsequent designation: Judicial Commission, Opinion 13, 1954c, 153): Octopsis cholerae-gallinarum (Zopf) Trevisan $1885 \mathrm{~b}, 102$. (Basionym: Micrococcus cholerae-gallinarum Zopf $1885,57$.

Comments: Trevisan $(1885 \mathrm{~b}, 102)$ stated that the generic name Octopsis had been proposed earlier and that the combination Octopsis equorum Trevisan appeared in an 1884 is sue of the newspaper "Cor- 


\section{AND TAXONOMY}

riere delle sera." According to Trevisan (1885b, 102): "Una tra queste minutissime specie, che un momento fui tentato riunire in un genere proprio sotto la denominazione Octopsis, è il Batterio del

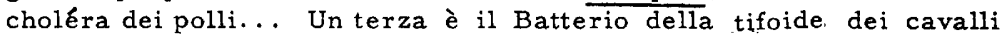
(Bacterium equorum Trevis. -Octopsis equorum Trevis., Corriere della sera, 1884 , num. 222)... It is not clear where the name Octopsis was first published; it may be that this generic name was initially proposed in the daily newspaper (1884, num.222) cited by Trevisan.

Although validly published and legitimate at the time of its publication, Octopsis Trevisan 1885 was placed in the list of rejected generic names and the later synonym Pasteurella Trevisan was placed in the list of conserved generic names by the Judicial Commission (Opinion $13,1954 \mathrm{c}, 152)$.

The ascription of the binary combination Octopsis cholerae-gallinarum (Zopf) Trevisan is in conformity with Opinion 20(4), (Judicial Commision $1958 \mathrm{~b}, 162$ ).

Oospora Wallroth 1831-33, 182. (A genus of fungi.)

Validly published.

Type species (according to Clements and Shear 1931, 388): Oospora virescens (Lk.) Wallroth.

Relationship to actinomycetes: Sauvageau and Radais (1892, 246) regarded Streptothrix Cohn and Actinomyces Harz as synonyms of Oospora Wallroth and transferred a number of actinomycetes to Oospora. Subsequent authors (e.g. Bellisari 1904, 467; Krassilnikov $1949,44)$ have sometimes attributed this generic name to Sauvageau and Radais and placed it with the actinomycetes.

Oospora bovis (Harz) Sauvageau and Radais 1892, 271.

Actinomyces bovis Harz 1877, 485; also see Harz 1879, 133. Oospora farcinica (Trevisan) Sauvageau and Radais 1892, 248. Nocardia farcinica Trevisan 1889a, 9.

Pacinia Trevisan $1885 \mathrm{a}, 83$.

Microspira Schroeter 1886, 168.

Pseudospira Trevisan 1889a, 23. (Subgenus) (Nomen rejlciendum)

Validly published.

Status indeterminate.

Type species (subsequent designation: Judicial Commission, Opinion 13,'1954c, 154): Pacinia cholerae-asiaticae (Trevisan) Trevisan 1885a, 84. (Basionym: Bacillus cholerae-asiaticae Trevisan $1884 a$ (according to Trevisan 1885a, 84).)

Comments: The relationship of this genus to Vibrio Muller (1773, 39) is not at all clear. Buchanan (1925, 522) indicated Vibrio lineola Mitler $(1773,39)$ to be the type species of the genus Vibrio; currently, however, Vibrio comma (Schroeter) Winslow et a1. (1920, 204), an organism not originally included in the genus Vibrio by Muller, is generally regarded as the type species. Designation of the latter or- 
ganism as type species would render Pacinia Trevisan 1885 illegitimate as a later synonym of Vibrio Müller 1773 (Rule 24a). According to the Editorial Board of the Judicial Commission (1953, 100): "Careful consideration should be given to the status of the generic name Vibrio in bacteriology and to the fixing up of its type species. Should Vibrio be designated as a nomen generis conservandum with type species Vibrio cholerae-asiaticae (Vibrio comma?), the Pacinia should be considered for designation as a nomen generis rejicienda [sic]." Subsequently the Judicial Commission (Opinion 13, $\overline{1954 \mathrm{c}}, 154)$ placed Pacinia Trevisan in a list of generic names of indeterminate status and designated Pacinia cholerae-asiaticae (Trevisan) Trevisan as the type species.

Trevisan (1885a, 84) listed "Vibrio Cholerae Pacini (1854)" as a synonym of Pacinia cholerae-asiaticae. However, according to Buchanan $(1925,524)$ and the Editorial Board of the Judicial Commission (1953, 99), a careful search of Pacini's paper fails to reveal this name.

Relationship to actinomycetes:

Pacinia loeffleri Trevisan 1889a, 23.

Corynebacterium diphtheriae (Flügge) Lehmann and Neumann 1896, 350 .

Pasteurella Trevisan 1887, 94. (Nomen conservandum)

Octopsis Trevisan 1885b, 102. (Nomen rejiciendum)

Coccobacillus Gamaleía 1888,167 .

not Coccobacillus Martzinovski 1911, 917.

Validly published.

Legitimate.

Type species (subsequent designation: Judicial Commission, Opinion 13, 1954c, 153): Pasteurella cholerae-gallinarum Trevisan 1887, 94.

Comments: Illegitimate, when originally published, as a later synonym of Octopsis Trevisan (Rule 24a); however the Judicial Commission placed Pasteurella Trevisan in the list of conserved generic names and Octopsis Trevisan in the list of rejected generic names (Opinion 13, loc. cit.).

Gamaleia (1888, 167) proposed the generic name Coccobacillus to include a single species, $C$. avicidus, which contained "die Hühnercholerabakterien." Trevisan (1889a, 21) regarded Gamaleia's organism as identical with his Pasteurella cholerae-gallinarum and apparently preferred the specific epithet avicida to cholerae-gallinarum for he renamed his organism Pasteurella avicida (Gamaleia) Trevisan. Trevisan $(1889 a, 21)$ cited Coccobacillus Gamaleia as a synonym of Pasteurella.

Clise (1948, 546-548) listed numerous synonyms (objective and subjective) of the type species of this genus and used multocida (from Bacterium multocidum Lehmann and Neumann 1899, 196) as the specific epithet of the species name. Breed, Lessel and Clise (1957, 395-397) also used multocida but indicated the possible priority of 
gallicida (from the "completely forgotten" Micrococcus gallicidus Burrill 1883, 320) and mentioned the wide usage of choleraegallinarum (from Micrococcus cholerae gallinarum Zopf 1885, 57). Breed et al. employed multocida because of its early use and because of its appropriateness; they stated that septica (from Pasteurella septica Topley and Wilson 1929, 488) is currently employed in England as the specific epithet, likewise because of its appropriateness. Breed et al. conclude that under a strict application of the rules gallicida would be the correct specific epithet; they further conclude that action should be taken by the Judicial Commission to clarify the confusion that exists in regard to the correct specific epithet.

Relationship to actinomycetes:

Pasteurella lignieresi (Brumpt) Vuillemin 1931, 136.

Actinobacillus lignieresi Brumpt 1910, 849.

Nocardia lignieresi (Brumpt) Chalmers and Christopherson 1916 , 242 .

Discomyces lignieresi (Brumpt) Brumpt 1922, 993.

Pfeifferella Labbé 1899, 60. (A genus of protozoa.) not Pfeifferella Buchanan 1918a, 54. (Nomen rejiciendum)

Validly published

Type species (according to Becker 1951, 108): Pfeifferella tritonis

(Labbé) Labbé 1899, 60. (Basionym: Pfeifferia tritonis Labbé 1896, 540.)

Relationship to actinomycetes: An earlier homonym of Pfeifferella

Buchanan, $\mathrm{q} \cdot \underline{\mathrm{v}}$.

Pfeifferella Buchanan 1918a, 54. (Nomen rejiciendum)

not Pfeifferella Labbé 1899,60 . (A genus of protozoa.)

Malleomyces Pribram 1933, 11.

not Malleomyces Hallier $1870,119$.

Loefflerella Gay et al. 1935, 783.

Validly published.

Illegitimate.

Type species (original designation): Pfeifferella mallei (Zopf)

Buchanan 1918a, 54. (Basionym: Bacillus mallei Zopf 1885, 89.)

Comments: A later homonym of Pfeifferella Labbé (Rule 24d). Placed in the list of rejected names by the Judicial Commission (Opinion 14, 1954d, 156-158).

Relationship to actinomycetes: Placed by Pribram $(1929,375)$ in the tribe Actinobacilleae, family Mycobacteriaceae, order Actinomycetales and by Baldacci $(1939,9 \overline{4) \text { in the subfamily Leptotrichioideae }}$ Baldacci, family Mycobacteriaceae, order Actinomycetales.

Pfeifferella mallei (Zopf) Buchanan, 1918a, 54.

Corynebacterium mallei (Zopf) Lehmann and Neumann 1899, 366. Mycobacterium mallei (Zopf) Migula (according to Chester 1901, 353).

Cladascus mallei (Zopf) Enderlein 1917a, 395.

Actinobacillus mallei (Zopf) Thompson 1933, 226. 
Phleobacterium Pribram 1929, 375.

Not validly published.

Type species: None designated.

Comments: Not validly published because no species were named or described as belonging to the genus (Rule 13).

The etymology of Phleobacterium and its placement by Pribram with Mycobacterium in the tribe Mycobactereae suggest that Pribram based this generic name on Mycobacterium phlei, the "timothy bacillus," but no statement has been found to this effect.

In a later work, Pribram (1933) does not list Phleobacterium either in the order Mycobacteriales or in any other place.

Relationship to actinomycetes: Placed by Pribram $(1929,375)$ in the tribe Mycobactereae ( $\underline{\text { sic }}$ ), family Mycobacteriaceae, order Actinomycetales.

Phytomyxa Schroeter 1886, 134.

Rhizobium Frank 1889, 338.

Rhizobacterium Kirchner 1896, 221

Rhizomonas Orla-Jensen 1909, 328. (Nomen rejiciendum)

not Rhizomonas Kent 1880, 224. (A genus of protozoa.)

Validly published.

Legitimate.

Type species (subsequent designation: Buchanan 1925, 425): Phytomyxa leguminosarum (Frank) Schroeter 1886, 135. (Basionym: Schinzia leguminosarum Frank 1879, 397.)

Comments: See "Comments" under Rhizobium Frank for a discussion of the status of the name Phytomyxa Schroeter.

Relationship to actinomycetes: Synonym of Rhizomonas Orla-Jensen, $q \cdot \underline{v}$.

Pionnothrix Wollenweber 1921, 27. (Subgenus)

Nocardia Trevisan $1889 a, 9$.

Validly published.

Illegitimate.

Type species (Rule 24a): Nocardia (Pionnothrix) farcinica Trevisan $1889 a, 9$.

Comments: Wollenweber divided the genus Actinomyces Harz into two subgenera, Methrix and Pionnothrix. In the latter subgenus were included five species, among them Actinomyces farcinicus (Trevisan) Gasperini (Nocardia farcinica Trevisan). Inasmuch as Nocardia farcinica is the type species of the genus Nocardia, it follows that a later subgenus containing this species should be named Nocardia (Rules $5 \mathrm{~b}$ and 24a); therefore the subgeneric name Pionnothrix Wollenweber is to be regarded as a later synonym of the generic name Nocardia Trevisan (Rule 24a).

Relationship to actinomycetes: See "Comments" above.

Pleuropneumonia Tulasne and Brisou 1955, 237.

Asterococcus Borrel, Dujardin-Beaumetz, Jeantet and Jouan 1910, 179. 
not Asterococcus Scherffel 1908, 762. (A genus of algae.) Mycoplasma Nowak 1929, 1349. (Nomen conservandum)

Asteromyces Wroblewski 1931, 105.

Borrelomyces Turner 1935, 26.

Bovimyces Sabin 1941, 57.

Validly published.

Illegitimate.

Type species (original designation): Pleuropneumonia bovis Tulasne and Brisou 1955, 237.

Comments: A later synonym of Mycoplasma Nowak (Rule 24a).

Tulasne and Brisou $(1955,237)$ state: ". . nous proposons la création d'un ordre nouveau: cellui des pleuropneumoniales, qui rassemblera toutes les espèces décrites jusqu'ici et provisoirement classées dans la famille des Borrelomycetaceae (Turner, 1935), des Parasitaceae (Sabin, 1941) et le genre Asterococcus [1]. .... Dans cet ordre on admettra une seule famille: Pleuropneumoniaceae, un genre unique: Pleuropneumonia.. ... Espèce type: Pleuropneumonia bovis." It is evident that the generic name Pleuropneumonia was proposed as a substitute name for Asterococcus Borrel et al.

The specific epithet "bovis" of the type species of this genus is illegitimate (Rule 24b); the earliest legitimate specific epithet for this species is "mycoides" (from Asterococcus mycoides Borrel et al. 1910, 179).

Relationship to actinomycetes: A synonym of Asterococcus Borrel et al., $\underline{g} \cdot \underline{\mathrm{v}}$.

Plocamobacterium Löwi 1920, 733.

Validly published.

Legitimate.

Type species (monotypy): Plocamobacterium crassum (Lipschütz)

Löwi 1920, 733. (Basionym: Bacillus crassus Lipschütz 1913, 64.)

Relationship to actinomycetes:

Plocamobacterium bulgaricum (Luerssen and Kühn) Lehmann and Neumann 1927, $51 \overline{1}$.

Lactobacterium bulgaricum (Luerssen and Kuhn) Krassilnikov 1949, 212.

Plocamobacterium acidophilum (Moro) Lehmann and Neumann 1927, 510.

Bifidobacterium acidophilum (Moro) Prévot (according to Hauduroy et al. 1953, 104).

Pollendera Trevisan 1884b (according to Trevisan 1885b, 95).

T?) Bacteridium Davaine 1868, 26.

not Bacteridium Schroeter 1872 (according to Castellani and Chalmers 1919, 933). (Not validly published.)

Aplanobacter Smith 1905, 171.

Bacteridium (Davaine) Buchanan 1918a, 37. (Subgenus) 
Validly published.

Legitimacy indeterminate.

Type species (monotypy): Pollendera anthracis (Cohn) Trevisan 1884b.

(Basionym: Bacillus anthracis Cohn 1872, 177.)

Comments: The legitimacy of this generic name is dependent upon whether the type species of Bacteridium Davaine is $\underline{B}$. fermenti Davaine or B.anthracis (Cohn) Hauduroy et al. (see "Comments" under Bacteridium Davaine). Designation of the former as type would render Pollendera legitimate; designation of the latter would render Pollendera illegitimate as a later synonym of Bacteridium Davaine (Rule z4a).

Relationship to actinomycetes: A synonym of Aplanobacter Smith, $\underline{q} \cdot \underline{v}$.

Polysepta Bisset and Thompson (according to Welsch 1959, 18).

Status nat yet determined; reference to Bisset and Thompson unknown.

Relationship to actinomycetes: Welsch $(1959,19)$ stated that the organisms placed in this genus were described in the past by many authors as actinomycetes and that they possess the general characters of the actinomycetes.

Proactinomyces Jensen 1931, 355.

Group II, Jensen $1931,352$.

Validly published.

Legitimate.

Type species (subsequent designation: Hauduroy et al. 1953, 406): Proactinomyces agrestis (Gray and Thornton) Jensen 1931, 364.

(Basionym: Mycobacterium agreste Gray and Thornton 1928, 84.)

Comments: Although Jensen (1931, 352) stated that (his): "Group II

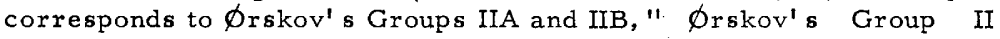
does not include the type species of the genus Proactinomyces Jensen (Jensen's Group II); therefore, strictly speaking, Jensen's Group II is not identical with $\phi_{\text {rskov's Group II. }}$

Relationship to actinomycetes: Placed by Jensen $(1931,355)$ in the Actinomycetales.

Propionibacterium Orla-Jensen 1909, 337.

Validly published.

Legitimate

Type species (subsequent designation: van Niel 1928, 160): Propionibacterium freudenreichii van Niel 1928, 161.

Comments: The only organisms placed in this genus by Orla-Jensen $(1909,337)$ were "die Propionsäurebakterien" of von Freudenreich and Orla-Jensen $(1907,534)$, who included in their group the following newly named and described species: 1) Bacterium acidi propionici a (p. 534), 2) Bacterium acidi proptonici b (p. 534) and Bacillus acidi propionici (p. 536). However, the first two names are not binary combinations, hence were not validly published (Rule 14a(1)). According to Rule 6, the single specific epithet in the name Bacillus acidi 
propionici is not to be rejected, but the two words which constitute this epithet are to be hyphenated or joined.

In conformity with Opinion 20(4) (Judicial Commission 1958b, 162), the combinations Propionibacterium acidi-propionici a, $P$. acidipropionici $b$ and $\underline{P} . \overline{\text { acidi-propionici }}$ are to be ascribed to Or $\overline{l a}-\overline{J e n s e n}$ $(1909,337)$.

Van Niel (1928, 160 and 161) recognized that acidi-propionici a did not constitute a single specific epithet and proposed the epithet freudenreichii to replace it. He then designated Propionibacterium freudenreichii (Bacterium acidi-propionici a von Freudenreich and OrlaJensen) as the type species of this genus.

Relationship to actinomycetes: Placed by Kluyver and van Niel (1936, 391) in the tribe Corynebacterieae, family Mycobacteriaceae, by Krassilnikov $(1949, \overline{151)}$ in the family Mycobacteriaceae, order Mycobacteriales, and by Prévot $(1948,26 ; 1953,137)$ as a subgenus of Bifidobacterium Orla-Jensen, family Actinomycetaceae, order Actinobacteriales, class Actinomycetales (sic).

Proteus Müller 1786, 9. (A genus of protozoa.)

not Proteus Hauser 1885, 12 .

Validly published.

Type species (according to Becker 1951, 109): Proteus diffluens Müller 1786, 9.

Relationship to actinomycetes: A homonym of Proteus Hauser, $q . v$.

Proteus Hauser 1885, 12.

not Proteus Muiller 1786, 9. (A genus of protozoa.)

Eisenbergia Enderlein $1917 \mathrm{~b}, 315$.

Validly published.

Legitimacy questionable.

Type species (subsequent designation: Buchanan 1918a, 54): Proteus vulgaris Hauser 1885, 12 .

Comments: Proteus Hauser 1885 appears to be illegitimate as a later homonym of the validly published protozoan generic name Proteus Müller 1786 (Rule 24d). The latter name is regarded as an illegitimate generic name in protozoology as a later homonym of Proteus Laurenti 1768 (Becker 1951, 109). Becker (loc. cit.) suggested that: "It may be desirable to request that Proteus Hauser be made a genus conservandum in bacteriology, inasmuch as Proteus is not currently used as a generic name in protozoology. "Such action would be in conformity with Principle 1(1): "...to aim at fixity of names. "

Relationship to actinomycetes: A synonym of Eisenbergia Enderlein, $\underline{q} \cdot \underline{v}$.

Pseudobacterium Trevisan 1888,781 .

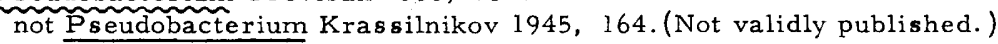
not Pseudobacterium Krassilnikov 1949, 220.

Not validly published. 
Type species: None designated.

Comments: Not validly published because it was merely incidentally mentioned by Trevisan (Rule $12 \mathrm{c}(3)$ ), as follows: "Senza dipartirci da Klebsiella, basterebbe ricordare come, tra le specie che attualmente se ne conoscono, altre $s^{\prime}$ ebbero le denominazioni generiche Micrococcus, Diplococcus, Pseudodiplococcus, ed altre quelle di Bacterium, Pseudobacterium, Proteus, Bacillus, Ascobacillus..." Relationship to actinomycetes: A homonym of Pseudobacterium Krassilnikov, q. $\mathbf{v}$.

Pseudobacterium Krassilnikov 1945, 167.

not Pseudobacterium Trevisan 1888, 781. (Not validly published.)

not Pseudobacterium Krassilnikov 1949, 220.

Not validly published.

Comments: No species were originally included in this genus, hence this generic name was not validly published (Rule 13b).

Relationship to actinomycetes: An earlier homonym of Pseudobacterium Krassilnikov 1949 (see Addendum).

Pseudoleptothrix Prévot 1938, 298.

Validly published.

Legitimate.

Type species: None designated.

Comments: Breed and Pederson $(1948,366)$ stated that Prévot (1938, 301) regarded Pseudoleptothrix innominata (Miller) Prévot as the type species of this genus; however, an examination of Prevot's paper reveals no such designation by Prévot.

Relationship to actinomycetes: Placed by Prévot $(1938,301)$ in the family Sphaerophoraceae, order Actinomycetales.

Pseudonocardia Henssen 1957, 408.

Validly published.

Legitimate.

Type species (monotypy): Pseudonocardia thermophila Henssen 1957, 408.

Relationship to actinomycetes: Placed by Henssen $(1957,385)$ in the family Streptomycetaceae.

Pseudorhizobium Hartleb 1900, 888.

Validly published.

Legitimate.

Type species (monotypy): Pseudorhizobium ramosum Hartleb 1900, 888 .

Relationship to actinomycetes: Allen and Allen (1939, 89) listed Pseudorhizobium ramosum as the name of a species which belongs to the genus Rhizobium Frank. Rhizobium Frank is a synonym of Rhizomonas Orla-Jensen, which was placed with the actinomycetes by Orla-Jensen $(1909,334)$. 
Pseudospira Trevisan 1889a, 23. (Subgenus) (Nomen rejiciendum)

Pacinia Trevisan $1885 \mathrm{a}, 83$.

Microspira Schroeter 1886, 168.

Validly published.

Illegitimate.

Type species (subsequent designation: Judicial Commission, Opinion 13, 1954c, 154): Pacinia (Pseudospira) cholerae-asiaticae Trevisan $1885 \mathrm{a}, 84$.

Comments: Trevisan (1889a, 23) divided the genus Pacinia Trevisan into two subgenera (later indicated by Trevisan ( $18 \overline{89 \mathrm{~b}, 10} 15$ and 1018 ) to be Sections), Eupacinia and Pseudospira. The latter subgenus contained seven species, among them Pacinia cholerae-asiaticae Trevisan. Inasmuch as Pacinia cholerae-asiaticae is the type species of the genus Pacinia, it follows that a later subgenus containing this species should be named Paciria (Rules $5 \mathrm{~b}$ and $24 \mathrm{a}$ ). Pseudospira Trevisan has been placed in the list of rejected generic names by the Judicial Commission (Opinion 13, 1954c, 154).

Relationship to actinomycetes: A synonym of Pacinia Trevisan, $\underline{q} \cdot \underline{v}$.

Pseudostreptus Enderlein $1917 \mathrm{~b}, 317$.

Streptococcus Rosenbach 1884, 22.

not Streptococcus Cohn 1875, 204.

Validly published.

Illegitimate.

Type species (original designation): Pseudostreptus pyogenes (Rosenbach) Enderlein 1917b, 317. (Basionym: Streptococcus pyogenes Rosenbach 1884, 22.)

Comments: Illegitimate as a later synonym of Streptococcus Rosenbach 1884 (Rule 24a).

Relationship to actinomycetes: Placed by Enderlein (1917b, 317) in the subfamily Pseudostreptinae Enderlein, family Corynobacteriidae Enderlein.

Rhizobacterium Kirchner 1896, 221.

Phytomyxa Schroeter 1886, 134.

Rhizobium Frank 1889, 338 .

Rhizomonas Orla-Jensen 1909, 328. (Nomen rejiciendum) not Rhizomonas Kent 1880, 224. (A genus of protozoa.)

Validly published.

Illegitimate.

Type species (according to Rule 9c(3)(d)): Rhizobacterium leguminosarum (Frank) Kirchner 1896, 221. (Basionym: Schinzia leguminosarum Frank 1879, 397.)

Comments: A later synonym of Phytomyxa Schroeter (Rule 24a).

Relationship to actinomycetes: $\overline{\text { A synonym }}$ of Rhizomonas Orla-Jensen, which was placed with the actinomycetes by Orla-Jensen $(1909,334)$. 
Rhizobium Frank 1889, 338.

Phytomyxa Schroeter 1886, 134.

Rhizobacterium Kirchner 1896, 221.

Rhizomonas Orla-Jensen 1909, 328. (Nomen rejiciendum)

not Rhizomonas Kent 1880, 224. (A genus of protozoa.)

Validly published.

Legitimacy questionable.

Type species (monotypy): Rhizobium leguminosarum (Frank) Frank 1889, 338. (Basionym: Schinzia leguminosarum Frank 1879, 397.)

Comments: The generic names Phytomyxa Schroeter 1886 and Rhizobium Frank 1889 are both based upon the same type species, the basionym of which is Schinzia leguminosarum Frank, and Rhizobium, being the later synonym, would appear to be illegitimate (Rule 24a). Schroeter $(1886,133-134)$ placed Phytomyxa in the family Phytomyxacei, order Phytomyxini, division Myxomycetes of the fungi. However the two organisms Schroeter originally placed in the genus Phytomyxa ( $\underline{P}$. leguminosarum (Frank) Schroeter and $\underline{P}$. lupini Schroeter) were later shown to be bacteria, and the generic name Phytomyxa, as well as the suprageneric names derived from it, has subsequently been rejected by mycologists (see von Tubeuf and Smith 1897, 101 and 524; Maire and Tison 1909, 227, 241, 244 and 248). Although the generic name Phytomyxa was validly published and is legitimate as the name of a genus of bacteria, its former association with the slime molds would provide a real source of confusion if it were now to be used as the name of a bacterial genus. In conformity with Principle 1(1): "...to aim at fixity of names," conservation of Rhizobium Frank may be necessary.

Relationship to actinomycetes: A synonym of Rhizomonas Orla-Jensen, which was placed with the actinomycetes by Orla-Jensen (1909, 334).

Rhizomonas Kent 1880, 224. (A genus of protozoa.) not Rhizomonas Orla-Jensen 1909, 328. (Nomen rejiciendum) Validly published.

Type species (monotypy): Rhizomonas verrucosa Kent 1880, 224.

Relationship to actinomycetes: An earlier homonym of Rhizomonas Orla-Jensen, q. $\underline{\text {. }}$

Rhizomonas Orla-Jensen 1909, 328. (Nomen rejiciendum)

not Rhizomonas Kent 1880, 224. (A genus of protozoa.)

Phytomyxa Schroeter 1886, 134.

Rhizobium Frank 1889, 338 .

Rhizobacterium Kirchner 1896, 221.

Validly published.

Illegitimate.

Type species (Rule 9c(3)(d)): The same as that of Rhizobium Frank, i.e. Rhizobium leguminosarum (Frank) Frank 1889, 338. (Basionym: Schinzia leguminosarum Frank 1879, 397.) 
Comments: Illegitimate as a later homonym of the protozoan generic name Rhizomonas Kent (Rule 24d) and as a later synonym of Phytomyxa Schroeter (Rule 24a). Placed in the list of rejected bacterial names by the Judicial Commission (Opinion 14, 1954d, 157).

Relationship to actinomycetes: Placed by Orla-Jensen $(1909,334)$ with the actinomycetes.

Ristella Prévot 1938, 290.

Bacteroides Castellani and Chalmers 1919, 959.

Validly published.

Illegitimate.

Type species (subsequent designation: Hauduroy et al. 1953, 471): Ristella fragilis (Veillon and Zuber) Prévot 1938, 290 . (Basionym: Bacillus fragilis Veillon and Zuber 1898, 536.)

Comments: Illegitimate as a later synonym of Bacteroides Castellani and Chalmers (Rule 24a).

Relationship to actinomycetes: Krassilnikov (1949, 243-248) transferred seventeen species of Ristella to the genus Pseudobacterium Krassilnikov of the family Mycobacteriaceae, order Mycobacteriales, class Actinomycetes.

Saccharobacillus van Laer 1892(?), 4.

Lactobacterium van Steenberge 1920, 806.

Lactobacterium Krassilnikov 1949, 208.

Validly published.

Legitimate.

Type species (monotypy): Saccharobacillus pastorianus van Laer 1892(?), 4.

Relationship to actinomycetes: A synonym of Lactobacterium Krassilnikov, $\underline{q} \cdot \underline{\text {. }}$.

Sarcina Goodsir 1842, 434.

Zymosarcina Smit 1930, 26.

Zymosarcina (Smit) Breed 1948, 285. (Subgenus)

Validly published.

Legitimate.

Type species (monotypy): Sarcina ventriculi Goodsir 1842, 433.

Comments: Kluyver and van Niel $(\overline{1936,400})$ designated Sarcina lutea Schroeter as the type species of this genus (Rule 9c(3)).

Relationship to actinomycetes: Placed by Krassilnikov (1949, 310 and 827 ) in the family Coccaceae, order Coccaceae (sic), class Actinomycetes.

Schinzia Năgeli 1842, 281. (A genus of fungi.) not Schinzia Dennstätt 1818 (according to Schroeter 1886, 134). Validly published.

Type species (according to Clements and Shear 1931, 339): Schinzia cellulicola Năgeli 1842, 283. 
Relationship to actinomycetes: Fred, Baldwin and McCoy (1932, 138) state that the nodule organism (i. e. Rhizobium leguminosarum (Frank) Frank) was initially placed by Frank in the species Schinzia cellulicola. Bergey et al. (1934, 44 and 45) list Schinzia cellulicola and Schinzia leguminosarum as names which have been used for species belonging to the genus Rhizobium Frank. Rhizobium Frank is a synonym of Rhizomonas Orla-Jensen, which was placed with the actinomycetes by Orla-Jensen (1909 334).

Sclerostroma Wollenweber 1921, 29. (Section)

Type species (Bot. Code, Art. 22): Actinomyces bovis Harz 1877, 485.

Comments: Wollenweber $(1921,29)$ divided the subgenus Aërothrix Wollenweber of the genus Actinomyces Harz into five sections, the first of which was Sclerostroma; this section included four species, one of which was Actinomyces bovis Harz, the type species of the genus Actinomyces Harz.

Neither provision nor specific prohibition is made in the Bacteriological Code (Principle 7) for recognition of an infrageneric rank termed "section." The Botanical Code (Art. 4) provides for "section" as a subdivision of a subgenus.

Article 22 of the Botanical Code states that: "The subgenus or section including the type species of the correct name of the genus to which it is assigned repeats that name unaltered as its epithet,..." Therefore, according to the Botanical Code, the section "epithet" Sclerostroma is illegitimate because it contained the type species (Actinomyces bovis Harz) of the genus. This section should have borne the name of the genus (Actinomyces) unaltered.

Relationship to actinomycetes: See "Comments" above.

Sclerothrix Kützing 1843, 229. (A genus of algae.)

not Sclerothrix Kützing 1849, 319. (A genus of algae.)

not Sclerothrix Metschnikoff 1888, 70.

Not validly published.

Comments: Used by Kutzing $(1843,229)$ in the combination Sclerothrix callitrichae, a name listed as a synonym (of Hypheothrix callitrichae) and hence not validly published (Bot. Code, Art. 37).

Relationship to actinomycetes: An earlier homonym of Sclerothrix Metschnikoff, $\underline{g} \cdot \underline{v}$.

Sclerothrix Kützing 1849, 319. (A genus of algae.)

not Sclerothrix Kützing 1843, 229. (A genus of algae.)

not Sclerothrix Metschnikoff 1888, 70.

Validly published.

Legitimate.

Type species (monotypy): Sclerothrix callitrichae Kützing 1849, 319.

Comments: The earlier homonym, Sclerothrix Kützing 1843, was not validly published; the later homonym, Sclerothrix Kützing 1849 , is therefore legitimate. 
Relationship to actinomycetes: An earlier homonym of Sclerothrix Metschnikoff, $\mathrm{q} \cdot \underline{\mathrm{v}}$.

Sclerothrix Metschnikoff 1888, 70.

not Sclerothrix Kützing 1843, 229. (A genus of algae.) not Sclerothrix Kützing 1849, 319. (A genus of algae.)

Coccothrix Lutz 1886, 98.

Mycobacterium Lehmann and Neumann 1896, 363.

Mycomonas Orla-Jensen 1909, 329.

Validly published.

Illegitimate.

Type species (monotypy): Sclerothrix tuberculosis (Zopf) Vuillemin

1913, 527. (Basionym: Bacterium tuberculosis Zopf 1883, 67.)

Comments: A later homonym of Sclerothrix Kützing 1849 (Rule 24d).

The only species placed in this genus at the time of its proposal was Koch's tubercle bacillus, which Metschnikoff named Sclerothrix kochii. However, the earliest legitimate specific epithet for this species is "tuberculosis" (from Bacterium tuberculosis Zopf 1883, 67), and the specific epithet "kochii" is illegitimate (Rule 24b). Vuillemin (1913, 527) corrected Sclerothrix kochii to Sclerothrtx tuberculosis.

Relationship to actinomycetes: A synonym of Mycobacterium Lehmann and Neumann, $\underline{q} \cdot \underline{v}$.

Sphaerocillus Prévot 1938, 300.

Spherocillus (sic) Prévot $1938,300$.

Validly published.

Legitimate.

Type species (subsequent designation: Breed and Hoffmann 1957, 450): Sphaerocillus bullosius (Distaso) Prévot 1938, 300. (Basionym: Bacillus bullosus Distaso 1912, 443.)

Relationship to actinomycetes: Placed by Prévot (1938, 305; 1940a, $17 ; 1948,44 ; 1953,137)$ in the actinomycetes.

Sphaerophorus Persoon 1794, 23. (A genus of lichens.) not Sphaerophorus Prévot 1938, 297.

Validly published.

Legitimate.

Type species (according to Clements and Shear, 1931, 316): Sphaerophorus coralloides Persoon 1794, 23.

Relationship to actinomycetes: An earlier homonym of Sphaerophorus Prévot, $\underline{g} \cdot \underline{v}$.

Sphaerophorus Prévot 1938, 297.

not Sphaerophorus Persoon 1794, 23. (A genus of lichens.)

Spherophorus (sic) Prévot 1938, 297.

Necrobacterium Lahelle and Thjötta 1945, 321. 
Validly published.

Illegitimate.

Type species (subsequent designation: Breed and Hoffman 1957, 441): Sphaerophorus necrophorus (Flügge) Prévot 1938, 298. (Basionym: Bacillus necrophorus Flugge 1886, 273.)

Comments: Illegitimate as a later homonym of Sphaerophorus Persoon (Rule 24d); as such it must be rejected and be replaced by Necrobacterium Lahelle and Thjötta, the oldest legitimate name for this taxon (Rule 26).

The spelling "Spherophorus" is an incorrect transliteration of the Greek; Breed and Hoffman (1957, 441) corrected the spelling to "Sphaerophorus" (see Appendix B, (b)4, Bact. Code).

Prévot $(1948,24)$ listed as the type species of this genus: "ㅁ. necrophorus, S. funduliformis (et 19 autres)." Such designation of a type species does not conform with Rule 9c(1).

Relationship to actinomycetes: Placed by Prévot (1938, 305; 1940a, $17 ; 1948,44 ; 1953,137)$ in the actinomycetes.

Sphaerotilus Kützing 1833, 386.

Validily published.

Legitimate.

Type species (monotypy): Sphaerotilus natans Kützing 1833, 386. Relationship to actinomycetes: Engler $(1907,5)$ listed ". . Sph. (Actinomyces) bovis, Geschwülste im Körper von Tieren und Menschen erzeugend..." under the genus Sphaerotilus.

Spherocillus Prévot 1938, 300 (an orthographic variant of Sphaerocillus Prevot, $\underline{g} \cdot \underline{v}$.$) .$

Spherophorus Prévot 1938, 297 (an orthographic variant of Sphaerophorus Prévot, $g \cdot \underline{v}$.).

Streptobacillus Maggi 1886, 173.

not Streptobacillus Hlava 1889, 139." (Not validly published.)

not Streptobacillus Unna 1892, 485. (Not validly published.)

not Streptobacillus Preisz 1894, 231 (according to Kruse 1896b, 452 and Migula 1900, 374). (Not validly published.)

not Streptobacillus Unna 1895a, 61.

not Streptobacillus Ucke 1898, 1000.

not Streptobacillus Rist and Khoury 1902, 70 (according to Enlows $1920,89)$.

not Streptobacillus Levaditi et al. 1925, 1188 (according to Freundt $1957 \mathrm{a}, 45 \mathrm{l})$.

Not validly published.

Comments: Not proposed as a generic name, hence has no standing in nomenclature. Maggi $(1886,173)$ used this name to refer to a particular kind of cell aggregation characteristic of certain species; he stated: "1. - Bacillus aceti Zopf in p. ; aussi à l' état de streptobacillus." 
Relationship to actinomycetes: A homonym of Streptobacillus Levaditi et $\underline{\mathrm{al}}$. $\mathrm{g} \cdot \underline{\mathrm{v}}$.

Streptobacillus Hlava 1889, 139.

not Streptobacillus Maggi, 1886, 173. (Not validly published.)

not Streptobacillus Unna 1892, 485. (Not validly published.)

not Streptobacillus Preisz 1894, 231 (according to Kruse 1896b, 452 and Migula 1900, 374). (Not validly published.)

not Streptobacillus Unna 1895a, 61.

not Streptobacillus Ucke $1898,1000$.

not Streptobacillus Rist and Khoury 1902, 70 (according to Enlows $1920,89)$.

not Streptobacillus Levaditi et al. 1925, 1188 (according to Freundt $1957 \mathrm{a}, 451)$.

Not validly published.

Comments: There is no indication that Hlava proposed Streptobacillus as a generic name, hence it has no standing in nomenclature.

Relationship to actinomycetes: A homonym of Streptobacillus Levaditi et al. , g. v.

Streptobacillus Unna 1892, 485.

not Streptobacillus Maggi 1886, 173. (Not validly published.) not Streptobacillus Hlava 1889, 139. (Not validly published.) not Streptobacillus Preisz 1894, 231 (according to Kruse 1896b, 452 and Migula 1900, 374). (Not validly published.)

not Streptobacillus Unna 1895a, 61 .

not Streptobacillus Ucke 1898, 1000.

not Streptobacillus Rist and Khoury 1902, 70 (according to Enlows $1920,89)$.

not Streptobacillus Levaditi et al. 1925, 1188 (according to Freundt $1957 \mathrm{a}, 451)$.

Not validly published.

Comments: Not proposed as a generic name, hence has no standing in nomenclature. Unna $(1892,487)$ used this name to refer to the particular kind of cell aggregation characteristic of the organism he was describing.

Relationship to actinomycetes: A homonym of Streptobacillus Levaditi et al., g.

Streptobacillus Preisz 1894, 231 (according to Kruse 1896b, 452 and Migula 1900, 374).

not Streptobacillus Maggi 1886, 173. (Not validly published.)

not Streptobacillus Hlava 1889, 139. (Not validly published.)

not Streptobacillus Unna 1892, 485. (Not validly published.)

not Streptobacillus Unna 1895a, 61 .

not Streptobacillus Ucke 1898, 1000.

not Streptobacillus Rist and Khoury 1902, 70 (according to Enlows $1920,89)$. 
not Streptobacillus Levaditi et al. 1925, 1188 (according to Freundt $1957 \mathrm{a}, 451)$.

Not validly published.

Comments: Kruse (1896b, 452) stated that: "Preisz, dem wir eine grtindliche vergleichende Studie über diese Bacillen verdanken, will den Mikroorganismus als Streptobacillus pseudotuberculosis rodentium bezeichnen (P. 94. 4)" and Migula (1900, 374) cited "Streptobacillus pseudotuberculosis rodentium Preisz... Ann. de $\mathrm{l}^{\prime}$ Inst. Pasteur, T. VIII, 1894, p. 231" in synonymy. However, an examination of Preisz' paper reveals no such name, and inasmuch as neither Kruse nor Migula intended to introduce the name Streptobacillus, it was not validly published (Rule $12 \mathrm{c}(3)$ ).

A pertinent statement by Preisz $(1894,247)$ is: ". . nous proposons de dénommer cette maladie "la pseudotuberculose des rongeurs (pseudotuberculosis rodentium), et d'appeler avec $M$. Dor streptobacille son agent producteur, car ce terme rappelle un des caractères importants de ce bacille..."

Enlows (1920, 89) incorrectly stated that "Flügge [Kruse]" attributed this generic name to "Pfeiffer, 1889."

Relationship to actinomycetes: A homonym of Streptobacillus Levaditi et $\underline{\mathrm{al}}$. , $\mathrm{g} \cdot \underline{\mathrm{v}}$.

Streptobacillus Unna 1895a, 61 .

not Streptobacillus Maggi 1886, 173. (Not validly published.)

not Streptobacillus Hlava 1889,139 . (Not validly published.)

not Streptobacillus Unna 1892, 485. (Not validly published.)

not Streptobacillus Preisz 1894, 231 (according to Kruse 1896b, 452 and Migula 1900, 374). (Not validly published.)

not Streptobacillus Ucke 1898, 1000.

not Streptobacillus Rist and Khoury 1902, 70 (according to Enlows

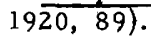

not Streptobacillus Levaditi et al. 1925, 1188 (according to Freundt $1957 a, 451$ ).

Validly published.

Legitimate.

Type species (monotypy): Streptobacillus ulceris-mollis Unna 1895a, 61 ; also see Unna 1895b, 275. (Streptobacillus ulceris mollis (sic) Unna 1895a, 61.).

Relationship to actinomycetes: A homonym of Streptobacillus Levaditi et $\underline{\text { al. }}, \underline{g} . \underline{\mathrm{v}}$.

Streptobacillus Ucke 1898, 1000.

not Streptobacillus Maggi 1886, 173. (Not validly published.)

not Streptobacillus Hlava 1889,139 . (Not validly published.)

not Streptobacillus Unna 1892, 485. (Not validly published.)

not Streptobacillus Preisz 1894, 231 (according to Kruse 1896b, 452 and Migula 1900, 374). (Not validly published.) 
not Streptobacillus Unna 1895a, 61.

not Streptobacillus Rist and Khoury 1902, 70 (according to Enlows $1920,89)$.

not Streptobacillus Levaditi et al. 1925, 1188 (according to Freundt $1957 \mathrm{a}, 451)$.

Validly published.

Illegitimate.

Type species (monotypy): Streptobacillus terrae Ucke 1898, 1001.

Comments: Ucke did not indicate that he proposed Streptobacillus as a new generic name. His single species, $S$. terrae, is quite different from S. ulceris-mollis, the type species of Streptobacillus Unna $1895 \mathrm{a}$. If regarded as a new generic name, Streptobacillus Ucke would be illegitimate as a later homonym of Streptobacillus Unna (Rule 24d).

Relationship to actinomycetes: A homonym of Streptobacillus Levaditi et $\underline{\text { al. }}$, q.

Streptobacillus Rist and Khoury 1902, 70 (according to Enlows 1920, 89). not Streptobacillus Maggi 1886, 173. (Not validly published.) not Streptobacillus Hlava 1889, 139. (Not validly published.) not Streptobacillus Unna 1892, 485. (Not validly published.) not Streptobacillus Preisz 1894, 231 (according to Kruse 1896b, 452 and Migula 1900, 374). (Not validly published.)

not Streptobacillus Unna 1895a, 61 . not Streptobacillus Ucke 1898, 1000. not Streptobacillus Levaditi et al. 1925, 1188 (according to Freundt $1957 \mathrm{a}, 451)$.

Validly published.

Illegitimate.

Type species (monotypy): Streptobacillus lebenis Rist and Khoury $1902,70$.

Comments: Rist and Khoury did not indicate that they proposed Streptobacillus as a new generic name, although it is listed as such by Enlows $(1920,89)$. The single species included in this genus by Rist and Khoury, S. lebenis, is quite different from $\underline{S}$. ulceris-mollis, the type species of Streptobacillus Unna 1895a. If regarded as a new generic name, Streptobacillus $R$ ist and Khoury would be illegitimate as a later homonym of Streptobacillus Unna (Rule 24d).

Relationship to actinomycetes: A homonym of Streptobacillus Levaditi et al., $\mathrm{g} \cdot \mathrm{v}$.

Streptobacillus Levaditi et al. 1925, 1188 (according to Freundt 1957a, 451).

not Streptobacillus Maggi 1886, 173. (Not validly published.) not Streptobacillus Hlava 1889, 139. (Not validly published.) not Streptobacillus Unna 1892, 485. (Not validly published.) 
not Streptobacillus Preisz 1894, 23 l (according to Kruse 1896b, 452 and Migula 1900, 374): (Not validly published.)

not Streptobacillus Unna 1895a, 61.

not Streptobacillus Ucke 1898, 1000.

not Streptobacillus Rist and Khoury 1902, 70 (according to Enlows

$1920,89)$.

Validly published.

Illegitimate.

Type species (monotypy): Streptobacillus moniliformis Levaditi et al. $1925,1188$.

Comments: Levaditi et al. did not indicate that they proposed Streptobacillus as a new generic name, although it is recognized as such by Freundt (1957a, 451). The single species included in this genus by Levaditi et al., $\underline{\mathbf{S}}$. moniliformis, is quite different from $\underline{\mathrm{S}}$. ulceris mollis, the type species of Streptobacillus Unna 1895a. If regarded as a new generic name, Streptobacillus Levaditi et al. would be illegitimate as a later homonym of Streptobacillus Unna (Rule 24d).

Relationship to actinomycetes: The following synonyms, among others, were listed by Freundt (1957a, 451):

Streptobacillus moniliformis Levaditi et al. 1925, 1188.

Streptothrix muris ratti Schottmülle r $1914,87$.

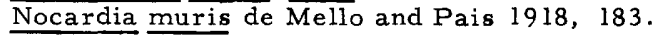

Actinomyces muris ratti Lieske $1921,31$.

Haverhillia multiformis Parker and Hudson 1926, 358.

Actinomyces muris Topley and Wilson 1936, 274.

Proactinomyces muris Krassilnikov 1941, 76.

Streptobacterium Maggi 1886, 84.

not Streptobacterium Billet 1890, 23.

not Streptobacterium Jacqué and Masay 1912, 181.

not Streptobacterium Orla-Jensen 1919, 166.

not Streptobacterium (Orla-Jensen) Pederson 1948, 350. (Subgenus)

Not validly published.

Comments: Not proposed as a generic name, hence has no standing in nomenclature. Maggi $(1886,85)$ used this name to refer to a particular kind of cell aggregation characteristic of certain species; he stated: "2. -Bacterium sp. ? ... étroitement réunis deux à deux (Diplobacterium), rarement quatre à quatre (Tetrabacterium ou Streptobacterium)."

Relationship to actinomycetes: An earlier homonym of Streptobacterium Orla-Jensen, q.v.

Streptobacterium Billet 1890, 23.

not Streptobacterium Maggi 1886, 84.

not Streptobacterium Jacqué and Masay 1912, 181.

not Streptobacterium Orla-Jensen 1919, 166.

not Streptobacterium (Orla-Jensen) Pederson 1948, 350. (Subgenus) 
Not validly published.

Type species: None designated.

Comments: Not validly published because no species were named or described as belonging to the genus (Rule 13).

Relationship to actinomycetes: An earlier homonym of Streptobacterium Orla-Jensen, $\underline{g} \cdot \underline{v}$.

Streptobacterium Jacqué and Masay 1912, 181.

not Streptobacterium Maggi 1886, 84.

not Streptobacterium Billet 1890, 23.

not Streptobacterium Orla-Jensen 1919, 166.

not Streptobacterium (Orla-Jensen) Pederson 1948, 350. (Subgenus)

Validly published.

Legitimate.

Type species (monotypy): Streptobacterium foetidum Jacqué and Masay $1912,181$.

Comments: The earlier homonyms Streptobacterium Maggi 1886 and Streptobacterium Billet 1890 were not validly published; the later homonym Streptobacterium Jacqué and Masay is therefore legitimate.

Relationship to actinomycetes: An earlier homonym of Streptobacterium Orla-Jensen, $g \cdot \underline{v}$.

Streptobacterium Orla-Jensen 1919, 166.

not Streptobacterium Maggi 1886, 84 .

not Streptobacterium Billet 1890, 23.

not Streptobacterium Jacqué and Masay 1912, 181.

Streptobacterium (Orla-Jensen) Pederson 1948, 350. (Subgenus)

Validly published.

Illegitimate.

Type species (subsequent designation: Kluyver and van Niel 1936, 401): Streptobacterium casei Orla-Jensen 1919, 166.

Comments: Illegitimate as a later homonym of Streptobacterium Jacqué and Masay 1912 (Rule 24d); the earlier homonyms Streptobacterium Maggi 1886 and Streptobacterium Billet 1890 were not validly published.

Relationship to actinomycetes: Placed by Kluyver and van Niel (1936, 391 ) in the tribe Corynebacterieae, family Mycobacteriaceae.

Streptobacterium (Orla-Jensen) Pederson 1948, 350. (Subgenus) not Streptobacterium Maggi 1886, 84.

not Streptobacterium Billet 1890, 23.

not Streptobacterium Jacqué and Masay 1912, 181.

Streptobacterium Orla-Jens en 1919, 166.

Validly published.

Illegitimate.

Type species (Rule 5c): Lactobacillus casei (Orla-Jensen) Holland 1920, 221. (Basionym: Streptobacterium casei Orla-Jensen 1919, 166.) 
Comments: A later homonym of Streptobacterium Jacqué and Masay 1912 (Rule 24d); the earlier homonyms Streptobacterium Maggi 1886 and Streptobacterium Billet 1890 were not validly published.

Relationship to actinomycetes: A subgenus of Lactobacillus Beijerinck, $\underline{q .}$. ; also see Streptobacterium Orla-Jensen.

Streptococcus Cohn 1875, 204.

not Streptococcus Rosenbach 1884, 22.

Not validly published.

Type species: None designated.

Comments: Cohn $(1875,204)$ used the name Streptococcus (from Billroth) in a generic sense, but he did not name or describe any species as belonging to the genus, hence Streptococcus Cohn was not validly published (Rule 13).

Relationship to actinomycetes: A homonym of Streptococcus Rosenbach, g. v.

Streptococcus Rosenbach 1884, 22.

not Streptococcus Cohn 1875, 204.

Pseudostreptus Enderlein 1917b, 317.

Validly published.

Legitimate.

Type species (subsequent designation: Winslow et al. 1917, 558):

Streptococcus pyogenes Rosenbach 1884, 22.

Comments: The earlier homonym, Streptococcus Cohn, was not, validly published, hence Streptococcus Rosenbach is legitimate.

The terms "streptococcos" and "streptococcus" had been used by various authors prior to Rosenbach (e.g. Billroth 1874, 10; Cohn 1875, 144; Ogston 1883, 27; Zopf 1883, 10 and 1884, 10) to designate a particular kind of cell aggregation. These names were not used in a generic sense and therefore have no standing in nomenclature.

Kluyver and van Niel (1936, 401) incorrectly cited "Streptococcus lactis (Lister) Löhnis" as the type. species of this genus (Rule 9c(3)).

Relationship to actinomycetes: Placed by Krassilnikov (1949, 827) in the family Coccaceae, order Coccaceae (sic), class Actinomycetes.

Streptomyces Waksman and Henrici 1943, 339.

Validly published.

Legitimate.

Type species (original designation): Streptomyces albus (Rossi Doria) Waksman and Henrici 1943, 339. (Basionym: Streptothrix alba Rossi Doria 1891, 421.)

Relationship to actinomycetes: Placed by Waksman and Henrici (1943, 339) in the actinomycetes.

Streptosporangium Couch 1955, 149.

Validily published.

Legitimate. 
Type species (original designation): Streptosporangium roseum Couch $1955,151$.

Relationship to actinomycetes: Placed by Couch $(1955,148)$ in the order Actinomycetales.

Streptothrix Corda 1839, 27. (A genus of fungi.)

not Streptothrix Cohn 1875, 186.

Validly published.

Type species (monotypy): Streptothrix fusca Corda 1839, 27.

Relationship to actinomycetes: An earlier homonym of Streptothrix

Cohn, $\mathrm{g} \cdot \underline{\mathrm{v}}$.

Streptothrix Cohn 1875, 186.

not Streptothrix Corda 1839, 27. (A genus of fungi.)

Discomyces Pinoy and Morax 1911, 98.

not Discomyces Rivolta 1878, 208.

Cohnistreptothrix Pinoy 1911, 253. (Not validly published.)

Cohnistreptothrix Pinoy 1913, 931.

Validly published.

Illegitimate.

Type species (monotypy): Streptothrix foersteri Cohn 1875, 186.

Comments: A later homonym of Streptothrix Corda (Rule 24d). Of the later synonyms, Discomyces Pinoy and Morax is illegitimate and Cohnistreptothrix Pinoy 1911 was not validly published; hence these names are unavailable. The correct name of the genus which has Streptothrix foersteri Cohn as its type species is Cohnistreptothrix Pinoy 1913 .

Cohn (1875) named and described the species Streptothrix foersteri on p. 186 and then indicated Streptothrix to be a new genus on p. 204, where he gave a Latin diagnosis of both the genus and the single species as follows:

Streptothrix n.g. filamenta leptotrichoidea tenerrima achroa non articulata stricta vel anguste spiralia, parce ramosa.

Str. Foesteri [sic] sp. unic. filamenta in Micrococco mucoso nidulentia, concretiones in canaliculo lacrimali hominis raro repertas componentia.

Relationship to actinomycetes:

Streptothrix foersteri Cohn 1875, 186.

Nocardia foersteri (Cohn) Trevisan 1889a, 9.

Actinomyces foersteri (Cohn) Gasperini 1894a, 86.

Streptoverticillium Baldacci 1959, 278.

Validly published.

Legitimate.

Type species: None designated.

Comments: Baldacci $(1959,284)$ divided this genus into the following 
six Series: Circulatus, Griseocarneus, Cinnamomeus, Reticuli, Verticillatus and Rubrireticuli.

Relationship to actinomycetes: Placed by Baldacci $(1959,284)$ with the actinomycetes.

Thermoactinomyces Tsiklinsky 1898, 286.

not Thermoactinomyces Tsiklinsky 1899, 501 .

Not validly published.

Comments: Not validly published because it was not proposed as a generic name (Rule $12 \mathrm{c}(3)$ ). Tsiklinsky (1898, 286) stated: "Dans mes recherches sur les bactéries thermophiles $j^{\dagger} a i$ rencontré et isolé en cultures pures deux espèces d'Actinomyces végétant entre $48^{\circ}$ et $68^{\circ}$ centigrades. Le Thermoactinomyces I, isolé de la terre, ... Quand à l'autre espèce thermophile d'Actinomyces que $j^{\prime} a i$ isolée d'engrais..." Tsiklinsky apparently used "Thermoactinomyces" as a vernacular name, not a generic name.

Relationship to actinomycetes: An earlier homonym of Thermoactinomyces Tsiklinsky 1899, $\mathrm{g} \cdot \underline{\mathrm{v}}$.

Thermoactinomyces Tsiklinsky 1899, 501.

not Thermoactinomyces Tsiklinsky 1898, 286.

Validly published.

Legitimate.

Type species (monotypy): Thermoactinomyces vulgaris Tsiklinsky $1899,501$.

Comments: The earlier homonym, Thermoactinomyces Tsiklinsky 1898, was not validly published, hence Thermoactinomyces T siklinsky is legitimate.

Although two species were included by Tsiklinsky in this genus, only one of them, Thermoactinomyces vulgaris, was named; this then becomes the nomenclatural type (type species) by monotypy (see Enlows 1920, 92).

Relationship to actinomycetes: The two species originally included in this genus were regarded by $T$ siklinsky as actinomycetes. Tsiklinsky (1899, 501) stated: "Dans mes recherches sur les bactéries thermophiles, j'ai rencontré deux espè̃ces d'actinomyces végétant entre $48^{\circ}$ et $68: . "$

Thermobacterium Orla-Jensen 1919, 160.

Thermobacterium (Orla-Jensen) Pederson 1948, 350. (Subgenus)

Validly published.

Legitimate.

Type species (subsequent designation: Buchanan 1925, 501): Thermobacterium bulgaricum (Luerssen and Kühn) Orla-Jensen 1919, 164 .

(Basionym: Bacillus bulgaricus Luerssen and Kühn 1908, 241.)

Comments: Orla-Jensen (1919) did not indicate whether Thermobacterium bulgaricum, the type species of this genus, was a new species 
or a previously described species. Pederson $(1939,368)$, however, regarded it as identical with the earlier described Bacillus bulgaricus Luerssen and Kühn (Lactobacillus bulgaricus (Luerssen and Kühn) Holland).

Relationship to actinomycetes: Placed by Kluyver and van Niel (1936, 391) in the tribe Mycobacterieae, family Mycobacteriaceae.

Thermobacterium (Orla-Jensen) Pederson 1948, 350. (Subgenus) Thermobacterium Orla-Jensen 1919, 160.

Validly published.

Illegitimate.

Type species (Rule 5c): Lactobacillus bulgaricus (Luerssen and Kühn) Holland 1920, 217. (Basionym: Bacillus bulgaricus Luerssen and Kühn 1908, 241.)

Comments: Pederson (1948, 350) made Thermobacterium Orla-Jensen a subgenus of Lactobacillus Beijerinck, including in this subgenus both Lactobacillus bulgaricus and Lactobacillus caucasicus (Beijerinck) Beijerinck, the type species of the genus Lactobacillus Beijerinck. Therefore, Thermobacterium (Orla-Jensen) Pederson is illegitimate as the name of this subgenus, which contained the type species of the genus (Lactobacillus Beijerinck) and which should have borne the name of the genus unaltered(Rule 20). Pederson (1957, 541) corrected the name of this subgenus to Lactobacillus (Beijerinck) Pederson, of which Thermobacterium (Orla-Jensen) Pederson becomes a subjective synonym.

Relationship to actinomycetes: A subgenus of Lactobacillus Beijerinck, g. . . ; also see Thermobacterium Orla-Jensen.

Thermomonospora Henssen 1957, 398.

Validly published.

Legitimate.

Type species: None designated.

Relationship to actinomycetes: Placed by Henssen $(1957,385)$ in the family Streptomycetaceae.

Thermopolyspora Henssen 1957, 394.

Validly published.

Legitimate.

Type species: None designated.

Relationship to actinomycetes: Placed by Henssen $(1957,385)$ in the family Streptomycetaceae.

Thricomyces Petruski (according to Bellisari 1904, 467).

Not validly published.

Comments: Mentioned incidentally by Bellisari, hence not validly published (Rule 12c(3)). Bellisari did not indicate the source of this name, and although a paper has been found wherein Petruschky (1903, 
834) proposed the family name "Trichomyceten" to include Actinomyces, Streptothrix, Cladothrix and Leptothrix, no reference can be found for the proposal of the generic name Thricomyces by Petruschky.

The correct spelling of this name is Trichomyces (Rule 27, Recommendation 27a).

Relationship to actinomycetes: Regarded by Bellisari (1904, 467) as a synonym of Streptothrix, Actinomyces and Nocardia, among others.

\section{Tissieria Pribram 1929, 376.}

Bifidobacterium Orla-Jensen 1924, 472.

Bifidibacterium Prévot 1938, 301 (a later orthographic variant (Rule 27, Notes 2 and $6 \mathrm{c}$ ) of Bifidobacterium Orla-Jensen).

Validly published.

Illegitimate.

Type species (original designation): Tissieria bifida (Tissier) Pribram 1929, 376. (Basionym: Bacillus bifidus Tissier 1900, 85.)

Comments: Illegitimate as a later synonym of Bifidobacterium OrlaJensen (Rule 24a).

Although Pribram at first $(1929,376)$ did not make it evident whether the type species of Tissieria was a new species or a previously described species, he later $(1933,98)$ indicated that the type species was a previously described organism, "Bacterium bifidum Tissier."

Relationship to actinomycetes: Placed by Pribram (1929, 375 and 376) in the order Actinomycetales; also see Bifidobacterium Orla-Jensen.

Waksmania Lechevalier and Lechevalier 1957 (Aug. 23), 107.

Validly published.

Legitimate (but see Introduction, p. 91).

Type species (original designation): Waksmania rosea Lechevalier and Lechevalier 1957, 107.

Relationship to actinomycetes: Placed by Lechevalier and Lechevalier $(1957,104)$ in the family Streptomycetaceae, order Actinomycetales.

Zettnowia Enderlein 1917b, 315.

Validly published.

Legitimate.

Type species (original designation): Zettnowia racemosa (Zettnow) Enderlein 1917b, 315. (Basionym: Bacterium racemosum Zettnow 1915, 212.)

Relationship to actinomycetes: Placed by Enderlein (1917b, 315) in the subfamily Sclerotrichinae Enderlein, family Corynobacteriidae Enderlein, the latter name presumably being equivalent to Corynebacteriaceae Lehmann and Neumann.

Zygoplagia Enderlein 1917a, 396.

Validly published.

Legitimate. 
Type species (original designation): Zygoplagia alternans Enderlein $1917 a, 396$.

Relationship to actinomycetes: Placed by Enderlein (1917b, 317) in the subfamily Corynobacteriinae Enderlein, family Corynobacteriidae Enderlein, the latter name presumably being equivalent to Corynebacteriaceae Lehmann and Neumann.

Zymosarcina Smit 1930, 26.

Sarcina Goodsir 1842, 434.

Zymosarcina (Smit) Breed 1948, 285. (Subgenus)

Validly published.

Illegitimate.

Type species (subsequent designation: Kluyver and van Niel 1936, 400): Zymosarcina ventriculi (Goodsir) Smit 1930, 26. (Basionym: Sarcina ventriculi Goodsir 1842, 433.)

Comments: Illegitimate as a later synonym of Sarcina Goodsir (Rule 24a).

Relationship to actinomycetes: A synonym of Sarcina Goodsir, $\underline{g} \cdot \underline{v}$.

Zymosarcina (Smit) Breed 1948, 285. (Subgenus)

Sarcina Goodsir 1842, 434.

Zymosarcina Smit 1930, 26.

Validly published.

Illegitimate.

Type species (Rule 5c): Sarcina ventriculi Goodsir 1842, 433.

Comments: Breed (1948, 285) divided the genus Sarcina Goodsir into four subgenera: Zymosarcina, Methanosarcina, Sarcinococcus and Sporosarcina. The first subgenus included Sarcina ventriculi Goodsir, the nomenclatural type of the genus. When a genus is divided into subgenera, that subgenus which includes the type of the genus must bear the same name as the genus (Rule $5 \mathrm{c}$ ). The subgeneric name Zymosarcina (Smit) Breed is therefore a later synonym of the generic name Sarcina Goodsir, hence illegitimate (Rule 24a).

Relationship to actinomycetes: See Zymosarcina Smit. 


\section{ADDENDUM}

The fact that the following generic names, together with analyses of their nomenclature, should have been included in this study was not realized until after final proof had been prepared. Haverhillia Parker and Hudson and Pseudobacterium Krassilnikov 1949 are included here because they were omitted from the preceding section through a clerical error.

Conidiomyces Perroncito 1875, 599.

Relationship to actinomycetes: Mentioned by Waksman (1959b, 49) as having been placed in the actinomycetes either in whole or in part.

Haverhillia Parker and Hudson 1926, 358.

Validly published.

Legitimate.

Type species (original designation: p. 376): Haverhillia multiformis Parker and Hudson 1926, 358.

Comments: Prévot $(1948,25)$ regarded Haverhillia multiformis Parker and Hudson (1926) as a synonym of Streptobacillus moniliformi 8 Levaditi et al. (1925) and renamed the type species Haverhillia moniliformis (Levaditi et al.) Prévot. (Streptobacillus Levaditi et illegitimate as a later homonym of Streptobacillus Unna 1895a.)

Relationship to actinomycetes: Placed by Parker and Hudson (1926, 358 ) in the family Mycobacteriaceae of the order Actinomycetales and by Prévot (1948, 25) as a subgenus of the genus Sphaerophorus of the family Sphaerophoraceae of the class Actinomycetales (sic).

Hongo (according to Dodge 1935, 735).

Comments: Dodge $(1935,735)$ listed "Hongo artrosporado Ribeyro. Ann. Fac. Méd. Lima 3:1 5, 1 pl., $\overline{1919^{\prime \prime}}$ in synonymy. Hongo artrosporado may have been given as a species name; more probably it is merely spanish for "arthrosporous fungus."

Relationship to actinomycetes: Hongo artrosporado Ribeyro was listed by Dodge $(1935,735)$ as a synonym of Actinomyces ribeyro Dodge 1935, 735 and by Baldacci $(1947,77)$ as a doubtful synonym of "Actinomyces albus (Rossi-Doria) Gasperini, 1894."

Lepocolla (according to Brumpt 1910, 773). (Presumably a genus of fungi.)

Comments: The source of this generic name has not been located.

Relationship to actinomycetes:

Lepocolla repens Eklund 1883 (according to Brumpt 1910, 773). Nocardia repens (Eklund) Vuillemin 1931, 124. Actinomyces repens (Eklund) Nannizzi 1934, 42.

Madurella Brumpt 1905, 997. (A genus of fungi.)

Relationship to actinomycetes:

Madurella mycetomi (Laveran) Brumpt 1905, 997. 
Streptothrix mycetomi Laveran 1902 (according to Vuillemin 1931, 155).

Malbranchea Saccardo 1882, 639. (A genus of fungi.)

Relationship to actinomycetes: Regarded by Dodge $(1935,706)$ as a synonym of Actinomyces Harz.

Microsporoides (according to Dodge 1935, 741). (Presumàbly a genus of fungi.)

Comments: The source of this generic name has not been located.

Relationship to actinomycetes:

Microsporoides minutissimus (Burchardt) Neveu-Lemaire 1906

(according to Dodge 1935, 741).

Discomyces minutissimus (Burchardt) Brumpt 1910, 863.

Nocardia minutissima (Burchardt) Verdun 1912 (according to Dodge $1935,741)$.

Actinomyces minutissimus (Burchardt) Brumpt 1927, 1199.

Proactinomyces minutissimus (Burchardt) Krassilnikov 1941, 80 .

Microsporon Klebs 1871, 33. (Presumably a genus of fungi.)

not Microsporum Gruby 1843, 301 .

Relationship to actinomycetes: Murray and Breed $(1948,383)$ regarded Microsporon diphthericum Klebs 1883, 143 as the prototype of

Corynebacterium diphtheriae (Flugge) Lehmann and Neumann 1896, 350 .

Microsporum Gruby 1843, 301. (A genus of fungi.)

not Microsporon Klebs 1871,33 .

Relationship to actinomycetes:

Microsporum minimum (Le Calve and Malherbe) Castellani and Chalmers 19 $19,993$.

Actinomyces minimus (Le Calve and Malherbe) Dodge 1935, 728.

Pseudobacterium Krassilnikov 1949, 220.

not Pseudobacterium Trevisan 1888, 781. (Not validly published.)

not Pseudobacterium Krassilnikov 1945, 167. (Not validly published.)

Validly published.

Illegitimate.

Type species: None designated.

Comments: Illegitimate because the taxon to which it wàs applied included the nomenclatural types of the following earlier-proposed generic names: Bacteroides Castellani and Chalmers 1919, Microbacterium Orla- $\overline{\text { Jensen 1919, Protaminobacter den Dooren de Jong }}$ 1926, Malleomyces Pribram 1933, Ristella Prérot 1938, Zuberella Prévot 1938 and Eubacterium Prévot 1938 (Rule 24a).

Relationship to actinomycetes: Placed by Krassilnikov (1949, 220 and 827 ) in the family Mycobacteriaceae, order Mycobacteriales, class Actinomycetes. 
Rhinocladium Saccardo and March. 1885, 65. (A genus of fungi.)

Relationship to actinomycetes:

Rhinocladium dori (de Beurmann and Gougerot) Neveu-Lemaire 1921 , 84.

Discomyces dori (de Beurmann and Gougerot) de Beurmann and Gougerot 1909 , 59.

Actinomyces dori (de Beurmann and Gougerot) Brumpt 1927, 1206. Nocardia dori (de Beurmann and Gougerot) Vuillemin 1931, 284.

Serratia Bizio 1823, 288.

Relationship to actinomycetes:

Serratia corallina Bergey et al. 1923, 93.

Streptothrix corallina (Bergey et al.) Reader 1926, 1.

Proactinomyces corallinus (Bergey et al.) Jensen 1932, 364.

Nocardia corallina (Bergey et al.) Waksman and Henrici 1948, 902.

Spirosoma Migula 1894, 237.

Relationship to actinomycetes:

Spirosoma lingualis (Eisenberg) Migula 1894, 237.

Nocardia lingualis (Eisenberg) Chalmers and Christopherson 1916, 265.

Discomyces lingualis (Eisenberg) Brumpt 1922, 980.

Actinomyces lingualis (Eisenberg) Sartory and Bailly 1923, 252.

Sporotrichum Link 1824, 1. (A genus of fungi.)

Relationship to actinomycetes:

Sporotrichum minutissimum (Burchardt) Saccardo 1886, 100.

Discomyces minutissimus (Burchardt) B rumpt 1910, 863.

Nocardia minutissima (Burchardt) Verdun 1912 (according to Dodge $1934,741)$.

Actinomyces minutissimus (Burchardt) Brumpt 1927, 1199.

Proactinomyces minutissimus (Burchardt) Krassilnikov 1941, 80.

Sporotrichum dori de Beurmann and Gougerot 1906, 996.

Discomyces dori (de Beurmann and Gougerot) de Beurmann and Gougerot $1909,59$.

Actinomyces dori (de Beurmann and Gougerot) Brumpt 1927, 1206. Nocardia dori (de Beurmann and Gougerot) Vuillemin 1931, 284.

Trichophyton Malmst. 1848 (according to Saccardo 1913, 1334). (A genus of fungi.)

Trichophytum Clements and Shear 1931, 410 (a later orthographic variant (Appendix B, (c)1, Bact. Code) of Trichophyton Malmst.).

Relationship to actinomycetes:

Trichophyton minimum Le Calve and Malherbe 1899, 218.

Actinomyces minimus (Le Calve and Malherbe) Dodge 1935, 728. 
Trichophytum Clements and Shear 1931, 410 (a later orthographic

variant (Appendix B, (c)1, Bact. Code) of Trichophyton Malmst., g. v..).

Trichothecium Link 1824, 28. (A genus of fungi.)

Relationship to actinomycetes:

Trichothecium sp. Neumann 1868 (according to Dodge 1935, 741).

Discomyces minutissimus (Burchardt) Brumpt 1910, 863.

Nocardia minutissima (Burchardt) Verdun 1912 (according to Dodge 1935,741 ).

Actinomyces minutissimus (Burchardt) Brumpt 1927, 1199.

Proactinomyces minutissimus (Burchardt) Krassilnikov 1941, 80. 


\section{BIBLIOGRAPHY}

Affanassieff, M.J. (1887) Aetiologie und klinische Bakteriologie des Keuchhustens. St. Petersb. Med. Wschr. 12(N. F. 4): 323-327, $331-333,339-341,347-350$.

. (1888) Ueber die klinische Mikroskopie und Bacteriologie der Actinomycosis. St. Petersb. Med. Wschr. 13: 76-78, 83-86. and Schulz. (1889) Ueber die Aetiologie der Actinomycosis. Zbl. Bakt. 5: 683-684.

Allen, O.N. and Mrs. O.N. Allen. (1939) Genus Rhizobium Frank, in Bergey et al., Bergey's Manual of Determinative Bacteriology. The Williams and Wilkins Co., Baltimore. 5th ed. 87-92.

Bacteriological Code (see Editorial Board of the International Committee on Bacteriological Nomenclature).

Baldacci, Elio (1939) Introduzione allo studio degli Attinomiceti. Mycopathologia 2: 84-106.

. (1947) Die Systematik der Actinomyceten. Mycopathologia $\underline{4}$ : $60-84$.

(1959) The Extension of the Classification of Actinomycetes. Mikrobiologiia 28: 274-286.

Battaglia, M. (1938) Eumyces tuberculosis. Soc. int. Microbiol., Boll. Sez. ital. 10: 166-171.

Becker, Elery R. (1951) The Legitimacy of Certain Generic Homonyms in Bacteriology and Protozoology. Intern. Bull. Bact. Nomen. and Taxon. 1: $103-112$.

Beijerinck, M.W. (1901) Sur les Ferments Lactiques de 1'Industrie. Arch. néerl. Sci. (Sér. II) $\underline{6}: 212-243$.

- (1913) Ueber Schrobter und Cohn's Lakmusmicrococcus. Folia

Microbiol., Delft 2: 185-200.

. (1914, Dec.) Ueber das Nitratferment und ueber physiologische Artbildung. Folia Microbiol., Delft 3: 91-113. and A. van Delden. (1903) Ueber eine farblose Bakterie, deren

Kohlenstoffnahrung aus der atmosphärischen Luft herrührt. Zbl. Bakt., Abt. 2. 10:33-47.

Bellisari, G. (1904) Sulla presenza e sulla patogenità di streptotricee nelle polveri, residui di cereali. Ann. Igiene (sper.) 14: 467-483.

Bergey, David H., Francis C. Harrison, Robert S. Breed, Bernard W. Hammer and Frank M. Huntoon. (1923) Bergey's Manual of Determinative Bacteriology. The Williams and Wilkins Co., Baltimore. lst ed. $1-442$.

ative Bac' ' ' ' ' (1925) Berilla ed. $1-462$.

' ' (1930) Bergey's Manual of Deter3 rd ed. $1-589$. 
, Robert S. Breed, Bernard W. Hammer, Frank M. Huntoon, E. G. D. Murray and Francis C. Harrison. (1934) Bergey's Manual of Determinative Bacteriology. The Williams and Wilkins Co., Baltimore. 4th ed. 1-664.

, E.G. D. Murray and A. Parker Hitchens. (1939) Bergey's Manual of Determinative Bacteriology. The Williams and Wilkins Co., Baltimore. 5th ed. 1-1032.

Bergonzini, Curzio (1879) I Bacteri. Annu. Soc. Nat. Modena Ser. 2, 13: $19-100$.

- (1881) Sopra un Nuovo Bacterio Colorato. Ann. Soc. Nat. Modena Ser. 2, 14: 149-158.

Billet, Albert (1890) Contribution a l'Étude de la Morphologie et du Développement des Bactériacées. Extr. Bull. Sci. Fr. Belg., Paris. $1-287$.

Billroth, Theodor (1874) Untersuchungen über die Vegetationsformen von Coccobacteria septica. Georg Reimer, Berlin.

Bisset, K.A. and F.W. Moore. (1949) The Relationship of Certain Branched Bacterial Genera. J. gen. Microbiol. 3: 387-391. J. $\frac{}{\text { gen. Microbiol. } \frac{4}{4} \text { (1950). } 280 \text {. }}$ A New Genus of the Actinomycetales.

Bizio, B. (1823) Polenta porporp. Biblioteca italiana o sia Giornale di lettera, scienza ed arti. (Anno VIII.) 30: 275 (according to Buchanan 1925, 535); Lettera di Bartolomeo Bizio al chiarissimo canonico Angelo Bellani sopra il fenomeno della polenta porporina p. 288 - Eng. trans. by Merlino, J. Bact. 9: 538, 1924 (according to Breed 1951, 95).

Blanchard, Raphael (1896) Parasites Végétaux a l'Exclusion des Bactéries, in Bouchard, Ch. Traité de Pathologie Générale. G. Masson, Paris. 2 : $811-926$.

Bokor, Rūololf (1930) Mycococcus cytophagus n. sp. 1929. (Spirochaeta cytophaga Hutchinson and Clayton 1919). Untersuchungen über aerobe, bakterielle Cellulosezersetzung mit besonderer Berücksichtigung des Waldbodens. Arch. Mikrobiol. 1: 1-34.

Borrel, A., Dujardin-Beaumetz, Jeantet and Ch. Jouan. (1910) Le microbe de la Péripneumonie. Ann. Inst. Pasteur 24: 168-179.

Botanical Code (see Lanjouw et al.).

Breed, Robert S. (1948a) Genus Sarcina Goodsir, in Breed et al., Bergey's Manual of Determinative Bacteriology. The Williams and Wilkins Co., Baltimore. 6th ed. 285-294.

. (1948b) Appendix III, Genus Lactobacillus Beijerinck, in Breed et al., Bergey's Manual of Determinative Bacteriology. The Williams and Wilkins Co., Baltimore. 6th ed. 367-369.

. (1948c) Genus Flavobacterium Bergey et al., in Breed et al., Bergey's Manual of Determinative Bacteriology. The Williams and Wilkins Co., Baltimore. 6th ed. 427-442.

- (1951) Incorrect Spellings of Scientific Names and Epithets Used for Bacteria. Intern. Bull. Bact. Nomen. and Taxon. 1: 86-96. 
- (1953) The Brevibacteriaceae Fam. Nov. of Order Eubacteriales.

Rias s. Comun. VI Congr. int. Microbiol., Roma 1: 13-14.

- (1957) Family Corynebacteriaceae Lehmann and Neumann

(Definition and key with arrangement of genera in family), in Breed et al., Bergey's Manual of Determinative Bacteriology. The Williams and Wilkins Co., Baltimore. 7th ed. 578 and 579.

and Heiner Hoffman. (1957) Genus Sphaerophorus Prévot, in Breed et al., Bergey's Manual of Determinative Bacteriology. The Williams and Wilkins Co., Baltimore. 7th ed. 44l-450.

- Erwin F. Lessel, Jr. and Eleanore Heist Clise. (1957) Genus

Pasteurella Trevisan, in Breed et al., Bergey's Manual of Determinative Bacteriology. The Williams and Wilkins Co., Baltimore. 7th ed. 395-402.

, E.G. D. Murray and A. Parker Hitchens. (1948) Bergey's Manual of Determinative Bacteriology. The Williams and Wilkins Co., Baltimore. 6th ed. 1-1529. and Carl S. Pederson (1948) Genus Lactobacillus Beijerinck,

Appendix II. in Breed et al., Bergey's Manual of Determinative Bacteriology. The Williams and Wilkins Co., Baltimore. 6th ed. 364-367.

Bruce, David (1893) Sur une Nouvelle Forme de Fièvre Rencontrée sur les Bords de la Méditerrannée. Ann. Inst. Pasteur 7: 289-304.

Brumpt, Émile (1905) Comp. Rend. 158: 997 (according to Clements and Shear 1931,410).

- (1906) Les Mycétomes. Arch. Parasit., Paris 10: 489-572.

- (1910) Précis de Parasitologie. Masson and Co., Paris. 1st ed. $1-915$.

. (1913) Précis de Parasitologie. Masson and Co., Paris. 2nd ed. $1-1011$.

- (1922) Précis de Parasitologie. Masson and Co., Paris. 3rd ed. $1-1216$.

- (1927) Précis Parasitol. 4th ed. (according to Dodge 1935, 741 and 762).

Buchanan, R.E. (1918a) Studies in the Nomenclature and Classification of the Bacteria. V. Subgroups and Genera of the Bacteriaceae. J. Bact. 3: 27-61.

- (1918b) Studies in the Nomenclature and Classification of the Bacteria. VI. Subdivisions and Genera of the Spirillaceae, and Nitrobacteriaceae. J. Bact. 3: 175-18 !.

- (1918c) Studies in the Classification and Nomenclature of the Bacteria. VII. The Subgroups and Genera of the Chlamydobacteriales. J. Bact. 3: 301-306.

- (1925) General Systematic Bacteriology. The Williams and Wilkins Co., Baltimore. 1-597.

- (1959) The International Code of Nomenclature of the Bacteria and Viruses. Syst. Zool. $\underline{8}:$ 27-39.

Bumm, E. (1885) Der Mikroorganismus der Gonorrhoischen Schleimhaut Erkiankungen, "Gonococcus-Neisser." Wiesbaden (according to Buchanan 1925, 291 and 537). 
Burkholder, Walter H. (1948) Genus Corynebacterium Lehmann and Neumann 1896 (in part), in Breed et al., Bergey's Manual of Determinative Bacteriology. The Williams and Wilkins Co., Baltimore. 6th ed. 392-400.

Burrill, T.J. (1883) New Species of Micrococcus (Bacteria). Amer. Nat. 17: 319-320.

Castellani, Aldo(1911) Trichomycosis flava, nigra and rubra of the Axillary Regions. Brit. J. Derm. 23: 341-344, and Albert J. Chalmers. (1919) Manual of Tropical Medicine. William Wood and Co., New York. 3rd ed. 1-2436. , MacKenzie Douglas and T. Thomson. (1921) Notes on certain forms of bronchitis clinically resembling tuberculosis: bronchohemisporosis, bronchomoniliasis, bronchoanaeromycosis. J. trop. Med. (Hyg.) 24: 149-152.

Chalmers, Albert J. and J.B. Christopherson. (1916) A Sudanese Actinomycosis. Ann. trop. Med. Parasit. 10: 223-282.

Chester, Frederick D. (1901) A Manual of Determinative Bacteriology. The Macmillan Co., New York. 1-401.

Chorine, V. (1929a) New Bacteria Pathogenic to the Larvae of Pyrausta nubilalis $\mathrm{Hb}$. Intern. Corn Borer Invest. (Sci. Rep.). 2: 39-53.

. (1929b) Nouveaux Microbes Pathogènes Pour les Chenilles de la Pyrale du Mais. Ann. Inst. Pasteur 43: 1657-1678.

Clements, Frederick E. and Cornelius L. Shear. (1931) The Genera of Fungi. H.W. Wilson Co., New York. 1-496.

Clise, Eleanore Heist. (1948) Genus Pasteurella Trevisan, in Breed et al. , Bergey's Manual of Determinative Bacteriology. The Williams and Wilkins Co., Baltimore. 6th ed. 546-554.

Cohn, Ferdinand (1872) Untersuchungen über Bacterien. Beitr. Biol. Pf1. 1(Heft II): 127-224.

- (1875) Untersuchungen über Bacterien. II. Beitr. Biol. Pfl. $\underline{1}$ (Heft III): $141-207$.

Conn, H.J. (1928) A Type of Bacteria Abundant in Productive Soils, but Apparently Lacking in Certain Soils of Low Productivity. Tech. Bull. N.Y. St. agric. Exp. Sta., No. 138:3-36.

- (1942) Validity of the Genus Alcaligenes. J. Bact. 44: 353-360. and Isabel Dimmick. (1947) Soil Bacteria Similar in Morphology

to Mycobacterium and Corynebacterium. J. Bact. 54: 291-303.

Corda, August C.J. (1839) Pract-Flora Europaeischer Schimmelbildungen. Gerhard Fleischer, Leipzig and Dresden. 1-55.

Couch, John N. (1950) Actinoplanes, a New Genus of the Actinomycetales. J. Elisha Mitchell sci. Soc. 66: 87-92.

- (1955) A New Genus and Family of the Actinomycetales, with a

Revision of the Genus Actinoplanes. J. Elisha Mitchell sci. Soc. 71: $148-155$.

Cummins, C.S. and H. Harris. (1958) Studies on the Cell-Wall Composition and Taxonomy of Actinomycetales and Related Groups. J. gen. Microbiol. 18: 173-189. 
Cushman, Joseph A. (1933) Some New Foraminiferal Genera. Contr. Cushman Lab. 9: 32-38.

Czaplewski. (1900) Zur Bacteriologie der Lymphe. Dtsch. med. Wschr. 26: $720-723$.

Dangeard, P. -A. (1889) Mémoire sur les Chytridinées. Botaniste l: 39-74.

Davaine, C. (1868) Bactérie. Bactéridie. Dict. Encycl. Sci. méd. 8: $13-39$.

de $\bar{B}$ eurmann and Gougerot. (1906) Les Sporotrichoses Hypodermiques. Ann. Derm. Syph., Paris. 4th Ser., 7: 993-1006.

$7 6 2 \longdiv { \text { . } }$ - (1909) Les Nouvelles Mycoses (according to Dodge 1935,

de Mello, Froilano and António S. Ana Pais. (1918) Um Caso de Nocardiose Pulmonar Simulando a Tísica. Arch. Hyg. Path. exot., Lisboa. 6: 133-206.

de Necker, Nat. (Noel) Jos. (1791) Elementa Botanica. 1: 1-389.

de Toni, J. Bapt. (1897) Intorno alla vita ed alle opere di Vettore Trevisan. Naturalista Padovano. Rend. reale ist. lombardo Sci. Ser. II. 30: $1317-1345$.

. (1907) Myxophyceae. Syll. Algarum 5: 1-761.

and V. Trevisan. (1889) Schizomycetaceae Naeg., in Saccardo, P.A. Syll. fung. 8: $923-1087$.

Dienes, Louis (1948) Supplement No. 3, Pleuropneumonia and Pleuropneumonia-Like Organisms (Borrelomycetaceae), in Breed et al., Bergey's Manual of Determinative Bacteriology. The Williams and Wilkins Co., Baltimore. 6th ed. 1287-1296.

Distaso, A. (1912) Contribution à $1^{\prime}$ étude sur $1^{\prime}$ intoxication intestinale. Zbl. Bakt., Abt. 1, Orig. 62: 433-468.

Dodge, Carroll William (1935, Aug.) Medical Mycology. C. V. Mosby Co., St. Louis. 1-900.

Duclaux, E. (1882) Mémoire sur le Lait. Ann. Inst. nat. agron., Paris (4 ${ }^{\mathrm{e}}$ Année: 1879-1880). 5: 23-138.

Eberson, Frederick (1918) A Bacteriologic Study of the Diphtheroid Organisms with Special Reference to Hodgkin's Disease J. infect. Dis. 23: 1-42.

Editoria1 Board of the International Committee on Bacteriological Nomenclature (1958) International Code of Nomenclature of Bacteria and Viruses. Iowa State Univ. Press, Ames, Iowa. i-xxii, 1-186.

Eggerth, Arnold H. (1935) The Gram-positive Non-spore-bearing Anaerobic Bacilli of Human Feces. J. Bact. 30: 277-299.

Ehrenberg, Christian Gottfried (1828) Symbolae Physicae seu Icones et Descriptiones animalium evertebratorum sepositis insectis quae ex itinere per Africum Borealem et Asiam occidentalem. IV. Evertebrata. Berlin. 
- (1835) Dritter Beitrag zur Erkenntniss grosser Organisation in der Richtung des kleinsten Raumes. Physikal. Abhandl. d. Königl. Akad. d. Wissensch. zu Berlin - Aus dem Jahre 1833. 145-336.

- (1848) Hr. Ehrenberg zeigte das seit alter Zeit berühmte Prodigium des Blutes im Brode und auf Speisen als jetzt in Berlin vorhandene Erscheinung im frischen Zustande vor und erlaüterte dieselbe als bedingt durch ein bisher unbekanntes monadenartiges Thierchen (Monas? prodigiosa). Bericht über die zur Bekanntmachung geigneten Verhandlungen der Konigl. Preuss. Akademie der Wissenschaften zu Berlin. 349-362.

Enderlein, Günther (1917a) Einige neue Bakterien aus der Verwandtschaft des Diphtherie - Erregers. S.B. Ges. naturf. Fr. Berl. Jahr. 1916. 395-406.

- (1917b) Ein neues Bakteriensystem auf vergleichend morphologischer Grundlage. S.B. Ges. naturf. Fr. Berl. Jahr. 1917. 309319.

- (1925) Bakterien - Cyclogenie. Walter de Gruyter and Co., Berlin and Leipzig. 1-390.

Engler, Adolf (1907) Syllabus der Pflanzenfamilien. Borntraeger Brothers, Berlin. 5th ed. 1-247.

Enlows, Ella M.A. (1920) The Generic Names of Bacteria. Treasury Dept. U.S. Publ. Hlth. Serv. Government Printing Office, Washington, D.C. Hygienic Laboratory - Bul1. No. 121: 1-115.

Eppinger, Hans (1891) Ueber eine neue, pathogene Cladothrix und eine durch sie hervorgerufene Pseudotuberculosis (cladothrichica). Beitr. path. Anat. (Ziegler) 9: 287-328.

Evans, Alice C. (1923) The Nomenclature of the Melitensis - Abortus Group of Bacterial Organisms. Publ. Hlth. Rep., U.S. Publ. Hlth. Serv. 38: 1943-1948.

Fischer, Alfred (1895) Untersuchungen über Bakterien. Jb. wiss. Bot. 27: 1-163.

Flïgge, Karl Georg Friedrich Wilhelm (1886) Die Mikroorganismen. F.C.W. Vogel, Leipzig. 2 Aufl. : 1-692.

Ford, William W. (1927) Text-Book of Bacteriology. W.B. Saunders Co., Philadelphia and London. 1-1069.

Foster, Jackson W. (1951) Autotrophic Assimilation of Carbon Dioxide, in Werkman, C.H. and P. W. Wilcon. Bacterial Physiology. Academic Press Inc., N. Y. 361-403.

Foulerton, A.G.R. (1905) New Species of Streptothrix isolated from the Air. [Published in an anonymous report of a meeting of the Pathological Society of London.] Lancet 1: 1199-1200.

Frank, B. (1879) Ueber die Parasiten in den Wurzelanschwellungen der Papilionaceen. Bot. Ztg. 37: 377-388; 393-400.

. (1889) Ueber die Pilzsymbiose der Leguminosen. Ber. dtsch. bot. Ges. 7 : 332-346.

Frankland, Grace C. and Percy F. Frankland (1889) Ueber einige typische Mikroorganismen im Wasser und im Boden. Z. Hyg. Infektkr. 6: 373-400. 
Fred, Edwin Broun, Ira Lawrence Baldwin and Elizabeth McCoy. (1932) Root Nodule Bacteria and Leguminous Plants. Stud. Sci., Wis. Univ. 5: $1-343$.

Freundt, E. A. (1955) The Classification of the Pleuropneumonia Group of Organisms (Borrelomycetales). Intern. Bull. Bact. Nomen. and Taxon. 5: 67-78.

(1957a) Genus Streptobacillus Levaditi et al., in Breed et al., Bergey's Manual of Determinative Bacteriology. The Williams and Wilkins Co., Baltimore. 7th ed. 451-454.

. (1957b) Order Mycoplasmatales Freundt, in Breed et a1., Bergey's Manual of Determinative Bacteriology. The Williams and Wilkins Co., Baltimore. 7th ed. 914-926.

Frosch, P. (1923) Die Morphologie des Lungenseucheerregers. (Eine mikrophotographische Studie.) Arch. wiss. prakt. Tierheilk. 49: $35-48,273-282$.

Gamaleia, N. (1888) Zur Aetiologie der Hühnercholera. Zbl. Bakt. 4: $161-168$.

Gasperini, Gustavo (1892) Ricerche Morfologiche e Biologiche sul Genere Actinomyces - Harz come Contributo allo Studio delle Relative Micosi. Ann. ist. Igiene sper. Univ. Roma. 2: 167-229.

- (1894a) Ulteriori ricerche sul genere Actinomyces. Atti Soc. tosc. Sci. nat. 9: 64-89.

- (1894b) Versuche tiber das Genus 'Actinomyces'. Zbl. Bakt. 15: $684-686$.

Gastinel, Pierre, R. Fasquelle, A. Névot, D. Christol, R. Demanche and P. Nicolle. (1957) Précis de Bactériologie Médicale. Masson and Co., Paris. 2nd ed. 1-1243.

Gay et al. (1935) Agents of Disease and Host Resistance. Charles C. Thomas, Springfield, Ill. and Baltimore, Md. $1-1581$.

Gedoelst, L. (1902) Les Champignons Parasites de 1'Homme et des Animaux Domestiques. Joseph van In and Co., Lierre, Belgium. $1-199$.

Goodsir, John (1842) History of a case in which a fluid periodically ejected from the stomach contained vegetable organisms of an undescribed form. Edinb. med. surg. J. 57: 430-443.

Gray, P.H.H. and H.G. Thornton. (1928) Soil Bacteria that decompose certain Aromatic Compounds. Zbl. Bakt., Abt. 2, 73: 74-96.

Gruber, Max (1893) Mikromyces Hofmanni, eine neue pathogene Hyphomycetenart. Arch. Hyg., Berl. 16: 35-52.

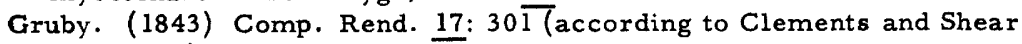
$1931,410)$.

Guéguen, Fernand (1904) Les Champignons Parasites de l'Homme et des Animaux. A. Joanin and Co., Paris. 1-299.

Haass, Everhard (1906) Beitrag zur Kenntnis der Aktinomyceten. Zbl. Bakt., Abt. 1, Orig. 40: 180-186. 
Hagan, William Arthur (1939) Genus Actinobacillus Brumpt, in Bergey et al., Bergey's Manual of Determinative Bacteriology. The $\bar{W}$ illiams and Wilkins Co., Baltimore. 5th ed. 553-555.

- (1943) The Infectious Diseases of Domestic Animals - with Special Reference to Etiology, Diagnosis, and Biologic Therapy. Comstock Publishing Co., Inc., Ithaca, N. Y. 1-665.

- (1948) Genus Actinobacillus Brumpt, in Breed et al., Bergey's Manual of Determinative Bacteriology. The Williams and Wilkins Co., Baltimore. 6th ed. 556-558.

Hallier, Ernst (1870) Die Parasiten der Infectionskrankheiten. Z. Parasitenk. 2: 113-132.

Hanks, John H. (1948) Mycobacterium leprae and $\mathrm{M}$. lepraemurium, in Breed et al. , Bergey's Manual of Determinative Bacteriology. The Williams and Wilkins Co., Baltimore, 6th ed. 881-883.

Hartleb. (1900) Die Morphologie und systematische Stellung der sogen. Knöllchenbakterien. Chemikerztg. 2: 887-888.

Harz, C.O., in O. Bollinger. (1877) Üeber eine neue Pilzkrankheit beim Rinde. Zbl. med. Wiss. 15: 481-485.

- (1879) Actinomyces bovis, ein neuer Schimmel in den Geweben des Rindes. Jahresb; k. Cent. Thierärzn. Schule München. (18771878). $125-140$.

Hauduroy, Paul (1947) Microbiologie générale et Technique microbiologique. Masson and Co. 1-623.

, G. Ehringer, Ach. Urbain, G. Guillot and J. Magrou. (1937) Dictionnaire des Bactéries Pathogènes. Masson and Co., Paris. $1-597$.

, G. Guillot, Magrou, A. -R. Prévot, Rosset and Urbain. (1953) Dictionnaire des Bactéries Pathogènes. Masson and Co., Paris. 2nd ed. 1-692.

Haupt, H. (1957) Genus Actinobacillus Brumpt, in Breed et al., Bergey's Manual of Determinative Bacteriology. The Williams and Wilkins Co., Baltimore. 7th ed. 414-418.

Hauser, Gustav (1885) Über Faulnissbacterien und deren Beziehungen zur Septicămie (Ein Beitrag zur Morphologie der Spaltpilze). F. C.W. Vogel, Leipzig. 1-94.

Heilman, Fordyce R. (1941) A Study of Asterococcus muris (Streptobacillus moniliformis). J. infect. Dis. 69: 32-44.

Henssen, A. (1957) Beitrăge zur Morphologie und Systematik der thermophilen Actinomyceten. Arch. Mikrobiol. 26: 373-414.

Hlava, J. (1889) Studie o tyfu skvrnitém. (Sur le typhus [t. exanthematicus].) Sbornik Lekarsky v. Praze (Archives bohemes de medecine clinique). 3: 122-183.

Hoelling, A. (1910) Die Kernverhältnisse von Fusiformis termitidis. Arch. Protistenk. 19: 239-245.

Holland, Dorothy F. (1920) V. Generic Index of the Commoner Forms of Bacteria (pp. 215-229), in Winslow, C. -E. A., Jean Broadhurst, R.E. Buchanan, Charles Krumwiede, Jr., L. A. Rogers and G.H. Smith. The Families and Genera of the Bacteria. J. Bact. 5: $191-229$. 
Hucker, G.J. and Eleanore Heist Clise. (1948) Genus Micrococcus Cohn, Appendix III, in Breed et al., Bergey's Manual of Determinative Bacteriology. The Williams and Wilkins Co., Baltimore. 6th ed. 250-282.

Hughes, M. Louis (1892) The Natural History of Certain Fevers occuring ( $\mathrm{sic})$ in the Mediterranean. Mediter. Nat. 2: 299-300, 325-327, $332-\overline{334}$.

Hutchinson, Henry Brougham and James Clayton. (1919) On the Decomposition of Cellulose by an Aerobic Organism (Spirochaeta cytophaga, n. sp.). J. agric. Sci. 9: 143-173.

Jacqué, Léon and Fernand Masay. (1912) Le Streptobacterium foetidum, agent pathogène nouveau de $1^{\prime}$ homme, $\mathrm{Zbl}$. Bakt., Abt. l, Orig. 62: 180-186.

Jahn, E. (1906) Myxomycetenstudien. Ber. dtsch. bot. Ges. 24: 538541.

Janke, Alexander (1930) Zur Bakterien-Systematik. Zbl. Bakt., Abt. 2, 80: 481-492.

Jensen, H. L. (1931) Contributions to our Knowledge of the Actinomycetales. II. The Definition and Subdivision of the Genus Actinomyces, with a Preliminary Account of Australian Soil Actinomycetes. Proc. Linn. Soc. N.S.W. 56: 345-370.

. (1932) Contributions to our Knowledge of the Actinomycetales.

IV. The Identity of Certain Species of Mycobacterium and Proactinomyces. Proc. Linn. Soc. N.S.W. 57: 364-376.

- (1934) Studies on Saprophytic Mycobacteria and Corynebacteria. Proc. Linn. Soc. N.S.W. 59: 19-61.

Johansen, Alfhild E. (1945) A New Mycelioid Chytrid: Myceliochytrium fulgens Gen. nov. et Sp. nov. Torreya 45: 104-105.

Judicial Commission (1953) Status of Generic Names of Bacteria Proposed by Trevisan. Preliminary Statement. File 56. Intern. Bull. Bact. Nomen. and Taxon. 3: 87-108.

- (1954a) Opinion 4 (Revised). Rejection of the Generic Name Bacterium. Intern. Bull. Bact. Nomen. and Taxon. 4: 141-142.

- (1954b) Opinion 12. Conservation of Listeria Pirie 1940 as a Generic Name in Bacteriology. Intern. Bull. Bact. Nomen. and Taxon. 4: 150-151.

- (1954c) Opinion 13. Conservation and Rejection of Names of Genera of Bacteria Proposed by Trevisan 1842-1890. Intern. Bull. Bact. Nomen. and Taxon. 4: 151-156.

- (1954d) Opinion 14. Names of Bacterial Genera to be Rejected as later synonyms of Names of Genera of Protozoa. Intern. Bull. Bact. Nomen. and Taxon. 4: 156-158.

. (1955) The Status and Synonymy of the Bacterial Generic Name Asterococcus. Preliminary Statement. Intern. Bull. Bact. Nomen. and Taxon. 5: 13-20. 
- (1958a) Opinion 16. Conservation of the Generic Name Chromobacterium Bergonzini 1880 and Designation of the Type Species and the Neotype Culture of the Type Species. Intern. Bull. Bact. Nomen. and Taxon. 8: 151-152.

- $(1958 \mathrm{~b})$ Opinion 20. Status of New Generic Names of Bacteria Published Without Names of Included Species. Intern. Bull. Bact. Nomen. and Taxon. 8: 160-162.

- (1958c) Opinion 22. Status of the Generic Name Asterococcus and Conservation of the Generic Name Mycoplasma. Intern. Bull. Bact. Nomen. and Taxon. 8: 166-168.

- (1958d) Opinion 23. Rejection of the Generic Names Nitromonas Winogradsky 1890 and Nitromonas Orla-Jensen 1909, Conservation of the Generic Names Nitrosomonas Winogradsky 1892, Nitrosococcus Winogradsky 1892, and Nitrobacter Winogradsky $1892, \overline{\text { and }}$ the Designation of the Type Species of these Genera. Intern. Bull. Bact. Nomen. and Taxon. 8 : 169-170.

(1958e) Opinion 24. Rejection of the Generic Name Arthrobacter Fischer 1895 and Conservation of the Generic Name Arthrobacter Conn and Dimmick 1947. Intern. Bull. Bact. Nomen. and Taxon. 8 : $171-172$.

Kellerman, K.F., I. G. McBeth, F.M. Scales and N.R. Smith. (1913) Identification and Classification of Cellulose-Dissolving Bacteria. Zbl. Bakt., Abt. 2, 39: 502-522.

Kent, W. Saville (1880) A Manual of the Infusoria: Including a Description of All Known Flagellate, Ciliate, and Tentaculiferous Protozoa, British and Foreign, and an Account of the Organization and Affinities of the Sponges. David Bogue, London. 1: 1-472.

Kirchner O. (1896) Die Wurzelknöllchen der Sojabohne, in Cohn, Beitr. Biol. Pfl. 7(Heft II): 213-224.

Kisskalt, Karl and Ē̄ith Berend. (1918) Untersuchungen über die Gruppe der Diphtheröiden (Corynbakterien). Zbl. Bakt., Abt. 1, Orig. 81: 444-447.

Kitt, Th. (1893) Bacterienkunde und Pathologische Mikroskopie für Thierärzte und Studirende der Thiermedicin. Moritz Perles, Wien. 2 Auf1. $1-450$.

Klebs, Edwin (1871) Die Ursachen der infectiösen Wundkrankheiten. Cor. -Bl. f. shweiz. Aerzte (according to Buchanan 1925, 545).

K1ein, Edward Emanuel (1884a) Micro-organisms and Disease. Practitioner 32: 170-186, 241-264, 321-352, 401-426. - (1884b) Micro-organisms and Disease (Continued from vol. xxxii. p. 426.). Practitioner 33: 21-40, 81-112, 161-180, 241-254. - (1908) On the Nature and Causes of Taint in Miscured Hams (Bacillus foedans). Lancet $1: 1832-1834$.

Kluyver, A.J. and C.B. van Niel. (1936) Prospects for a natural system of classification of bacteria. Zbl. Bakt. 94: 369-403.

Koch, Robert (1882) Die Aetiologie der Tuberculose. Berl. klin. Wschr. 19: 221-230. 
- (1884) Die Aetiologie der Tuberkulose. Mitt. k. Gesundheit. 2: $1-88$.

Krainsky, A. (1914) Die Aktinomyceten und ihre Bedeutung in der Natur. Zbl. Bakt., Abt. 2, 41: 649-688.

Krassilnikov, N A. (1938a) Proactinomyces. Bull. Acad. Sci. U.S.S.R. No. I: 139-172.

- (1938b) A New Genus of "Actinomycetales" - Mycococcus n. gen. Mikrobiologiia 7(Part 1): 335-352.

. (1941) Guide to the Actinomycetes. Izd. Akad. Nauk, U.S.S.R., Moscow. 1-148.

. (1945) The Classification of Actinomycetales. Mikrobiologiia. 14: $164-171$.

. (1949) Guide to the Bacteria and Actinomycetes. Izd. Akad. Nauk, U.S.S.R., Moscow. 1-830.

Kruse, W. (1896a) Systematik der Streptothricheen, in Flügge, C. Die Mikroorganismen. F.C.W. Vogel, Leipzig. 3 Aufl. 2: 48-66. - (1896b) Systematik der Bakterien, in Flügge, C., Die Mikroorganismen. F.C.W. Vogel, Leipzig. 3 Aufl., 2: 67-96, 185-526. Kutzing, Friedrich Traugott (1833) Sphaerotilus natans, eine neue Süsswasseralge. Linnaea $8: 385-387$.

- (1843) Phycologia Geñeralis (oder Anatomie, Physiologia und Systemkunde der Tange). F. A. Brockhaus, Leipzig. 1-458. - (1849) Species Algarum. F.A. Brockhaus, Leipzig. 1-922.

Labbé, Alphonse (1896) Recherches Zoologiques, Cytologiques et Biologiques sur les Coccidies. Arch. Zool. exp. gén. 4: 517-654. . (1899) Sporozoa, in Das Tierreich. 1(5. Lieferung): 1-180. Lahelle, O. and Th. Thjötta. (1945) A Systematic Study of Fusobacterium and Necrobacterium (i.e. Actinomyces necrophorus, Nekrosebacillus Bang) as to their Biological Relationships and Proposal of a New and Adequate Name for the Latter. Acta path. microbiol. Scand. 22: 310-322.

Lang, Eduard ( $\overline{1879}$ ) Vorlaufige Mittheilung von einem neuen Untersuchungsergebnisse bei Psoriasis. Arch. Derm. Syph., Wien 1l: 257-263.

Langeron, Mauric (1922) Les Oosporoses. Nouv. Traité de Méd. Fasc. IV: $430-447$.

Lanjouw, J., Ch. Baehni, W. Robyns, R.C. Rollins, R. Ross, J. Rousseau, G.M. Schulze, A.C. Smith, R. de Vilmorin, and F.A. Stafleu. (1956) International Code of Botanical Nomenclature. Intern. Bur. for Plant Tax. and Nom. of the Intern. Assoc. for Plant Tax., Utrecht, Netherlands. 1-338.

Lantzsch, Kurt (1922) Actinomyces oligocarbophilus (Bacillus oligocarbophilus Beij.), sein Formwechsel und seine Physiologie. $\mathrm{Zbl}$. Bakt., Abt. 2, 57: 309-319.

Le Calvê and H. Malherbe. (1899) Sur un Trichophyton du Cheval: A Cultures Lichénöides (Trichophyton minimum). Arch. Parasit. 2: 218-250. 
Lechevalier, Mary P. and H. Lechevalier. (1957, Aug. 23) A New Genus of the Actinomycetales: Waksmania gen. nov. J. gen. Microbiol. 17: 104-111.

Ledingham, J.C.G. (1933) The Growth Phases of Pleuropneumonia and Agalactia on Liquid and Solid Media. J. Path. Bact. 37: 393-410.

Lehmann, K. B. and Rudolf Neumann. (1896). Lehmann's Med. Handatlanten, X. Atlas und Grundriss der Bakteriologie und Lehrbuch der speciellen bakteriologischen Diagnostik. J.F. Lehmann, München. 1 Aufl., 2: 1-448.

- (1899) Lehmann's Medecin. Handatlanten, X. Atlas und Grundriss der Bakteriologie und Lehrbuch der speziellen bakteriologischen Diagnostik. J.F. Lehmann, München, 2 Aufl., 2: 1-495. - (1907) Lehmann's Medezin. Handatlanten, $\bar{x}$. Atlas und Grundriss der Bakteriologie und Lehrbuch der speziellen bakteriologischen Diagnostik. J.F. Lehmann, München, 4 Aufl., 2: 1-730. - (1927) Bakteriologie insbesondere bakteriologische Diagnostik. J.F. Lehmann, München, 7 Aufl. 2: 1-876.

Leube, W. (1885) Ueber die ammoniakalische Harngährung. Virchows Arch. 100: 540-570.

Levaditi, C., S. Nicolau and P. Poincloux. (1925) Sur le rôle étiologique de Streptobacillus moniliformis (nov. spec.) dans l'érythème polymorphe aigu septicémique. C.R. Acad. Sci., Paris 180: 1188 1190.

Levy, E. (1899) Ueber die Actinomycesgruppe (Aktinomyceten) und die ihr verwandten Bakterien. Zbl. Bakt., Abt. 1, 26: 1-11.

Lewandowsky, Felix (1904) Die Pseudodiphtheriebacillen und ihre Beziehungen zu den Diphtheriebacillen. Zbl. Bakt., Abt. 1, Orig. 36: $336-351,472-480$.

Lewkowicz, Xavier (1901) Recherches sur la Flore Microbienne de la Bouche des Nourrissons. Arch. Méd. exp. 13: 633-660.

Lieske, Rudolf (1921) Morphologie und Biologie der Strahlenpilze (Actinomyceten). Borntraeger Brothers, Leipzig. 1-292.

Lignières, José (1924) Nouvelle Contribution a l'Etude des Champignons Produisant les Actinomycoses. Ann. Parasit. hum. comp. 2: $1-25$.

and Jorge Spitz. (1902a) Contribution a 1'Étude des Affections Connues sous le Nom d'Actinomycose - Actinobacillose. Rev. Soc. med. argent. 5-105.

- (1902b) Contribución al estudio de las afecciones conocidas bajo el nombre de actinomicosis - Actinobacilosis. Bol. Agric. Ganad., B. Aires 11: 169-229.

- (1902c) L'Actinobacillose. Bull. Soc. cent. Méd. vét.

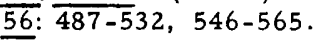
32: $932-976$. . (1902d) Aktinobacilloz. Arkh. vet. Nauk, St. Petersb. - (1903) Contibution a l'Étude des Affections Connues sous le Nom d'Actinomycose. Arch. Parasit. 7: '428-479. 
- (1904) Contribution à l'étude, à la classification et à la nomenclature des affections connues sous le nom d'actinomycose. Zbl. Bakt., Abt. 1, Orig. 35: 294-308; 452-458.

Link. (1824) Sp. Pl. Fung. $\overline{1: 1}$ and 28 (according to Clements and Shear 1931, 389 and 390).

Lipschütz, B. (1913) Bakteriologischer Grundriss und Atlas der Geschlechtskrankheiten. Johann Ambrosius Barth, Leipzig. 1-123.

Lochhead, A. G. (1955) Brevibacterium helvolum (Zimmermann) comb. nov. Intern. Bull. Bact. Nomen. and Taxon. $\underline{5}$ : 115-119.

Löwi, Emil (1920) Ueber den "Bacillus crassus" Lipschütz. Wien. klin. Wschr. 33: 730-733.

Luerssen, Artur and M. Kühn. (1908) Yoghurt, die bulgarische Sauermilch. Zbl. Bakt., Abt. 2, 20: 234-248.

Lutz, Adolph (1886) Zur Morphologie des Mikroorganismus der Lepra. Derm. Stud., Hamburg 1: 77-100.

Macé, E. (1897) Traité Pratique de Bactériologie. J. -B. Baillière and Sons, Paris. 3rd ed. 1-1144.

- (1901) Traité Pratique de Bactériologie. J. -B. Bailliére and Sons, Paris. 4th ed. 1-1196.

Maggi, Leopoldo (1886) Essai d'une Classification Protistologique des Ferments Vivants. J. Micrographie 10: 80-85, 173-178, 327 333.

Maire, René and Adrien Tison. (1909) La cytologie des Plasmodiophoracées et la classe des Phytomyxinae. Ann. mycol., Berl. 7: 226253.

Manteufel, P. (1937) Neuere Untersuchungen über das vermeintliche Gelbfieberbakterium B. hepatodystrophicans von Kuczynski. Zbl. Bakt., Abt. 1, Orig. 138:306-309.

Martzinovski, E.-J. (1911) De 1'Etiologie de la Péripneumonie. Ann. Inst Pasteur 25: 914-917.

McCulloch, Lucia (1925) Aplanobacter insidiosum n. sp., the cause of an alfalfa disease. Phytopathology 15: 496-497.

Mégnin. (1881) Nouvelle Maladie Parasitaire de la Peau chez un Coq. C.R. Soc. Biol., Paris 33: 404-406.

Merchant, Ival Arthur (1950) Veterinary Bacteriology and Virology. The Iowa State College Press, Ames, Iowa. 4th ed. 1-885.

Merrill, E. D. and H.W. Wade. (1919) The Validity of the Name Dis comyces for the Genus of Fungi Variously Called Actinomyces, Streptothrix and Nocardia. Philipp. J.Sci. 14: 55-69.

Mẹtalnikov, S. and V. Chorine. (1928) Maladies Microbiennes chez les Pyrales de Mais (Pyrausta nubilalis Hübn). Ann. Inst. Pasteur 42: $1635-1660$.

Metschnikoff, Elias (1888) Ueber die phagocytäre Rolle der Tuberkelriesenzellen. Virchows Arch. 113: 63-94.

Meyen, Franz Julius Ferdinand (1 $\overline{827}$ ) Actinomyce, Strahlenpilz. Eine neue Pilz-Gattung. Linnaea 2 2 : 433-444. 
- (1839a) Neues Syst. Pfl. -Physiol. 3: 1-627.

- (1839b) Jahresbericht über die Resultate der Arbeiten im Felde der physiologischen Botanik von dem Jahre 1838. Arch. Naturgesch. 5(2): $1-152$.

Meyer, K.F. and E.B. Shaw. (1920) A Comparison of the Morphologic, Cultural and Biochemical Characteristics of $\underline{B}$. abortus and $\underline{B}$. melitensis - Studies on the Genus Brucella nov. gen. I. J. infect. Dis. 27: $173-184$.

Migula, W. (1894) Ueber ein neues System der Bakterien. Arb. Bact. Inst. Karlsruhe. 1: 235-238 (according to Buchanan 1925, 550). - (1900) System der Bakterien. Gustav Fischer, Jena. 2: 1-1068.

Moquin. (1849) Amarantaceae, in de Candolle, Alphonso. Prodromus Systematis Naturalis Regni Vegetabilis. Sectio Posterior. 13: 231424.

Müller, Othone (Otto) Friderico (Friedrich) (1773) Vermium Terrestrium et Fluviatilium, seu Animalium Infusoriorum, Helminthicorum et Testaceorum, non Marinorum, Succincta Historia. 1(pt. 1): 1-135. - (1786) Animalcula Infusoria Fluviatilia et Marina, Quae Detexit, Systematice Descripsit et Ad Vivum Delineari Curavit. 1-367.

Murray, E.G.D. and Robert S. Breed. (1948) Genus Corynebacterium Lehmann and Neumann, in Breed et al., Bergey's Manual of Determinative Bacteriology. The Williams and Wilkins Co., Baltimore. 6th ed. 381-392.

, R.A. Webb and M.B.R. Swann. (1926) A Disease of Rabbits Characterised by a Large Mononuclear Leucocytosis, Caused by a Hitherto Undescribed Bacillus Bacterium monocytogenes (n. sp.). J. Path. Bact. 29: 407-439.

Musgrave, W.E., M. T. Clegg and Mary Polk. (1908) Streptothricosis with special reference to the etiology and classification of mycetoma. Philipp. J. Sci., Ser. B., Med. Sci. 3: 447-544.

Nägeli, Karl (1842) Botanische Beiträge. Linnaea 16: 237-285.

Nannizzi, Arturo (1934) Repertorio Sistematico dei Mic eti dell 'Uomo e degli Animali, in Pollacci, Tratt. di Micopat. Umana. 4: 1-557.

Negroni, P. (1953) Morfologia Microscopica y Sistematica de los Actinomycetes. Actinomycetales - Morfologia, Biologia e Sistematica. Intern. Union biol. Sci. Ser B, No. 4: 13-19.

Nellis, Lois (1957) Genus Mycococcus Krassilnikov, in Breed et al., Bergey's Manual of Determinative Bacteriology. The Williams and Wilkins Co., Baltimore. 7th ed. 707-713.

Neveu-Lemaire. (1906) Précis Parasitol (according to Dodge 1935, 741). - (1921) Précis Parasitol. (according to Dodge 1935, 762).

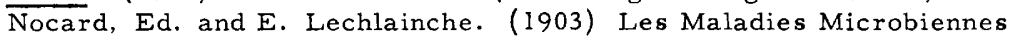
des Animaux. Masson and Co., Paris. 3rd ed. 2: 1-645.

Nonomura, Hideo and Yuwao Ohara. (1957, Aug. 15) Distribution of Actinomycetes in the Soil (II) - Microbispora, a New Genus of Streptomycetaceae. J. Ferment. Tech. (Jap.) 35: 307-311. (English Abstract: p. 28.) 
Nowak, Julien (1929) Morphologie, Nature et Cycle Evolutif du Microbe de la Péripneumonie des Bovidés. Ann. Inst. Pasteur 43: 1330-1352.

Nowakowski, Leon (1876) Beitrag zur Kenntniss der Chytridiaceen, in Cohn, Beitr. Biol. Pfl. 2(Heft I): 73-100.

Ogston, Alex (1883) Micrococcus Poisoning (continued from vol, xvi, p. 567). J. Anat., London 17: 24-58.

Orla-Jensen, S. (1909) Die Hauptlinien des natürlichen Bakteriensystems. Zbi. Bakt., Abt. 2, 22: 305-346.

- (1919) The Lactic Acid Bacteria. K. danske vidensk. Selsk.

Ser. 8, 5(No. 2): 79-196.

- (1920) La Classification des Bactéries Lactiques. Lait $\underline{4}$ : 468474.

Orskov, J. (1923) Investigations into the Morphology of the Ray Fungi. Levin and Munksgaard, Copenhagen. 1-171.

Pacheco, Genesio (1933) A posição sistematica das bacterias das febres ondulantes. Rev. Soc. paul. Med. vet. 3: 1-14.

Parker, Frederic Jr. and N. Paul Hudson. (1926) The Etiology of Haverhill Fever (Erythema Arthriticum Epidemicum). Amer. J. Path. 2: 357-379.

Pederson, Carl S. (1939) Genus Lactobacillus Beijerinck, in Bergey et al., Bergey's Manual of Determinative Bacteriology. The Williams and Wilkins Co., Baltimore. 5th ed. 362-378.

- (1948) Genus Lactobacillus Beijerinck, in Breed et al., Bergey's Manual of Determinative Bacteriology. The Williams and Wilkins Co., Baltimore. 6th ed. 349-364.

- (1957) Genus Lactobacillus Beijerinck, in Breed et al., Bergey's Manual of Determinative Bacteriology. The Williams and Wilkins Co., Baltimore. 7th ed. 542-552.

Perroncito, Eduard (1875) Osteo-sarcoma della mascella anteriore e posteriore nei bovini. Encicl. agr. ital. 3: 599 (according to Waksman 1959b, 304).

- (1879a) Ueber das epizootische Typhoid der Huhner. Arch. wis s. prakt. Tierheilk. 5: 22-51.

- (1879b) Ueber den Actinomyces bovis und die Sarkome der

Rinder. Dtsch. Z. Tiermed. verg. Path. 5: 33-40.

Persoon, C.H. (1794) Einige Bemerkungen uैber die Flechten: Nebst Beschreibungen einiger neuen Arten aus dieser Familie der Aftermoose. Neue Ann. Bot. 1: 1-32.

Petruschky, J. (1896) Bacīlus faecalis alcaligenes (n. sp.). Zbl. Bakt., Abt. 1, 19: 187-191.

- (1903) Die pathogenen Trichomyceten - Streptothrix, Cladothrix, Leptothrix. Handb. path. Mikroorganismen (Kolle und Wassermann). 2: $832-860$.

Pinoy, E. (1911) in Liégard and Landrieu. Un cas de mycose conjunctivale. Bull. Soc. Ophtal. Paris 24: 246-254. 
- (1913) Actinomycoses et Mycétomes. Bull. Inst. Pasteur 11: $929-938,977-984$.

and Morax. (1911) Note sur les concrétions des voies lacrymales. Etude mycologique. Bull. Soc. Ophtal. Paris 24: 95-99.

Pirie, J.H. Harvey (1927) A New Disease of Veld Rodents. "Tiger River Disease." Publ. S. Afr. Inst. med. Res. 3: 163-186.

- (1940) The Genus Listerella Pirie. Science 91: 383.

Porcher, Ch. (1903) Abstracter of: Lignières, J. and Spitz, L'actinobacillose. (Bulletin de la Société Cent. de méd. vét. 1902. 30 Sept.). Zbl. Bakt., Abt. 1, Ref. 32:781-787.

Prazmowski. (1880) Untersuchungen über die Entwicklungsgeschichte und Fermentwirkung einigen Bakterien - Arten. Inaug. Diss., Leipzig (according to Smith 1948, 708).

Preisz, Hugo (1894) Recherches Comparatives sur les Pseudotuberculoses Bacillaires et une Nouvelle Espèce de Pseudotuberculose.

Ann. Inst. Pasteur 8: 231-255.

Prévot, André R. (1938) Etudes de Systématique Bactérienne. Ann. Inst. Pasteur 60: 285-307.

- (1940) Manuel de Classification et de Détermination des

Bactéries Anaérobies. Masson and Co., Paris. 1-223. - (1948) Manuel de Classification et de Détermination des

Bactéries Anaérobies. Masson and Co., Paris. 2nd ed. 1-290. - (1953) Classification, in Hauduroy et al., Dict. d. Bact. Path. Masson and Co., Paris. 2nd ed. 135-141.

Pribram, Ernst (1929) A Contribution to the Classification of Microörganisms. J. Bact. 18: 361-394.

- (1933) Klassifikation der Schizomyceten. Franz Deuticke, Leipzig and Vienna. 1-143.

Puntoni, Vittorio and Domenico Leonardi. (1935) Sulla sistematica degli Attinomiceti Asteroides n.g. Boll. Accad. med., Roma 61: 90-94.

Reader, Vera B. (1926) The Identification of the So-called B. mycoides corallinus as a Streptothrix. J. Path. Bact. 29: 1-4.

Reed, Guilford B. (1939) Genus Mycobacterium Lehmann and Neumann, in Bergey et al. , Bergey's Manual of Determinative Bacteriology. The Williams and Wilkins Co., Baltimore. 5th ed. 809-827.

- (1948) Family Mycobacteriaceae Chester, in Breed et al., Bergey's Manual of Determinative Bacteriology. The Williams and Wilkins Co., Baltimore. 6th ed. 875-891.

Reitz, Adolf (1906) Weitere bakteriologische Untersuchungen mit der Stuttgarter Markt- und Handelsbutter. Zbl. Bakt., Abt. 2, 16: 719 733, 776-794.

Remak, R. (1845) Diagnostische und pathogenetische Untersuchungen. August Hirschwald, Berlin. 1-242.

Rist, Edouard and Joseph Khoury. (1902) Études sur un lait fermenté comestible le "Leben" d'Egypte. Ann. Inst. Pasteur 16: 65-84. 
Rivolta, Sebastiano (1878) Sul così detto mal del rospo del Trutta e sull' actinomyces bovis di Harz. Clin. vet., Milano $\underline{1}$ : 169-176, 201-208.

Robin, Charles (1853) Histoire Naturelle des Végétaux Parasites qui Croissent sur 1'Homme et sur les Animaux Vivants. J. -B. Baillière, Paris. 1-702.

Rosenbach, Friedrich Julius (1884) Mikro-organismen bei den WundInfections-Krankheiten des Menschen.J.F. Bergmann, Wiesbaden. $1-122$.

- (1909) Experimentelle, morphologische und klinische Studie über die krankheitserregenden Mikroorganismen des Schweinerotlaufs, des Erysipeloids und der Măusesepsis. Z. Hyg. Infektkr. 63: 343371 .

Rossi Doria, Tullio (1891) Su di Alcune Specie di "Streptotrix" Trovate nell' Aria Studiate in Rapporto a Quelle Già Note e Specialmente al1" "Actinomyces." Ann. inst. Igiene sper. Univ. Roma 1: 399438 .

Sabin, Albert B. (1941) The Filtrable Microörganisms of the.Pleuropneumonia Group. Bact. Rev. 5: 1-68.

Saccardo, P.A. (1882) Michelia. 2: 639 (according to Saccardo 1886, 11 and Clements and Shear 1931, 387).

- (1886) Sy11. fung. 4: 1-807.

- (1913) Syll. fung. $22^{2}: 823-1612$.

and March. (1885) Bull. Soc. Roy. Bot. Belg. 24: 65 (according to Clements and Shear 1931, 394); Champ. copr. Belg. pag. 33 (according to Saccardo 1886, 295).

Sampietro, G. (1908) Sopra due casi di actinomicosi nell'uomo. Ann. Igiene (sper.) 18: 391-416.

Sartory, A. and A. Bailly. (1923) Mycoses Pulmonaires (according to Dodge 1935, 743).

Sauvageau, Camille-François and M. Radais. (1892) Sur les Genres Cladothrix, Streptothrix, Actinomyces et Description de Deux Streptothrix Nouveaux. (Sur le Genre Oospora.) Ann. Inst. Pasteur $\underline{6: 242-}$ 273 .

Săvulescu, Traian. (1947a) Anal. Acad. Romane, III, 22: 10 (according to Breed, personal communication, 1954).

- (1947b) Plant Pathogenic Bacteria - Their Taxonomy and Nomenclature. Abstr. Commun. IV Congr. int. Microbiol., Copenhagen. $133-135$.

- (1949) Contribution to the Classification of Bacterial Plant Pathogens. Proc. IV Congr. int. Microbiol. (1947). Rosenkilde and Bagger, Copenhagen. 429-431.

Scherffel, A. (1908) Asterococcus n.g. superbus (Cienk.) Scherffel und dessen angebliche Beziehungen zu Eremosphaera. Ber. dtsch. bot. Ges. 26A: 762-771.

Schlegel, M. (1913) Aktinomykose, in Kolle, W: and von Wasserman, A. Handb. path. Mikroorganismen. 2nd ed., 5: 301-364. 
Schottmüller, H. (1914) Zur Ätiologie und Klinik der Bisskrankheit (Ratten-, Katzen-, Eichhörnchen-Bisskrankheit). Derm. Wschr. 58(Supp1.): 77-103.

Schroeter, J. (1872) Ueber einige durch Bacterien gebildete Pigmente. in Cohn. Beitr. Biol. Pfl. 1(Heft 2): 109-126.

. (1886) Pilze, in Cohn, Ferdinand. Kryptogamen-Flora von Schlesien. J.U. Kern, Breslau. $3: 1-814$.

Serbinov, I. L. (1925) Un cas d'actinomycose épidémique des fruits du Capsicum annuum L. P1. Prot., Leningr. 2: 537-546.

Smit, Jan (1930) Die Gärungssarcinen. Pflañzenforschung. Gustav Fischer, Jena. 1-59.

Smith, Erwin F. (1905) Bacteria in Relation to Plant Diseases. Carnegie Inst. Wash. 1: 1-285.

- (1914) Bacteria in Relation to Plant Diseases. Carnegie Inst.

Wash. 3: 1-309.

and C.O. Townsend. (1907) A Plant-Tumor of Bacterial Origin.

Science 25(N.S.): $671-673$.

Smith, Nathan R. (1948) Genus Bacillus Cohn, in Breed et al., Bergey's Manual of Determinative Bacteriology. The Williams and Wilkins Co., Baltimore. 6th ed. 705-762.

Smith, Theobald (1918) A Pleomorphic Bacillus from Pneumonic Lungs of Calves Simulating Actinomyces. J. exp. Med. 28: 333-344.

Sneath, P.H.A. (1956) Conservation of the Generic Name Chromobacterium and Designation of Type Species and Type Strains - Request for an Opinion. Intern. Bull. Bact. Nomen. and Taxon, 6: 65-91.

St. John, Harold (1958) Nomenclature of Plants. A T ext for the Application by the Case Method of the International Code of Botanical Nomenclature. The Ronald Press Co., New York. 1-157.

St. John-Brooks, R. (1931) The Aerobic Actinomyces, in Bulloch, W., Leonard Colebrook, F. Griffith, and R. St. John-Brooks. Med. Res. Coun,, A System of Bacteriology in Relation to Medicine. $\underline{8}$ : $72-78$.

Standley, Paul C. (1916) Tidestromia, a new generic name. J. Wash. Acad. Sci. 6: 69-70.

Stanier, R.Y. (1940) Studies on the Cytophagas. J. Bact. 40: 619-635.

Stewart, Mary Macfarlane (1932) The Bacterial Flora of the Slime and Intestinal Contents of the Haddock (Gadus aeglefinus). J. Mar. biol. Ass. U.K. 18(N.S.): 35-50.

Thirumalachar, M.J. (1955) Chainia, a New Genus of the Actinomycetales. Nature 176: $934-935$.

Thompson, Luther (1933) The Systematic Relationships of Actinobacillus. J. Bact. 26: 221-227.

Tissier, Henry (1900) Recherches sur la Flore Intestinale des Nourrissons. Paris Thèses. 1-253.

Topley, W.W.C. and G.S. Wilson. (1929) The Principles of Bacteriology and Immunity. Edward Arnold and Co., London, lst ed. 1 1300 . 
ed. $\overline{1-1645}$.

(1936) The Principles of Bacteriology and Immunity. 2nd

Trevisan, Vittore (1879) Prime linee d'introduzione allo studio dei Batterj italiani. Second. Comun. Rend. reale ist. lombardo sci. Ser. 2. 12: $133-151$.

- (18ㄷa) Perseveranza dell' 11 luglio 1884, n. 8885 (according to Trevisan 1885a, 84); I microbi del cholera. Perseveranza, num. 8885 [11 luglio 1884] (according to de Toni 1897, 1344).

- (1884b) Gazz. med, ital. - Lombardia, 1884, num. 42 (according to Trevisan $1885 \mathrm{~b}, 95)$; Il Batterio del cholera è un Vibrione, non un Bacillo; è agente esogeno e causa occasionale della malattia, non agente endogeno e causa assoluta. Gazz. med. ital., Lombardia, 1884, num. 42 (according to de Toni 1897, 1344).

- (1885a) Il fungo del choléra asiatica Questioni risolte. Atti Accad. fis. -med. -stat. Milano. Ser. 4. 3: 78-91.

- (1885b) Caratteri di alcuni nuovi generi di Batteriacee. Arii

Accad. fis. -med. -stat. Milano. Ser. 4. 3: 92-106.

- (1887) Sul Micrococco della rabbia e sulla possibilità di riconoscere durante il periodo d'incubazione, dall' esame del sangue della persona morsicata, se ha contratta l'infezione rabbica. Rend. reale ist. lombardo sci. Ser. II. 20: 88-105.

- (1888) Sui Batteri spettanti al genere KLEBSIELLA. Rend.

reale ist. lombardo sci. Ser. II, 21: 777-790.

- (1889a) I Generi e le Specie delle Batteriacee. Milan. 1-35.

- (1889b) in de Toni, J.B. and Trevisan, V., in Saccardo, P.A. Syl1. fung. $8: \overline{9} 23-1087$.

Tsiklinsky, P. (1898) Sur les Microbes Thermophiles. Ann. Microg. 10: $286-288$.

. (1899) Sur les Mucédinées Thermophiles. Ann. Inst. Pasteur 13: 500-505.

Tulasne, R. and J. Brisou. (1955) Les Pleuropneumoniales - Taxonomie des Pleuropneumonia like Organisms et des Formes L. Ann. Inst. Pasteur 88: 237-239.

Turner, A. W. (1935) A Study of the Morphology and Life Cycles of the Organism of Pleuropneumonia contagiosa boum (Borrelomyces peripneumoniae Nov. Gen.) by Observation in the Living State under Dark-Ground Illumination. J. Path. Bact. 41: 1-32.

Ucke, Alexander (1898) Ein Beitrag zur Kenntnis der Anaëroben. Zbl. Bakt., Abt. 1, 23: 996-1001.

Unna, P.G. (1887) Die Rosaniline und Pararosaniline. (Eine Bakteriologische Farbenstudie.) Derm. Stud., Hamburg 4: 1-73.

- (1892) Der Streptobacillus des weichen Schankérs. Mh. prakt. Derm. 14: 485-490.

- (1895a) Die verschiedenen Phasen des Streptobacillus ulceris mollis. Mh. prakt. Derm. 21: 61-81.

- (1895b) Sulle diverse fasi che ha subito la dottrina dello Streptobacillus ulceris mollis. Giorn. ital. Mal, vener. 30: 275-294. 
van Laer, Henri (1892-1895) Contributions a 1'Histołre des Ferments des Hydrates de Carbone (Bacille des Bières Tournées). Acad. R. Sci., Lett. et Beaux-Arts Belg. (Mém. Cour. et Autr. Mém.) 47: 1-37. van Niel, C.B. (1928) The Propionic Acid Bacteria. Haarlem. 1-187. van Steenberge, Paul (1920) Les Proprietés des Microbes Lactiques; leur Classification. Ann. Inst. Pasteur 34: 803-870.

Veillon and Zuber. (1898) Recherches sur Quelques Microbes Strictement Anaérobies et leur Role en Pathologie. Arch. Méd. exp. 10: $517-545$.

Verdun. (1912) Précis Parasitol. (according to Dodge 1935, 741). von Freudenreich, Ed. and S. Orla-Jensen (1907) Ueber die im Emmentalerkăse stattfindende Propionsäuregärung. Zbl. Bakt., Abt. 2, 17: 529-546.

von Tubeuf, Karl Freiherr and William G. Smith. (1897) Diseases of Plants Induced by Cryptogamic Parasites. Longmans, Green and Co., New York. 1-598.

Vuillemin, Paul (1888) Les Tubercules Radicaux des Légumineuses. Ann. Sci. agron., Paris 5(I): 121-212. 527.

(1913) Genera Schizomycetum. Ann. mycol., Berl. 11: 512-

- (1931) Les Champignons Parasites et les Mycoses de 1'Homme. Encyclopédie Mycologique, II. Paul Le Chavalier and Sons, Paris. $1-290$.

Waksman, Selman A. (1940) On the Classification of Actinomycetes. J. Bact. 39: 549-558.

- (1957) Family II, Actinomycetaceae Buchanan and Family III, Streptomycetaceae Waksman and Henrici. in Breed et al., Bergey's Manual of Determinative Bacteriology. The Williams and Wilkins Co., Baltimore. 7th ed. 713-825.

- (1959a) Factors to be Considered in the Classification of Actinomycetes. Intern. Bull. Bact. Nomen. and Taxon. 9: 73-78.

- (1959b) The Actinomycetes. 1: Nature, Occurrence, and Activities. The Williams and Wilkins Co., Baltimore. 1-327.

and Arthur T. Henrici. (1943) The Nomenclature and Classification of the Actinomycetes. J. Bact. 46: 337-341.

. (1948, Jan.) Family Actinomycetaceae Buchanan and

Family Streptomycetaceae Waksman and Henrici. in Breed et al. . Bergey's Manual of Determinative Bacteriology. The Williams and Wilkins Co., Baltimore. 6th ed. 892-980.

Wallroth, Fred. Guil. (1831-33) Flora Cryptogamica Germaniae. Algues et Champignons. 2: 182 .

Watson, Sereno (1880) Botany of California. (Uniform with the publications of the) Geological Survey of California. John Wilson and Son, University Press, Cambridge, Mass. 2: 1-559.

Weichselbaum, A. (1886) Ueber die Aetiologie der acuten Lungen- und Rippenfellentzthdungen. Med. Jb., Wien 82(Heft viii): 483-554. 
Weigmann. (1910) in Wolff, A., Milchwirtschaftliche Bakteriologie. Zbl. Bakt., Abt. $\overline{2}$, 28: 417-422.

Welsch, M. (1959) "Discussion" following Waksman, Selman A. The Classification of Actinomycetes with Special Reference to Antibiotic Producation. Proc. IV Int. Congr. Biochem. $\underline{5}$ (Symposium V: Biochemistry of Antibiotics): 18-19.

Winogradsky, S. (1892) Contributions à la morphologie des organismes de la nitrification. Arch. Sci. biol., St. Petersb. 1: 87-137.

- (1929) Études sur la Microbiologie du Sol - Sur la Dégradation de la Cellulose dans le Sol. Ann. Inst. Pasteur 43: 549-633.

Winslow, C. -E. A., Jean Broadhurst, R.E. Buchanan, Charles Krumwiede, Jr., L. A. Rogers and George H. Smith. (1917) The Families and Genera of the Bacteria. Preliminary Report of the Committee of the Society of American Bacteriologists on Characterization and Classification of Bacterial Types. J. Bact. 2: 505-566.

_________________________ (1920) The Families and Genera of the Bacteria. Final Report of the Committee of the Society of American Bacteriologists on Characterization and Classification of Bacterial Types. J. Bact. 5: 191-229.

Wollenweber, H.W. (1921) Zür Systematisierung der Strahlenpilze. (Gattung Actinomyces Harz.) Ber. dtsch. bot. Ges. 39: (26)-(30).

Wroblewski, Wincenty (1931) Morphologie et Cycle Évolutif des Microbes de la Péripneumonie des Bovides et de 1'Agalaxie Contagieuse des Chèvres et des Moutons. Ann. Inst. Pasteur 47: 94-115.

Zettnow, E. (1915) Einige neue Bakterien. Zbl. Bakt., Abt. 1, Orig. 77: 209-234.

Zimmermann. (1880) Abstracter of: "Bergonzini, Curzio, Sopra un nuovo bacterio colorato. [Ueber ein neues gefärbtes Bacterium.] (Annuario della Soc. dei Naturalisti in Modena. Anno xiv. 1880. Disp. 3a, Ser. Ila, p. 149-158.)." Bot. Zbl. $\underline{4}($ No. 49/50): 15281530.

Zopf, W. (1883) Die Spaltpilze. Eduard Trewendt, Breslau. 1-100.

(1884) Die Spaltpilze. Eduard Trewendt, Breslau. 2nd ed. 1101 .

- (1885) Die Spaltpilze. Eduard Trewendt, Breslau. 3rd ed. 1-127. 